\title{
Liang Fung
}

Detecção fenotípica e genotípica de carbapenemases em isolados de hemoculturas de Pseudomonas aeruginosa e Acinetobacter spp.

Dissertação apresentada à Faculdade de Medicina da Universidade de São Paulo para obtenção do título de Mestre em Ciências

Programa de Doenças Infecciosas e Parasitárias Orientadora: Prof ${ }^{a}$. Dra . Silvia Figueiredo Costa

\author{
São Paulo
}


Dados Internacionais de Catalogação na Publicação (CIP)

Preparada pela Biblioteca da

Faculdade de Medicina da Universidade de São Paulo

Creprodução autorizada pelo autor

Fung, Liang

Detecção fenotípica e genotípica de carbapenemases em isolados de hemoculturas de Pseudomonas aeruginosa e Acinetobacter spp / Liang Fung. -- São Paulo, 2013.

Dissertação(mestrado)--Faculdade de Medicina da Universidade de São Paulo.

Programa de Doenças Infecciosas e Parasitárias.

Orientadora: Silvia Figueiredo Costa.

Descritores: 1.Pseudomonas aeruginosa 2.Acinetobacter 3.Carbapenêmicos 4.Beta-lactamases

USP/FM/DBD-069/13 
Aos meus pais, Luiz e Alice pelo incentivo e amor. 


\section{AGRADECIMENTOS}

À Dra. Silvia Figueiredo Costa, pela orientação, apoio, paciência, amizade e por toda dedicação prestada para realização deste trabalho.

À amiga Inneke van der Heijeden, pelo incentivo, apoio, amizade e pela colaboração durante todas as etapas da realização deste trabalho.

À amiga Andréia Alcaia, pelo incentivo e apoio nos momentos mais difíceis.

A todos os amigos e colegas do Laboratório de Investigação Médica (LIM54) do Hospital das Clínicas da Faculdade de Medicina da Universidade de São Paulo, pelo apoio e incentivo.

Aos amigos Anna Karina Mostachio e Jorge Paez, pela colaboração prestada nesse trabalho e pela amizade.

Aos amigos e colegas do Hospital Israelita Albert Einstein, pelo apoio e amizade.

Aos amigos Mauro Cintra Giudice, Jessika Zerbini e Camila Rizek, pelo apoio e incentivo.

Ao Dr. Jorge Sampaio pelo incentivo e apoio para realização deste trabalho e pelas sugestões propostas no exame de qualificação.

À Dra. Marinês Martino pelo incentivo e sugestões propostas no exame de qualificação.

As amigas Andrea Pereira e Letícia Cavalcanti pelo apoio e amizade.

À minha família, pelo incentivo, apoio e carinho. 
Está dissertação está de acordo com:

Referências: adaptado da International Committee of Medical Journals Editors (Vancouver)

Universidade de São Paulo, Faculdade de Medicina, Serviço de Biblioteca e Documentação. Guia de apresentação de dissertações, teses e monografias.

Elaborado por Annelise Carneiro da Cunha, Maria Julia de A. L. Freddi, Maria F. Crestana, Marinalva de Souza Aragão, Suely Campos Cardoso, Valéria Vilhena. São Paulo: Serviço de Biblioteca e Documentação; $3^{\text {a }}$ edição; 2011.

Abreviaturas dos títulos dos periódicos de acordo com List of Journals Indexed in Index Medicus. 


\section{SUMÁRIO}

Lista de Tabelas

Lista de Quadro

Lista de Figuras

Lista de Abreviaturas

RESUMO

SUMMARY

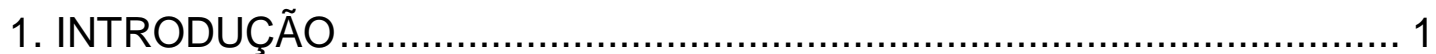

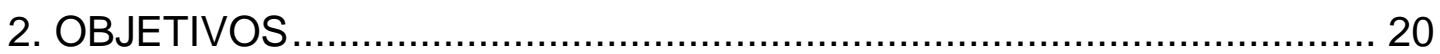

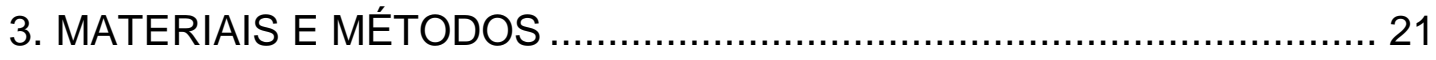

3.1 Amostras bacterianas........................................................... 21

3.2 Protocolo para determinação dos halos de inibição (método de difusão de disco ou método de Kirby-Bauer) ............................................. 21

3.3 Microdiluição em caldo .......................................................... 22

3.4 Detecção de Metalo- $\beta$-lactamase pelo método do Etest ${ }^{\circledR}$ (AB Biodisk

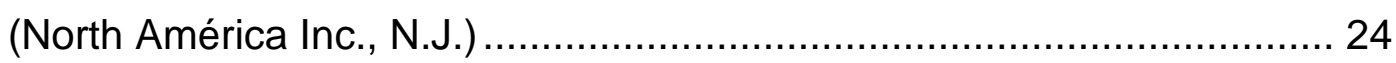

3.5 Detecção Metalo- $\beta$-lactamase pelo método de Arakawa et al. (2000) modificado (Teste do duplo disco sinergismo -DDST- e Disco combinado CD)

3.6 Detecção de Carbapenemases pelo método de Hodge modificado (Lee et al., 2001) 26

3.7 Avaliação do método com disco de ácido borônico para detecção de carbapenemases

3.8 Análise sensibilidade e especificidade dos testes fenotípicos 27

3.9 Hidrólise 28

3.10 Detecção de genes codificadores para $\beta$ - lactamase ...................... 29

3.10.1 Extração de DNA ..................................................... 29

3.10.2 Reação de amplificação em cadeia da polimerase (PCR) para detecção de genes de resistência ............................................ 29

3.11 Reação de sequenciamento .................................................... 31

3.12 Protocolo para Tipagem Molecular............................................ 31

3.13 Fluxograma das atividades..................................................... 35 


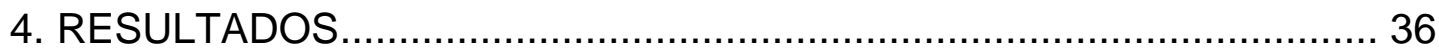

4.1 Amostras bacterianas........................................................... 36

4.2 Perfil de sensibilidade .............................................................. 37

4.3 Reações de amplificação em cadeia da polimerase (PCR)............... 38

4.3.1 Reação de amplificação em cadeia da polimerase (PCR) multiplex para detecção de genes codificadores de Metalo- $\beta$-lactamase ............ 38

4.3.2 Reação de amplificação em cadeia da polimerase (PCR) para oxacilinases

4.3.3 Reação de amplificação em cadeia da polimerase (PCR) para outras carbapenemases

4.3.4 Reação de amplificação em cadeia da polimerase (PCR) para gene codificador intl-1

4.4 Análise do polimorfismo do DNA por eletroforese em campo pulsado (PFGE)

4.5 Detecção fenotípica de Metalo- $\beta$-lactamase pelo método do Etest ${ }^{\circledR} .46$ 4.6 Detecção fenotípica de Metalo- $\beta$-lactamase pelo método de aproximação de disco 48

4.7 Detecção de Carbapenemases pelo método de Hodge modificado (Lee et al., 2001) 50

4.8 Avaliação do método de detecção de carbapenemase com ácido borônico 51

4.9. Hidrólise do Imipenem ................................................. 53

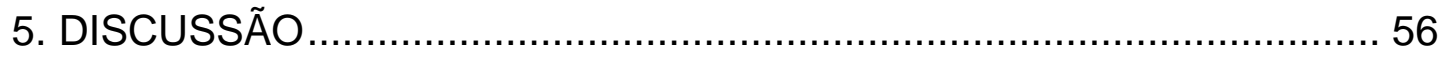

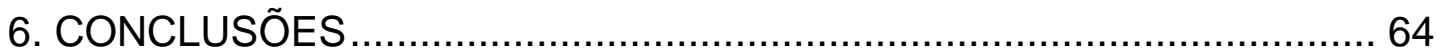

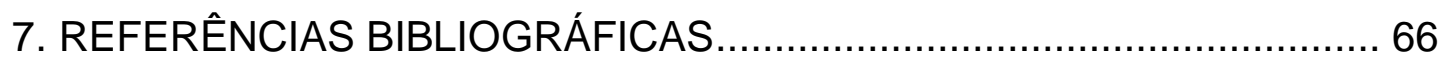

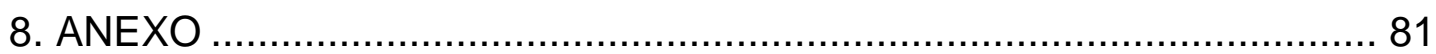




\section{Lista de Tabelas}

Tabela 1 - Sequência de primers utilizados para as reações de PCR

Tabela 2 - Condições de corrida para PFGE

Tabela 3 - Critérios interpretativos para análise de tipagem molecular

Tabela-4 - Porcentagem cumulativa das CIMs para os isolados de $P$. aeruginosa e Acinetobacter spp. em relação aos antimicrobianos imipenem e meropenem

Tabela 5 - Resultados da concentração inibitória mínima (CIM) dos isolados e o tipo de gene codificador $\mathrm{M} \beta \mathrm{L}$

Tabela 6 - Relação entre os perfis de sensibilidade para imipenem (IMP) e meropenem (MERO) para os genes codificadores de M $\beta L$ e oxacilinases em isolados de Acinetobacter spp.

Tabela 7 - Resultados da concentração inibitória mínima (CIM) dos isolados de $P$. aeruginosa positivos para o gene GES

Tabela 8 - Resultados das CIMs de imipenem e meropenem dos isolados de Pseudomonas aeruginosa e presença dos genes codificadores de carbapenemases e a presença do gene intl1

Tabela 9 - Análise molecular dos 108 isolados de P. aeruginosa multirresistentes, realizada de acordo com critérios propostos por Tenover et al. (1995)

Tabela 10 - Análise molecular dos 50 isolados de Acinetobacter spp, realizada de acordo com critérios propostos por Tenover et al. (1995)

Tabela 11 - Comparação entre a metodologia de Etest ${ }^{\circledR}$ com o padrão ouro (PCR) para isolados de Acinetobacter spp e $P$. aeruginosa positivos para 0 gene $M \beta L$

Tabela 12 - Comparação entre a metodologia de Etest ${ }^{\circledR}$ com o padrão ouro (PCR) para isolados de Acinetobacter spp positivos para os genes oxacilinases 
Tabela 13 - Comparação de duas técnicas fenotípicas com a medotologia padrão ouro - PCR para a detecção da produção de $\mathrm{M} \beta \mathrm{L}$ em isolados de $P$. aeruginosa e Acinetobacter spp.

Tabela 14 - Resultados do teste do Hodge modificado dos 158 isolados de $P$. aeruginosa e Acinetobacter spp.

Tabela 15 - Sensibilidade e especificidade (\%) do ácido fenilborônico com o ácido aminofenilborônico dos 158 isolados de Pseudomonas aeruginosa / Acinetobacter spp.

Tabela 16- Comparação do teste de hidrólise com outras técnicas fenotípicas para detecção de carbapenemase dos 49 isolados de $P$. aeruginosa

Tabela 17- Comparação do teste de hidrólise com outras técnicas fenotípicas para detecção de carbapenemases dos 23 isolados de Acinetobacter spp. 


\section{Lista de Quadro}

Quadro 1 - Classificação de $\beta$-lactamases segundo Bush et al., 2010 


\section{Lista de figuras}

Figura 1- Disseminação no mundo dos diferentes tipos de MßLs

Figura 2 - Gráfico ilustrativo da distribuição das 108 amostras de $P$. aeruginosa de acordo com o ano de isolamento

Figura 3 - Gráfico ilustrativo da distribuição das 50 amostras de Acinetobacter spp. de acordo com o ano de isolamento

Figura 4 - Gel de eletroforese - Multiplex PCR para detecção dos genes de $M \beta L$ isolados de $P$. aeruginosa

Figura 5 - Representação do perfil de bandas obtidos a partir do método PFGE em isolados $P$. aeruginosa após utilização da enzima Spe-I

Figura 6 - Representação do perfil de bandas obtido a partir do método de eletroforese em campo pulsado, utilizando-se a enzima de restrição Smal em amostras de Acinetobacter spp.

Figura 7 - Determinação da concentração inibitória mínima e detecção Metalo- $\beta$-lactamase por fita de Etest ${ }^{\circledR}$ de uma amostra clínica de $P$. aeruginosa

Figura 8 - Teste de aproximação de disco imipenem com os inibidores e comparação da diferenciação de halo do disco IMI com I+E

Figura 9 - Teste de aproximação de disco ceftazidima com os inibidores EDTA e ABM 


\section{Lista de abreviaturas}

AAB - Ácido Aminofenilborônico

ABM - Ácido $\beta$-mercaptoetanol

AFB - Ácido Fenilborônico

CAZ - Ceftazidima

CD - Teste disco combinado

CIM - Concentração inibitória mínima

CLSI - Clinical and Laboratory Standards Institute

CVE - Centro de Vigilância Epidemiológica

DDST - Teste duplo disco por sinergismo

DPT - Teste de disco potenciação

EDTA - Ácido Etilenodiamino Tetra-Acético

ESBL - Beta Lactamase de Espectro Estendido

HC-FMUSP - Faculdade de Medicina da Universidade de São Paulo do Hospital das Clínicas

ICARE - Projeto de vigilância

IMI - Imipenem

LIM-54 - Laboratório de Investigação Médica - 54

MERO - Meropenem

MHCA - Müeller Hinton cátion ajustado 
MHT - Teste de Hodge Modificado

MPA - 2-mercaptopropiônico

M $\beta L$ - Metalo- $\beta$-lactamase

OXA - Oxacilinase

PCR - reação em cadeia da polimerase

PFGE - Eletroforese em campo pulsado

SCOPE - Estudo de Vigilância e Controle de Patógenos de Importância Epidemiológica

SENTRY - Estudo de vigilância de resistência a antimicrobianos envolvendo centro médico de todo mundo

UTI - Unidade de Terapia Intensiva 


\section{RESUMO}

FUNG. L. Detecção fenotípica e genotípica de carbapenemases em isolados de hemoculturas de Pseudomonas aeruginosa e Acinetobacter spp. São Paulo, 2013. Dissertação de mestrado. Programa de Doenças Infecciosas e Parasitárias, Faculdade de Medicina da Universidade de São Paulo.

A resistência aos carbapenêmicos em amostras de Pseudomonas aeruginosa e Acinetobacter spp aumentou na última década. Vários surtos causados por esses agentes já foram descritos no Brasil. O presente estudo comparou métodos fenotípicos de triagem de carbapenemase em $P$. aeruginosa e Acinetobacter spp. isolados de hemoculturas de pacientes internados no HC-FMUSP. Foram estudados 108 isolados de $P$. aeruginosa identificados por sistema automatizado Vitek $^{\circledR}$ e 50 isolados Acinetobacter spp. identificados pelo método miniaturizado API20NE. A determinação inibitória mínima dos carbapenêmicos foi realizada pela técnica de microdiluição em caldo e a tipagem molecular pela técnica de eletroforese em campo pulsado (PFGE). Os genes codificadores de carbapenemase foram identificados por meio da técnica de reação em cadeia da polimerase (PCR) e foi avaliada a hidrólise de imipenem de todos os isolados positivos para esses genes. Sensibilidade, especificidade, valor preditivo negativo e positivo dos testes fenotípicos foram calculados usando como padrão-ouro a detecção dos genes codificadores das carbapenemases por PCR. Nos isolados de Acinetobacter spp, foram pesquisados os genes das oxacilinases, dos quais quarenta e nove (98\%) apresentaram pela técnica de PCR genes codificadores da enzima Oxa-51-like, sendo que um isolado não apresentou essa enzima e após sequenciamento do gene codificador da porção 16S do RNA ribossomal, foi considerado da espécie $A$. calcoaceticus. Em trinta e oito (76\%) dos isolados foi detectado o gene blaoxA-143, em nove (18\%) foi detectado o gene blaOXA-23, sendo que sete desses isolados 
pertenciam ao mesmo clone. Apenas cinco (10\%) isolados de Acinetobacter spp apresentaram o gene bla|MP-1. Para os isolados de $P$. aeruginosa o gene bla SPM- $1_{\text {foi }}$ o mais frequente sendo identificado em vinte e um $(19,4 \%)$ dos isolados e quatro $(3,7 \%)$ foi identificado com o gene blaviM-2. Nove dos vinte

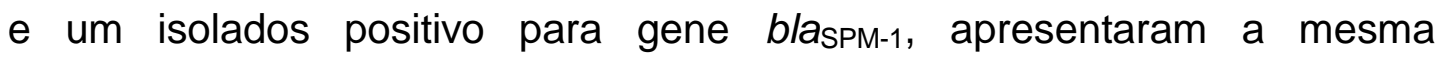
clonalidade. O gene codificador bla GES-5 $_{5}$ foi encontrado em quatro $(3,7 \%)$ dos isolados de $P$. aeruginosa. Dos vinte quatro isolados $P$. aeruginosa que apresentaram gene codificador da $\mathrm{M} \beta \mathrm{L}$, apenas um isolado não hidrolisou IMI entre os Acinetobacter spp e apenas dois dos cincos isolados positivos para o gene codificador de $\mathrm{M} \beta \mathrm{L}$, hidrolisaram o IMI e apresentaram inibição com o EDTA. Dos vários testes fenotípicos realizados, os melhores resultados foram observados com Etest ${ }^{\circledR} \mathrm{M} \beta \mathrm{L}$ para ambos microrganismos com sensibilidade de $100 \%$, mas esse teste foi pouco específico. Para os isolados de Acinetobacter spp o melhor resultado foi observado com o teste de aproximação de disco de IMI com disco de ABM, que apresentou sensibilidade de $100 \%$ e especificidade de $71 \%$ e para $P$. aeruginosa foi a aproximação de disco de CAZ com um disco de EDTA, que apresentou sensibilidade de $48 \%$ e especificidade de $93 \%$. O presente estudo verificou que não existe um único teste fenotípico que consiga identificar carbapenemases nesses isolados e que a performace dos testes varia de acordo com as carbapenemases encontradas.

Descritores: Pseudomonas aeruginosa, Acinetobacter, carbapenêmicos, Beta-lactamases. 


\section{SUMMARY}

Fung L. Phenotypic and genotypic detection of carbenemases in isolates from blood cultures of Pseudomonas aeruginosa and Acinetobacter spp. São Paulo, 2013. Dissertation of the masters, Program of Infectious and Parasitic Diseases, Faculty of Medicine, University of São Paulo.

Carbapenem resistance in Pseudomonas aeruginosa and Acinetobacter spp increased in the last decade. Several outbreaks caused by these agents resistant to carbapenems have been reported in Brazil. This study compared several phenotypic methods for screening of carbapenemase in $P$. aeruginosa and Acinetobacter spp isolated from blood cultures of hospitalized patients in HCFMUSP. One hundred and eight isolates were studied of $P$. aeruginosa identified by the automated system Vitek $\circledast$ and fifty isolates Acinetobacter spp identified by the API20NE method miniaturized. The determination of cabapenem minimum inhibitory was performed by the microdilution broth. Molecular typing was performed using the technique of pulsed field gel electrophoresis (PFGE). Genes encoding carbapenemase were identified by the technique of polymerase chain reaction (PCR) and was evaluated by hydrolysis of imipenem of all the positives isolates. Sensitivity, specificity, positive and negative predictive value of phenotypic tests were calculated using as the gold standard the detection of genes encoding carbapenemases by PCR. Oxacilinases genes were evaluated in isolates of Acinetobacter spp, of which forty-nine (98\%) exhibited by PCR enzymeencoding gene OXA-51-like, and the one isolate that did not show this enzyme, after gene sequencing encoding portion $16 \mathrm{~S}$ ribosomal RNA was considered the species $A$. calcoaceticus. In thirty-eight $(76 \%)$ isolates the gene OXA-143like was detected and seven belonged to the same clone. Only five (10\%) isolates of Acinetobacter spp showed the gene bla|MP-1. For the isolates of $P$. aeruginosa, gene blasPM-1 was the most frequent being present in twenty-one 
$(19,4 \%)$ isolates and four $(3,7 \%)$ was identified with the gene blaviM-2. Nine of the twenty-one isolates positive for gene blasPM-1, showed the same clonality. The gene encoding bla $a_{\mathrm{GES}-5}$ was found in four $(3,7 \%)$ isolates of $P$. aeruginosa. Among the twenty-four isolates $P$. aeruginosa harboring $M \beta L$, not only one isolated hydrolyzed IMI, between Acinetobacter spp two of five isolates harboring M $\mathrm{ML}$ hydrolyzed IMI that was inhibited by EDTA. Of the various phenotypic tests conducted, the best results were observed for Etest $^{\circledR}$ for both micro-organisms with sensitivity $100 \%$, but this test was not specific. For the isolates of Acinetobacter spp best result was observed in the nearest IMI disk a disk of $A B M$, which had a sensitivity of $100 \%$ and specificity of $71 \%$ and for $\mathrm{P}$. aeruginosa was approaching CAZ disk with a disk EDTA which had a sensitivity of $48 \%$ and specificity of $93 \%$. This study verified that there is no single phenotypic test which can identify those isolates carbapenemases and that the performance of the tests various according to carbapenemases found.

Descriptors: Pseudomonas aeruginosa, Acinetobacter, carbapenems, Betalactamases. 


\section{INTRODUÇÃO}

Pseudomonas aeruginosa e Acinetobacter baumannii são bacilos Gram-negativos não fermentadores, considerados importantes agentes de infecção hospitalar. Na última década houve um aumento significativo das infecções hospitalares causadas por $P$. aeruginosa e $A$. baumannii resistentes aos carbapenêmicos em todo, mundo principalmente na Europa e na América Latina, e especial no Brasil (Walsh et al., 2002). Dados do programa do estudo SENTRY (estudo de vigilância de resistência a antimicrobianos envolvendo centros médicos em todo o mundo) de isolados de bactérias de oito hospitais no Canadá, 30 hospitais nos Estados Unidos da América e 10 hospitais na América Latina mostram que $P$. aeruginosa foi o terceiro agente isolado de infecção de corrente sanguínea e que os isolados da América Latina foram mais resistentes a todas as classes de antimicrobianos (Diekema et al., 1999).

Vários estudos SENTRY avaliaram dados de resistência destes patógenos na última década (Tognim et al., 2006; Gales et al., 2011; Gales et al., 2012). Um estudo avaliou isolados de infecções da corrente sanguínea, trato respiratório inferior, pele, tecido mole e trato urinário coletadas em países da América Latina entre eles: Argentina (1997-2001); Brasil (1997-2001); Chile (1997-2001); Colômbia (1997-2000); México (19972001); Uruguai (1997) e Venezuela (1998-2001). Esse estudo avaliou 826 isolados de Acinetobacter spp, o Brasil foi o que contribuiu com maior número de amostras $(\mathrm{n}=400)$. Entre os isolados, a maioria foi identificada como A. baumannii e A. calcoaceticus. A sensibilidade aos carbapenêmicos encontrada nesse estudo foi bastante elevada, sendo $86,8 \%$ de sensibilidade para meropenem e $86,9 \%$ para imipenem. Entretanto, observou-se uma diminuição significativa da sensibilidade aos carbapenêmicos ao longo do período do estudo (Tognim et al., 2006). 
Outro estudo SENTRY avaliou a atividade antimicrobiana da colistina e da polimixina $B$ e de outros antimicrobianos de uma coleção mundial de 40.625 bacilos Gram-negativos. As polimixinas mostraram uma potente atividade in vitro $\left(\mathrm{MIC}_{90}, \leq 0,5-1 \mathrm{mg} / \mathrm{L}\right)$ contra essa coleção de isolados clínicos, com proporção de resistência muito baixa (de 0,1\%-1,5\%). Embora tenha demostrado uma excelente atividade in vitro para a maioria dos bacilos Gram-negativos, uma tendência de resistência foi observada na região da Ásia-Pacifico e América Latina (Gales et al., 2011).

Finalmente, um estudo SENTRY mais recente analisou 12.811 isolados bacterianos, incluindo 5,704 bacilos Gram-negativos $(44,5)$ no período de janeiro de 2008 a dezembro de 2010 a partir de 10 centros médicos localizados na Argentina, Brasil, Chile e México. O Brasil apresentou maior proporção Klebsiella spp. resistente ao meropenem $(11,1 \%)$, a produção de KPC não foi detectada em 2008, mas surgiu em 2009 (10 cepas) e aumentou significativamente em 2010. A proporção de $P$. aeruginosa resistente ao meropenem foi de $46,7 \%$ no Brasil. A resistência do Acinetobacter spp. ao imipenem aumentou de 12,6\% no ano de 1997-1999 para 71,4\% no ano 2008-2010. A presença de oxacilinases em Acinetobacter spp. foi documentada na Argentina (OXA-23 e OXA-24), Brasil (OXA-23), Chile (OXA-58) e México (OXA-24) (Gales et al., 2012).

Surtos de infecções hospitalares causados por $A$. baumannii e $P$. aeruginosa resistentes aos carbapenêmicos vêm sendo descritos na literatura. No Brasil, já foram reportados surtos de infecção hospitalar por $A$. baumannii e $P$. aeruginosa resistentes aos carbapenêmicos, em São Paulo desde o início da década de 90 (Levin et al., 1996). Foi evidenciada também, a transmissão de isolados de $A$. baumannii resistentes aos carbapenêmicos caracterizados por tipagem molecular entre hospitais na cidade de São Paulo (Sader et al., 1996).

Gales e colaboradores (2012) mostraram em um estudo SENTRY, mais recente, realizado em vários países da América Latina, inclusive o Brasil, que contribuiu com $40,9 \%$ de bactérias Gram-negativas, sendo a 
maioria de infecções de corrente sanguínea (52,6\%), que $P$. aeruginosa foi o terceiro agente mais identificado (13,8\%) e o Acinetobacter spp. $(9,9 \%) \circ$ quinto.

O estudo de Vigilância e Controle de Patógenos de Importância Epidemiológica (SCOPE) que inclui dados de cinco regiões geográficas mostrou a importância da prevalência de infecções por bactérias Gramnegativas no Brasil, especialmente quando no que diz respeito ao tratamento empírico de infecções de corrente sanguínea. A resistência aos antibióticos é preocupante, particularmente em isolados de $P$. aeruginosa e $A$. baumannii, que apresentam taxas elevadas de resistência aos carbapenêmicos respectivamente $35 \%$ e $56 \%$. Essas taxas estão entre as mais altas na literatura e tem várias implicações para prática clínica (Marra, et al., 2011).

Segundo os dados do Centro de Vigilância Epidemiologica (CVE) nos anos de 2005 à 2010 a resistência de amostras de A. baumannii ao imipenem aumentou e foi de $75,3 \%$ e de $P$. aeruginosa foi de $5,2 \%$ no estado de São Paulo. No ano de 2011 foram isolados 13.013 microorganismos de pacientes com infecção de corrente sanguínea, 949 (7,3\%) eram infectados por $A$. baumannii com resistência aos carbapenêmicos e $324(2,5 \%)$ por $P$. aeruginosa.

Dados brasileiros do SCOPE demonstraram que infecções hospitalares de corrente sanguínea são uma importante causa de morbidade e mortalidade. Esse estudo incluiu 2.563 pacientes com infecção de corrente sanguínea, de 2007 à 2010, e mostrou que 95\% das infecções foram monomicrobianas, e que $58,5 \%$ foram causadas por bacilos Gram-negativos, $35,4 \%$ por Gram-positivos e 6,1\% por fungos. Os isolados de Acinetobacter spp. e $P$. aeruginosa correspondiam a $55,9 \%$ e $36,8 \%$ respectivamente resistentes ao imipenem (Marra, et al. 2011).

Outro estudo realizado por Girão e colaboradores (2008) no Hospital das Clínicas da Universidade de São Paulo (HC-FMUSP) caracterizou a 
evolução dos agentes de infecções de corrente sanguínea em unidades de terapia intensiva (UTI) e os fatores de risco associados com mortalidade. A taxa de mortalidade global foi de $38 \%$, os resultados mostraram predominância de Gram-negativos, com um aumento significativo na incidência de $A$. baumannii e $K$. pneumoniae ao longo do tempo. Acinetobacter spp têm sido particularmente um problema nos hospitais da América Latina, com uma alta taxa de resistência (Girão, 2008).

Outro estudo realizado no transplante de células troncos e unidades de hematologia HC-FMUSP avaliou amostras de $P$. aeruginosa resistentes aos carpabenêmicos do período de Janeiro 2006 à Março de 2009 e constatou a presença do gene bla $\mathrm{SPM}^{-1}$ e a presença do blavIM-2, esse surto foi o primeiro a relatar a presença desses genes em unidades de transplante de células tronco (Paez,et al., 2011).

\section{Mecanismos de resistência}

Os mecanismos de resistência aos $\beta$-lactâmicos mais comumente descritos nesses agentes são alteração da membrana externa, produção de $\beta$-lactamase, efluxo e alteração no sítio de ação dos $\beta$-lactâmicos (Kohler et al., 1999; Okamoto et al., 2001; Okamoto et al., 2002, Vella et al., 2011).

\section{Alteração de membrana externa}

Os Gram-negativos possuem uma membrana externa constituída por proteínas e canais hidrofílicos denominados porinas. A membrana externa funciona como uma barreira à penetração dos antimicrobianos. Os $\beta$ lactâmicos precisam cruzar a membrana externa para se ligaram às PBPs (proteínas ligadoras de penicilinas), que são sítios de ação dos $\beta$-lactâmicos situados na face externa da membrana citoplasmática. As PBPs variam em 
número, estrutura e afinidade aos $\beta$-lactâmicos de acordo com a espécie e gênero da bactéria. As porinas também variam em tamanho e número, expressando maior ou menor grau de resistência, além de serem específicas para diferentes antibióticos (Flaherby et al., 1996).

No que diz respeito aos carbapenêmicos, antimicrobianos de largo espectro de ação, utilizados geralmente no tratamento de infecções hospitalares causadas por Gram-negativos resistentes aos outros $\beta$ lactâmicos, os principais mecanismos de resistências são produção de $\beta$ lactamases que hidrolisam os carbapenêmicos, alteração da permeabilidade da membrana externa através de perda de porinas, bomba de efluxo e menos freqüentemente alteração no sítio de ação da droga. (Kohler 1999, Okamoto et al., 2001, Okamoto 2002, Fernandez-Cuenca et al., 2003).

A proteína de membrana externa OprD regula a entrada dos carbapenêmicos, e a perda da função OprD é um dos principais determinante de resistência não-metalo- $\beta$-lactamase mediada pelos carbapenêmicos (Lee et al., 2012)

Limansky et al. (2002) demostraram que a resistência ao imipenem estava associada com a perda de uma proteína de membrana externa CarO (29 Kda), nos isolados clínicos de $A$. baumannii e que nenhuma atividade de enzimas aos carpabenêmicos foi detectada nestes isolados.

Um estudo feito por Del Mar Tomas et al. (2005) com isolados de $A$. baumannii verificou que a resistência elevada aos carbapenêmicos era devido à perda da proteína de membrana externa 33 a 36 kDa.

Mostachio et al (2010) avaliaram três diferentes proteínas de membrana externa (43kDa, 33-36kDa e $29 \mathrm{kDa})$ de vinte seis isolados de $A$. baumanii, mostrando a importância desse mecanismo de resistência. As proteínas de membrana externa CarO $(29 \mathrm{kDa})$, proteínas de $33-36 \mathrm{kDa}$ e $43 \mathrm{kDa}$ estavam diminuídas ou ausentes nos diferentes clones avaliados e três isolados apresentaram total ausência dessas proteínas. 


\section{Bombas de efluxo ou hiperexpressão de sistemas}

O mecanismo de efluxo é expresso em todas as células vivas e tem a função de protegê-las de componentes tóxicos. O aumento da expressão dessas bombas tem sido associado a bactérias multirresistentes (Vila et al., 2007).

Os sistemas de efluxo são normalmente formados por proteínas de membrana especializadas, que podem ser divididas de acordo com sua função em: i) bomba de efluxo de membrana interna ou citoplasmática; ii) proteína formadora do canal extrusor na membrana externa; iii) proteína de fusão que liga os outros dois componentes da bomba de efluxo (Nikaido, 1994).

Quatro principais sistemas de efluxo já foram descritos em $P$. aeruginosa: 1) MexAB-OprM; 2) MexCD-OprJ; 3) MexEF-OprN; 4) MexXYOprM, contudo, pelo menos cinco outros sistemas aguardam caracterização (Livermore, 2002). Nos Acinetobacter spp já foram descritas seis famílias de sistemas de efluxo: 1) Major facilitator superfamily (MFS); 2) Adenosine triphosphate-binding cassete superfamily (ABC); 3) Small Multidrug resistance (SMR); 4) Resistance-nodulation-cell division superfamily (RND); 5) Multidrug and toxic compound extrusion family (MATE); 6) Drug/metabolite transporter superfamily (DMT) (Marchand et al., 2004).

A resistência aos carbapenêmicos pode ser devido à inativação de OprD e muitas vezes ocorre em conjunto com outros mecanismos como a expressão AmpC ou MexAB-OprM. O sistema de efluxo, MexAB-OprM está associado a resistência do meropenem, mas não a resistência do imipenem. Os sistemas de efluxo MexCD-OprJ, MexEF-OprN e MexXY-OprM também podem estar envolvidos com a susceptibilidade reduzida ao meropenem. Um estudo da Coréia do Sul mostrou que a expressão diminuiu OprD e superexpressão da MexAB-OprM e AmpC são a principal causa do mecanismo de resistência em isolados de $P$. aeruginosa (Lee et al., 2012). 
A família RND possui um complexo chamado AdeABC que foi 0 primeiro sistema descrito em Acinetobacter spp. e que confere resistência aos aminoglicosídeos, fluoroquinolonas, eritromicina, cefotaxima, clorafenicol, tetraciclina, trimetropim e tigeciclina. E quando associado a presença das oxacilinases podem levar a resistência ao imipenem (Peleg et al., 2008).

Segundo Coyne et al.(2011), o papel da AdeABC na resistência aos carbapenêmicos é controversa. A super expressão da AdeABC contribui para a alto nível de resistência aos carbapenêmicos, notável para imipenem e meropenem, quando associados com carbapenemases.

\section{Alteração das proteínas ligadoras de penicilina (PBPs)}

As PBPs são os sítios alvo para atividade dos antimicrobianos da classe dos $\beta$-lactâmicos. Estes se ligam covalentemente as PBPs impedindo a formação da parede celular e causando a lise osmótica da célula. A resistência aos $\beta$-lactâmicos, devido a alterações nas PBPs, é mais comum em micro-organismos Gram-positivos que em Gram-negativos (Lincopan et al., 2007).

Bellido e colaboradores (1990), demostraram que a resistência aos carbapenêmicos em $P$. aeruginosa estaria associada a alterações na PBP-4. Outros autores mostraram que a resistência aos antimicrobianos carbapenêmicos também podem estar associada com a diminuição da expressão de PBP-2, em isolados de A. baumannii (Gehrlein et al., 1991; Fernandez- Cuenca et al., 2003; Giamarellou et al., 2008). 


\section{Produção de $\beta$-lactamases}

As $\beta$-lactamases são enzimas que hidrolisam o anel $\beta$-lactâmico dos antibióticos, desta maneira destroem o sítio ativo deste antibiótico e impedem sua ação. Caracterizam-se por sua capacidade de hidrolisar determinados subgrupos de $\beta$-lactâmicos e por esta razão em algumas subclassificações são denominadas penicilinases, cefalosporinases ou carbapenemases, dependendo do $\beta$-lactâmicos com maior taxa de hidrólise pela enzima (Bush; Jacoby \& Medeiros, 1995).

Várias classificações das $\beta$-lactamases já foram descritas na literatura, de acordo com sua propriedade funcional e molecular. Na classificação funcional de Bush, Jacoby \& Medeiros (1995), as $\beta$-lactamases dividem-se em quatro grupos que variam de 1 a 4 , e apresentam subgrupos nos grupos 2 e 3 , os quais são diferenciados de acordo com o substrato específico e perfil inibidor. A classificação atual inclui o grupo 1 (classe C) cefalosporinases; grupo 2 (classes A e D) de amplo espectro, inibidorresistência e $\beta$-lactamases espectro estendido e carbapenemases serina (Quadro 1). Leva em conta os perfis de substrato inibidor em uma tentativa de agrupar as enzimas com seu fenótipo em grandes grupos que geralmente se correlacionam com a classificação mais ampla de base molecular, que segundo Ambler e colaboradores (1980), se dividem em A (penicilinasesESBLS, TEM-1, SHV-1, SHV), B (metaloenzimas - MBLs), C e D (oxacilinases- OXAs), baseadas na homologia da sequência dos aminoácidos. O sistema atual inclui o grupo 1 (classe C) cefalosporinases; grupo 2 (classes A e D) de amplo espectro, inibidor resistente e de $\beta$ lactamases espectro estendido e carbapenemases serina e grupo 3 metalo$\beta$-lactamases. Vários novos subgrupos de cada um dos grupos principais são descritas, com base em atributos específicos das enzimas. A nova classificação também é sugerida para a descrição de uma nova $\beta$ lactamase, incluindo as propriedades requeridas microbiológicas, substrato e inibidor de perfis e os dados de seqüências moleculares (Bush \& Jacoby, 2010). 
Quadro 1 - Classificação de $\beta$-lactamases segundo Bush et al., 2010

\begin{tabular}{|c|c|c|c|c|c|c|c|}
\hline \multicolumn{8}{|c|}{$\beta$-lactamases } \\
\hline \multirow{2}{*}{$\begin{array}{l}\text { Bush- } \\
\text { Jacoby } \\
\text { grupo } \\
(2009) \\
\end{array}$} & \multirow{2}{*}{$\begin{array}{c}\text { Bush-Jacoby- } \\
\text { Medeiros grupo } \\
(1995)\end{array}$} & \multirow{2}{*}{$\begin{array}{l}\text { Classe } \\
\text { molecular }\end{array}$} & \multirow[b]{2}{*}{ Substrato } & \multicolumn{2}{|c|}{ Inibidas por } & \multirow[b]{2}{*}{ Características } & \multirow[b]{2}{*}{ Representantes } \\
\hline & & & & $\begin{array}{l}\text { CA ou } \\
\text { TZB }\end{array}$ & EDTA & & \\
\hline 1 & 1 & C & Cefalosporinas & Não & Não & $\begin{array}{c}\text { Maior hidrolise de cefalosporinas que benzilpenicilina; } \\
\text { hidrolizam cefamicinas }\end{array}$ & $\begin{array}{l}\text { E. coli AmpC, MIR-1, ACT-1, FOX- } \\
\text { 1,GC1, CMY-37, CMY-2, P99 }\end{array}$ \\
\hline $1 e$ & $\mathrm{NI}$ & C & Cefalosporinas & Não & Não & $\begin{array}{l}\text { Hidrólise de ceftazidime e muitos outros oxyimino- } \beta \text { - } \\
\text { lactamase }\end{array}$ & GCI, CMY-37 \\
\hline $2 a$ & $2 a$ & A & Penicilinas & $\operatorname{Sim}$ & Não & Maior hidrolise de benzilpenicilina que cefalosporinas & PC1 \\
\hline $2 b$ & $2 b$ & A & $\begin{array}{l}\text { penicilinas, } \\
\text { cefalosporinas }\end{array}$ & $\operatorname{Sim}$ & Não & Hidrólise similares de benzilpenicilina e cefalosporinas & TEM-1, TEM-2, SHV-1 \\
\hline $2 \mathrm{be}$ & $2 \mathrm{be}$ & A & $\begin{array}{l}\text { cefalosporinas espectro } \\
\text { extendido, } \\
\text { monobactams }\end{array}$ & $\operatorname{Sim}$ & Não & $\begin{array}{l}\text { Hidrolisa oxyimino- } \beta \text {-lactamase (cefotaxime, ceftazidime, } \\
\text { ceftriaxone, cefepime, aztreonam) }\end{array}$ & $\begin{array}{l}\text { TEM-3, SHV-2, CTXM-M-15, PER- } \\
\text { 1, VEB-1 }\end{array}$ \\
\hline $2 b r$ & $2 b r$ & A & Penicilinas & Não & Não & Resistência para ácido clavulânico, sulbactam e tazobactam & TEM-30, SHV-10 \\
\hline $2 b e r$ & $\mathrm{NI}$ & A & $\begin{array}{l}\text { cefalosporinas espectro } \\
\text { extendido, } \\
\text { monobactams }\end{array}$ & Não & Não & $\begin{array}{l}\text { Hidrolisa oxyimino- } \beta \text {-lactamase combinado com resistência } \\
\text { para ácido clavulânico, sulbactam e tazobactam }\end{array}$ & TEM-50 \\
\hline 2c & 2c & A & Carbenicilina & Sim & Não & Hidrolisa a carbenicilina & PSE, CARB-3 \\
\hline 2ce & $\mathrm{NI}$ & A & Carbenicilina, cefepime & Sim & Não & Hidrolisa carbenicilina, cefepime e cefpirome & RTG-4 \\
\hline $2 \mathrm{~d}$ & $2 \mathrm{~d}$ & $\mathrm{D}$ & Cloxacilina & Variavel & Não & Hidrolisa cloxacilina ou oxacilina & OXA-1, OXA-10 \\
\hline 2de & $\mathrm{NI}$ & D & $\begin{array}{l}\text { Cefalosporinas } \\
\text { espectro extendido }\end{array}$ & Variavel & Não & Hidrolisa cloxacilina ou oxacilina e oxyimino- $\beta$-lactamase & OXA-11, OXA-15 \\
\hline $2 \mathrm{df}$ & $\mathrm{NI}$ & D & Carbapenens & Variavel & Não & Hidrolisa cloxacilina ou oxacilina e carbapenens & OXA-23, OXA-48 \\
\hline $2 e$ & $2 e$ & A & $\begin{array}{l}\text { Cefalosporinas } \\
\text { espectro extendido }\end{array}$ & Sim & Não & $\begin{array}{l}\text { Hidrolisa cefalosporinas, inibidas pelo ácido clavulânico mas } \\
\text { não aztreonam }\end{array}$ & CepA \\
\hline $2 f$ & $2 f$ & A & Carbapenens & Variavel & Não & Hidrolisa carbapenens, oxyimino- $\beta$-lactamase, cefamicinas & KPC-2, IMI-1, SME-1 \\
\hline \multirow[t]{2}{*}{$3 a$} & 3 & $\mathrm{~B}(\mathrm{~B} 1)$ & Carbapenens & Não & Sim & $\begin{array}{c}\text { Hidrólise de amplo espectro, incluindo carbapenes mas não } \\
\text { monobactams }\end{array}$ & IMP-1, VIM-1, CcrA, IND-1 \\
\hline & & B (B3) & Carbapenens & & & & LI, CAU-1, GOB-1, FEZ-1 \\
\hline $3 b$ & 3 & $\mathrm{~B}(\mathrm{~B} 2)$ & Carbapenens & Não & Sim & Hidrolisam preferencialmente carbapenens & CphA, Sfh-1 \\
\hline $\mathrm{NI}$ & 4 & DE & & & & & \\
\hline
\end{tabular}

Nota: CA, ácido clavulânico; TZB, tazobactam; NI, não incluída; DE, desconhecido

Fonte: Adaptado de Bush, 2010 


\section{Oxacilinases}

Oxacilinases são carbapenemases do grupo $2 f$ da classificação de Bush, essas enzimas presentes em algumas cepas de Acinetobacter spp inativam preferencialmente os carbapenêmicos e algumas cefalosporinas, como cefepima, porém não atuam na ceftazidima (Jeon et al., 2005; Pournaras et al., 2006). E não parecem ser induzidas pela presença de antibióticos, como o imipenem (WaltherRasmussen, 2006).

A resistência aos carbapenêmicos em $A$. baumannii ocorre principalmente devido à expressão de várias OXA- $\beta$-lactamases, como OXA-23, OXA-58, OXA40 e OXA-143, bem como por super expressão intrínseca da OXA-51-like (Pfeifer et al, 2011).

No ano de 2009, foi relatada na França uma nova classe de oxacilinase, cujo o único membro descrito até o momento é a Oxa-143. Essa nova classe possui uma similaridade de $88 \%$ com a seqüência de aminoácidos da Oxa- 40 , $63 \%$ de similaridade com a Oxa-23 e 52\% de similaridade com a Oxa-58. (Higgins et al; 2009)

Alguns autores demonstraram a associação da presença de oxacilinase tipo 51 à espécie Acinetobacter baumannii, e juntamente com as integrases de classe 1, esta oxacilinase parecem ser um poderoso marcador para a detecção dessa espécie (Turton et al., 2006; Feizabadi et al., 2008).

Em uma cepa Acinetobacter baumanni isolada no Brasil em 2004, resistente aos carpabenêmicos, mas com nenhum gene codificador de carbapenemase detectado por PCR, foi descrita a presença de gene codificador de OXA-143 por Higgins e colaboradores em 2009. Esse gene OXA-143 é o primeiro representante de uma subclasse $D$ que hidrolisa carbapenêmicos, $\beta$ lactamases, e está relacionada com a OXA-40. As $\beta$-lactamases OXA-143 hidrolisam penicilinas e carbapenêmicos, mas não hidrolisam significativamente cefalosporinas de amplo espectro, como é observado com outras CHDLs. 
Posteriormente essa enzima foi descrita em outros estudos brasileiros (Mostachio et al 2012).

\section{Metalo- $\beta$-lactamases}

As metalos- $\beta$-lactamases (M $\beta$ Ls) estão agrupadas na classe $B$ de Ambler e na classe 3 de Bush (Bush et al., 1995), possuem quatro características principais: (i) atividade contra os carbapenêmicos; (ii) não hidrolisam os monobactans, como aztreonam; (iii) são inibidas por agentes quelantes, como EDTA, derivados do tiol e ácido dipicolínico; (iv) requerem íons $\mathrm{Zn}^{+2}$ ou outros cátions divalentes como co-fatores (Laraki et al., 1999).

Vários estudos caracterizaram os genes de $\mathrm{M} \beta \mathrm{L}$ dentro de integrons, tanto de classe 1 como da classe 3. Esses integrons, quando localizados em transposons ou plasmídios, são responsáveis por disseminar esses genes para várias espécies de bactérias (Shibata et al., 2003; Jeong et al., 2003).

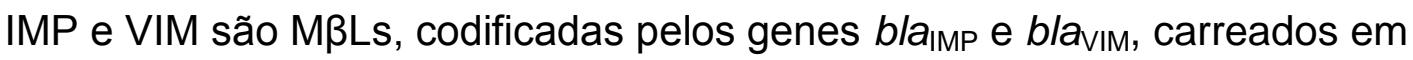
"cassetes" gênicos móveis inseridos nos integrons de classe 1 (Arakawa et al., 2000). Em 1991, no Japão, foi reportada uma nova M $\beta$ L, IMP-1, mediada por plasmídeos identificados em isolados de $P$. aeruginosa (Walsh et al, 2002). Uma nova família de $\mathrm{M} \beta \mathrm{L}$, a família VIM, foi descrita em isolados de $P$. aeruginosa na Itália, em 1997 (Lauretti, L. et al., 1999). A familía IMP é muito comum no sul da Ásia e a VIM no sul da Europa, Taiwan, Coréia e Japão (Lee et al, 2002). Já foram detectadas a presença dos genes bla $\left.\right|_{\mathrm{IMP}-1}$ e bla $\mathrm{IMP}_{\mathrm{M}-16}$ no Brasil (Sader et al, 2005).

Em um estudo realizado por Gales e colaboradores (2003), foi evidenciado o aparecimento e a disseminação de um clone de $P$. aeruginosa resistente aos carbapenêmicos em vários hospitais brasileiros. Nesse estudo foi identificada a presença de uma nova M $\beta L$ designada SPM (São Paulo Metalo- $\beta$-lactamase). Este foi o primeiro relato de disseminação de uma espécie produtora de $\mathrm{M} \beta \mathrm{L}$ com gene bla ${ }_{\mathrm{SPM} 1}$ em isolados de $P$. aeruginosa no Brasil. 
Várias $\mathrm{M} \beta \mathrm{L}$ s já foram descritas em Acinetobacter spp., dentre elas as mais encontradas são IMP-1 e VIM. Em 2005, uma nova classe de MßL foi descrita em Acinetobacter baumanni. Essa enzima, SIM-1, possui menor capacidade de hidrólise frente aos carbapênemicos quando comparada a outras classes de M $\mathrm{LL}$, como IMP e VIM (Qi, 2008).

Isolados de Acinetobacter spp. produtores de $\mathrm{M} \beta \mathrm{L}$ já foram descritos em surtos em hospitais brasileiros e em estudos utilizando banco de cepas (Gales et al, 2003; Tognim et al, 2006).

Dados do Hospital das Clinicas da FMUSP e de outros três hospitais de São Paulo identificaram a presença do gene bla-IMIP em $6 \%$ de 64 isolados de $A$. baumannii resistentes aos carbapênemicos (Mostachio et al, 2009).

A família GIM (German imipenemase) foi isolada em cepas de Acinetobacter spp. no ano de 2002 na Alemanha e a família SIM (Seoul imipenemase) na Korea. Desde a descoberta dessas MßLs: SPM, GIM e SIM, não foi constatada uma disseminação significativa a partir de seus países de origem (Queenan e Bush; 2007).

Recentemente a classe B carbapenemases NDM-1 (New Delhi metalo- $\beta$ lactamase) foi identificada inicialmente em Enterobactérias, na Índia, Paquistão, Bangladesh e no Reino Unido (Figura 1), mas também em muitos países do mundo. (Berçot et al, 2011). Apesar de descoberta em 2008, vários relatos já mostram a disseminação dessa resistência em todo o mundo, inclusive nos Estados Unidos e Austrália, associados na maioria dos casos com o subcontinente indiano. A NDM foi identificada principalmente em Escherichia coli e Klebsiella pneumoniae e em menor frequência em outras espécies de enterobácterias e também em Acinetobacter spp e $P$. aeruginosa. (Nordmann, et

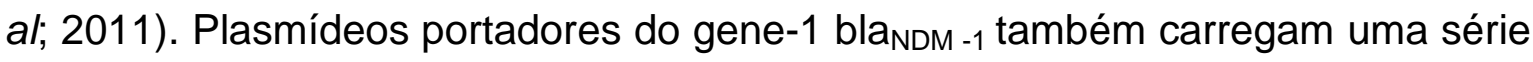
de outros genes que conferem resistência a todos os aminoglicosídeos, macrolídeos e sulfametoxazol, tornando esses isolados multirresistentes em alguns casos, a todos os antibióticos, incluindo a tigeciclina e a colistina (Kumarasamy, et al; 2010). 


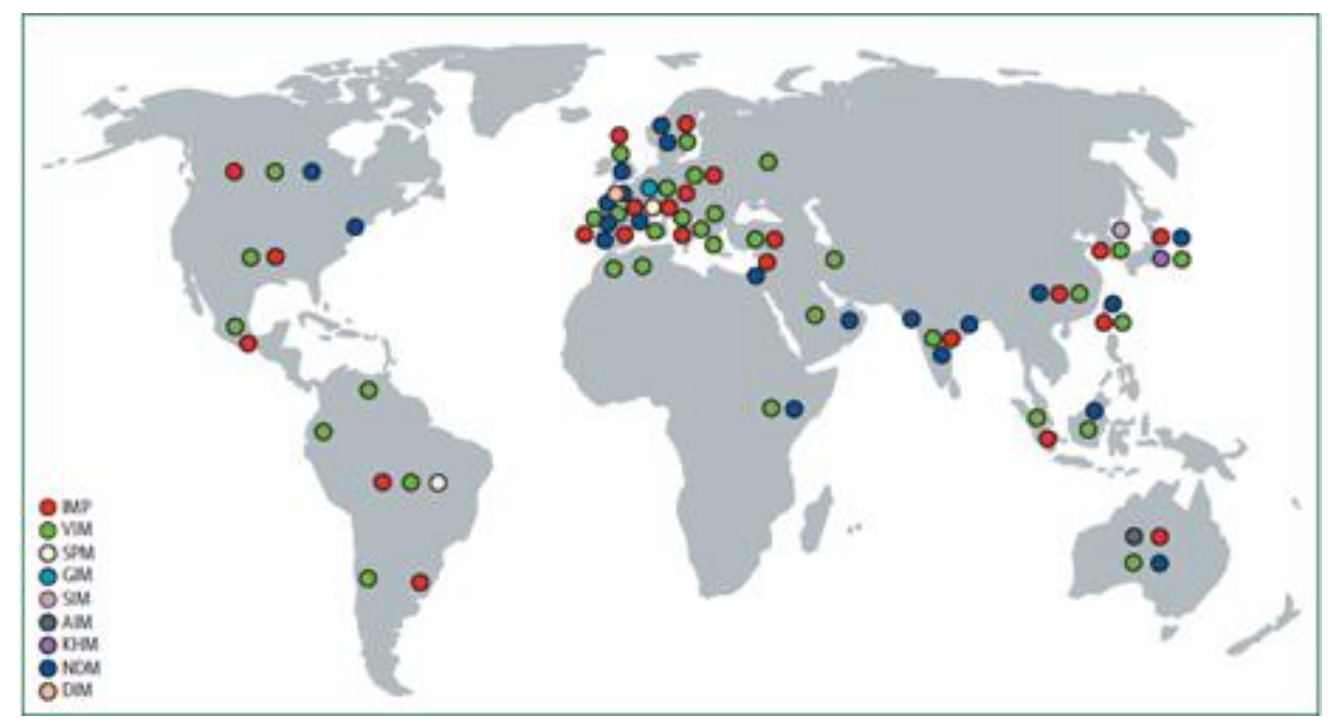

Figura 1- Disseminação no mundo dos diferentes tipos de M $\beta L s$.

Fonte: Cornaglia, et al; Review-2011

Um estudo observacional retrospectivo foi desenhado para avaliar a freqüência de $\mathrm{M} \beta \mathrm{L}$ entre os isolados de $P$. aeruginosa e Acinetobacter spp., obtidos em um hospital terciário no sul do Brasil. Os autores observaram que em um total de 223 isolados, a produção de $\mathrm{M} \beta \mathrm{L}$ foi detectada em 77,6\% dos isolados $P$. aeruginosa e $22,4 \%$ em isolados de Acinetobacter sp. Os isolados de Acinetobacter spp. apresentaram $92,8 \%$ de sensibilidade a amicacina e os isolados de $P$. aeruginosa apresentaram 58,9\% de sensibilidade ao aztreonam. Esses achados mostram a preocupação global com esse mecanismo de resistência (Machado et al; 2011).

Uma descoberta recente feita por Vella e colaboradores (2011), utilizou compostos de chumbo para o desenvolvimento de novos inibidores usando um ensaio colorimétrico baseado na cefalosporina cromogênica CENTA, e uma biblioteca de triagem de fragmentos do composto 500 Maybridge $^{\mathrm{TM}}$. As interações entre os fragmentos inibitórios e o ativo sítio da MßL da $K$. pneumoniae e $P$. aeruginosa foram testadas por meio de estudos por encaixe de silico. Os autores evidenciaram um número de compostos com constantes inibições sub-millimolar através da biblioteca de fragmento Maybridge ${ }^{\mathrm{TM}}$ que foram identificados como 
inibidores da $M \beta L$ IMP-1, caracterizando uma plataforma para o desenvolvimento adicional de compostos potentes comtra IMP-1 em particular, e em geral as MßLs.

Hussein e colaboradores (2012) estudaram os efeitos inibitórios sobre a atividade catalítica da IMP-1 das $P$. aeruginosa e K. pneumoniae produtoras de $\mathrm{M} \beta \mathrm{L}$ em dois conjuntos sintetizados de tetrahidropirimidina-2-tiona e de derivados pirrole, mostrando que esses novos inibidores podem ser promissores para inibição das MßL.

\section{Outras $\beta$-lactamases}

A resistência aos carbapenêmicos também pode ser causada pelas carbapenemases da classe A ou em raras ocasiões pelas carbapenemases da classe $D$ ou carbapenemases do tipo OXA. Estão incluídas no grupo das carbapenemases da classe A (Ambler, 1980) ou grupo $2 f$ de Bush as enzimas do tipo GES (9 variantes), KPC (4 variantes), SME (3 variantes), IMI, NMC-A, SFC-1 (Walther, et al; 2007).

O primeiro membro da família KPC foi descoberto durante o projeto de vigilância "ICARE" em um isolado clínico de Klebsiella pneumoniae na Carolina do Norte em 1996. (Yigit et al., 2001). Villegas e colaboradores (2007) relataram o primeiro caso da enzima KPC fora da família Enterobactérias ocorrido em $P$. aeruginosa, em Medellin, Colômbia.

Desde o primeiro relato em 2001, a resistência ao carbapenêmicos mediada pela produção de KPC é cada vez mais identificada nos Estados Unidos e mais recentemente em todo o mundo. Inicialmente confinada principalmente a K. pneumoniae, estas enzimas são agora relatadas em várias espécies de Enterobácterias, e também em Gram-negativos não fermentadores como $P$. aeruginosa e A. baumannii (Villegas, et al., 2007; Robledo et al., 2009). 
O primeiro caso de KPC em isolados $P$. aeruginosa foi descrito em 2007 na Colombia (KPC-2). No Brasil o primeiro relato foi descrito por Jácome e colaboradores (2012), que isolaram duas cepas resistentes aos carbapenêmicos em fevereiro de 2010 de dois pacientes internados na UTI de um Hospital localizado em Recife.

A $\beta$-lactamase de espectro extendido GES- 1 foi identificada inicialmente em um isolado de Klebsiella pneumoniae em 1998, desde então duas enzimas estreitamente correlacionadas, IBC-1 ("integron-borne cephalosporinase") e GES2, vem sendo descritas (Castanheira, et al., 2004).

Embora raras, as enzimas GES têm sido descrita em todo mundo, principalmente na Grécia, França, Portugal, África do Sul, Guiana Francesa, Brasil, Argentina, Korea e Japão, elas estão sendo cada vez mais freqüente (Pellegrino et al, 2006; Da Fonseca et al, 2007; Picão et al, 2009 ).

Como mencionado acima a GES-1 foi inicialmente caracterizada em isolados de K. pneumoniae na França, mas têm sido descrita em outras bactérias. GES-2 foi descrita na África do Sul em um isolado clínico de $P$. aeruginosa, GES5, GES-6, GES-7 e GES-8 na Grécia, e GES-3 e GES-4 no Japão. A carbapenemase GES-5 tem sido reportada também na Corea, China e no Brasil. Essa enzima tem sido descrita também A. baumannii desde GES-11, GES-12 e GES-14 que foram descrita na Bélgica (Poirel et al, 2012).

\section{Métodos fenotípicos de triagem de carbapenemases}

$\mathrm{Na}$ última década foram descritos alguns métodos de triagem de $\mathrm{M} \beta \mathrm{L}$ em isolados de $P$. aeruginosa e $A$. baumannii resistentes aos carbapenêmicos (Arakawa et al., 2000; Migliavacca et al., 2002; Walsh et al., 2002). Alguns estudos mostraram que as MßLs são inibidas por EDTA e outros íons de metal quelantes. Em 2000, Arakawa e colaboradores testaram EDTA e vários íons quelantes inibidores das M $\beta L$ s e estabeleceram um método de difusão com duplo 
disco para triagem de $\mathrm{M} \beta \mathrm{L}$. Dentre os íons quelantes o que demonstrou melhor resultado foi o ácido 2-mercapto propiônico, pelo fato de bloquear a atividade da $M \beta L$ mais efetivamente. $O$ antimicrobiano ceftazidima (CAZ) pareceu ser um bom substrato para este teste, considerando-se que amostras produtoras de $M \beta L$ (IMP-1) usualmente demonstram alto nível de resistência a ceftazidima (CIM > $64 \mathrm{mg} / \mathrm{ml}$ ), fato confirmado em estudos anteriores em que um considerável efeito inibitório dos compostos tiólicos foi observado (Senda et al., 1996).

Walsh e colaboradores (2002) também avaliaram a produção de $\mathrm{M} \beta \mathrm{L}$ por meio de uma fita de Etest ${ }^{\circledR}$, que contém em uma extremidade imipenem e na outra imipenem mais EDTA. Como no procedimento utilizado para interpretação nas fitas para determinação de ESBL, uma redução maior ou igual a 3 diluições, i.e, razão entre CIMs obtidos metalo- $\beta$-lactamase pela cepa testada, assim como a formação de zonas fantasmas entre os dois gradientes formados, obtendo $100 \%$ de sensibilidade e especificidade quando comparados com métodos bioquímicos e genotípicos para $P$. aeruginosa e Acinetobacter spp.. Um estudo realizado no Hospital das Clínicas de São Paulo, durante o ano 2006, determinou a freqüência de $\mathrm{M} \beta \mathrm{L}$ em 69 isolados de corrente sanguínea de $P$. aeruginosa resistente a imipenem, e comparou métodos fenotípicos e PCR. A positividade dos testes fenotípicos para M $\mathrm{ML}$ variou entre $28 \%$ - 77\% e a PCR foi positiva em $30 \%$, sendo $81 \%$ para gene bla SPM-1 e 19\% para bla VIM-2 (Franco et al., 2010).

A detecção laboratorial de $P$. aeruginosa produtoras de $M \beta L$ não está bem definida em regiões com baixa prevalência destas enzimas. Van Der Bij e colaboradores (2011) desenvolveram um teste de triagem usando discos com EDTA, doripenem, imipenem e meropenem. Os autores avaliaram 96 isolados de P. aeruginosa e compararam o teste com EDTA com a fita Etest ${ }^{\circledR}$ para MBL. O teste de triagem com imipenem mais EDTA, mostrou sensibilidade de $100 \%$ e especificidade de $90 \%$. O imipenem em combinação com doripenem mostrou um melhor desempenho que o imipenem sozinho, obtendo sensibilidade de $100 \% \mathrm{em}$ ambos os testes e especificidade respectivamente de $90 \%$ e $95 \%$. A fita de Etest para $\mathrm{M} \beta \mathrm{L}$ teve sensibilidade de $100 \%$ e especificidade de $95 \%$. 
Vella et al., 2011, descreveram o uso de compostos de chumbo para o desenvolvimento de novos inibidores de $\mathrm{M} \beta \mathrm{L}$ usando ensaio colorimétrico baseado na cefalosporina cromogênica (CENTA), e um composto R03 da biblioteca de fragmento 500 Maybridge $^{\mathrm{TM}}$. Esse composto foi identificado como inibidor da MBL- IMP-1 e o uso da CENTA como um substrato adequado e o nitrocefin como alternativa de triagem de inibidor.

Clinicamente as infecções por Enterobacterias spp. produtoras de KPC têm sido associadas ao aumento da mortalidade dos pacientes. Do ponto de vista de controle de infecção, K. pneumoniae e Escherichia coli produtoras de KPC tem causado surtos em hospitais (Monteiro et al., 2009). A enzima KPC além de ser encontrada nas enterobactéricas de todo mundo, recentemente foi descrita em isolados $P$. aeruginosa na Colombia, Porto Rico, Trindade, Tobago e Brasil e Estados Unidos e nos A. baumannii em Porto Rico (Robledo, et al., 2011).

O teste de Hodge modificado ( $\mathrm{MHT}$ ) tem sido extensivamente utilizado como uma técnica para a detecção fenotípica das carbapenemases, uma vez que está disponível na rotina de microbiologia e sugerido pelo CLSI (Girlich, et al.,2012). Entretanto, ele é muito sensível e pouco específico, e a presença de carbapenemase deve ser confirmada por meio de PCR.

Amjad e colaboradores (2011) avaliaram o teste de Hodge modificado como é descrito hoje é uma versão modificada do teste de Hodge que foi utilizado há alguns anos para triagem de M $\beta L$ IMP-1 e VIM-2. O teste de Hodge original utilizava disco de imipenem 10ug que deu resultados bons, uma vez que foram detectados 67\% de casos de produção M $\mathrm{ML}$ em Pseudomonas aeruginosa e Acinetobacter spp. Os outros 13 casos que deram resultados inicialmente duvidosos ou negativos foram testados e foram declarados positivos utilizando discos de imipenem contendo sulfato de zinco.

Compostos de ácido borônico são conhecidos como excelentes inibidores da classe $C \beta$-lactamases. $O$ ácido 3-borônico aminofenil (APB) foi utilizado na detecção da produção mediada por plasmídeo da classe $C$-lactamases em Enterobácterias. Esse estudo investigou os efeitos da APB em isolados positivos 
para produção da carbapenemase KPC e de outras não produtoras dessa enzima (Doi, Y. et al., 2008).

Um estudo de detecção fenotípica foi realizado em 90 amostras de $P$. aeruginosa resistentes aos carbapenêmicos num Centro Médico Universitário na Malásia, 32 isolados eram positivas para M $\beta L$ por PCR, foram submetidas a teste de duplo disco por sinergismo (DDST), teste de disco combinado (CDT) e Etest ${ }^{\circledR}$ para MBL. Os três testes apresentaram 100\% de sensibilidade. No entanto, DDST foi o mais específico dos três $(96,6 \%)$, seguido por Etest ${ }^{\circledR}$ para $M \beta L(62,1 \%)$ e o CDT com $(43,1 \%)$. Com base no critério de dupla interpretação, eles concluíram que o Etest ${ }^{\circledR}$ para MBL é um ensaio viável com $100 \%$ de sensibilidade e boa especificidade para triagem de $M \beta L$ na rotina deles, já que a detecção pela PCR não é uma opção viável. E assim, recomendaram que os ensaios fenotípicos devam ser avaliados e adaptados com a base da situação local. (Khosravi, 2012). 


\section{Justificativa do estudo}

Apesar dos inúmeros estudos publicados na literatura que comparam a detecção fenotípica da produção de carbapenemase com a genotípica em isolados de $P$. aeruginosa e Acinetobacter spp., não existe um consenso, entretanto, de qual seria o melhor método fenotípico para triagem desse mecanismo de resistência.

Um método fenotípico de fácil realização e interpretação pode ser útil na identificação precoce de surtos e no controle da disseminação da resistência decorrente da produção de carbapenemase, já que muitos desses genes podem ser transmitidos por elementos genéticos móveis como integrons e seqüências de inserção. 


\section{OBJETIVOS}

\section{Principal}

Comparar os métodos fenotípicos de triagem de carbapenemases com os métodos genotípicos, em isolados de $P$. aeruginosa e $A$. baumannii resistentes aos carbapenêmicos.

\section{Secundários}

$\checkmark$ Correlacionar os resultados dos diferentes métodos de triagem de carbapenemases com as CIMs dos carbapenêmicos dos isolados.

$\checkmark$ Avaliar a linhagem clonal dos isolados. 


\section{MATERIAIS E MÉTODOS}

\subsection{Amostras bacterianas}

Foram analisadas 158 amostras de Acinetobacter spp e Pseudomonas aeruginosa resistentes aos antimicrobianos carbapenêmicos, obtidas do banco de cepa do LIM 54 (Laboratório de Investigação Médica) de isolados de hemoculturas de pacientes atendidos no Hospital das Clínicas.

Dos Acinetobacter spp., foram escolhidas aleatoriamente 50 isolados, no período de 2002 a 2004, foram reidentificadas pelo método manual de API20 NE (bioMériux, França), com leitura de 24 e 48 horas.

Pseudomonas aeruginosa, foram escolhidas 108 isolados, no período de 1998 a 2009 resistentes ao imipenem e meropenem, que foram identificados manualmente e por sistema automatizado Vitek ${ }^{\circledR}$ (bioMérieux, EUA) com cartão GNI.

\subsection{Protocolo para determinação dos halos de inibição (método de difusão de disco ou método de Kirby-Bauer)}

Preparação e padronização do inóculo: foi preparada uma suspensão bacteriana, a partir de uma placa com crescimento bacteriano de 18 a 24 horas, na escala 0,5 McFarland.

A suspensão bacteriana foi preparada medindo-se a densidade óptica em espectrofotômetro, num comprimento de onda de $625 \mathrm{~nm}$, onde a escala 0,5 de McFarland correspondeu a uma D.O de 0,08 a 0,1. Quando a turvação do inóculo do teste estiver similar à turvação padrão da escala padrão, significa que contém aproximadamente $1,5 \times 10^{8} \mathrm{UFC} / \mathrm{mL}$. 
Inoculação da placa de meio de cultura: para o teste de difusão de disco foi utilizado o ágar MH (Müeller Hinton), pH 7,2 a 7, 4, com espessura de 3 a 3 mm, conforme normas padronizadas pelo CLSI (M7-A5, 2002).

Procedimento: mergulhou um "swab" de algodão estéril no tubo do inóculo, levantou acima do líquido e girou de encontro à parede do tubo para remoção do líquido excedente. Aplicou o inóculo na placa, cobrindo a superfície inteira, girando 60 graus e aplicou na superfície inteira, girando 60 graus e aplicou novamente.

\subsection{Microdiluição em caldo}

As cepas resistentes ao imipenem tiveram suas CIMs (concentração inibitória mínima) determinadas pelo método de microdiluição em caldo MHCA (Müeller-Hinton Cátion Ajustado), conforme normas padronizadas pelo CLSI (M7A5, 2005).

Controle de Qualidade: De acordo com os critérios do CLSI, foram utilizados como cepas controle P. aeruginosa ATCC 27853 e E.coli ATCC 25922.

Para determinação da CIM pelo método da microdiluição em caldo os seguintes passos foram seguidos:

Preparo da solução estoque do antimicrobiano: $O$ antimicrobiano testado continha em seu rótulo as seguintes informações: número do lote, prazo de validade e a potência expressa em Ul/mg ou $\mu \mathrm{g} / \mathrm{mg}$. Para calcular a quantidade necessária do antimicrobiano, foi utilizada a seguinte fórmula:

\section{Peso $(\mathrm{mg})=\underline{\text { Volume }(\mathrm{mL}) \times \text { Concentração }(\mu \mathrm{g} / \mathrm{mL})}$ \\ Potência $(\mu \mathrm{g} / \mathrm{mg})$}

Foi utilizado o solvente apropriado para cada antimicrobiano (CLSI, M100-S12, 2005). A concentração final da solução estoque foi de $10.000 \mu \mathrm{g} / \mathrm{mL}$. 
Número de diluições: As concentrações que foram testadas seguiram os cortes descritos nas Tabelas do documento M100-S12 (para uso com M7-A5, CIM) do CLSI, normalmente de $256 \mu \mathrm{g} / \mathrm{mL}$ a $0,125 \mu \mathrm{g} / \mathrm{mL}$. Para obter a solução de 256 $\mu \mathrm{g} / \mathrm{mL}$, a solução estoque com concentração igual a $10.000 \mu \mathrm{g} / \mathrm{mL}$. A partir da solução estoque, foram realizadas diluições do antimicrobiano com o diluente adequado (CLSI, M100-S12, 2005), até obter uma diluição de $256 \mu \mathrm{g} / \mathrm{mL}$.

Preparo das diluições na placa: $50 \mu \mathrm{L}$ de meio de cultura CMHCA (Caldo Müeller-Hinton Cátion Ajustado) foi colocado em todos os pocinhos da placa, exceto na coluna 1. $100 \mu \mathrm{L}$ da diluição a $256 \mu \mathrm{g} / \mathrm{mL}$ foi colocado em todos os pocinhos da coluna 1. Com uma pipeta multicanal, foi realizada diluição seriada do antimicrobiano pipetando $50 \mu \mathrm{L}$ do primeiro pocinho da linha $A(A 1)$ para o segundo pocinho da linha $A(A 2)$. Homogenizou bem com a pipeta e em seguida pipetou $50 \mu \mathrm{L}$ do pocinho $\mathrm{A} 2$ para o $\mathrm{A} 3$. Este procedimento foi realizado até $\mathrm{o}$ pocinho $A 11$, deixando o pocinho $A 11 \mathrm{com}$ volume final de $100 \mu \mathrm{L}$, o qual foi designado como controle de esterilidade (não se deve acrescentar células bacterianas neste poço, pois permite verificar a ocorrência de contaminação durante a diluição do antimicrobiano). O último pocinho de cada linha (A12 - H12) foi utilizado como controle de crescimento bacteriano, ou seja, $50 \mu \mathrm{L}$ de meio de cultura MCHA + $50 \mu \mathrm{L}$ de suspensão bacteriana (diluída 1:100).

Preparo da suspensão bacteriana: Foi preparado uma suspensão bacteriana na escala 0,5 de McFarland ( $\left.1,8 \times 10^{8} \mathrm{UFC} / \mathrm{mL}\right)$ por espectrofotometria e diluída esta suspensão 1:100 em solução fisiológica ou MHCA (1,8 x 106 UFC/mL).

Inoculação da suspensão bacteriana: adicionado $50 \mu \mathrm{L}$ desta solução diluída nos poços 1 a 10 e no poço 12 de todas as colunas $(\mathrm{A}$ a $\mathrm{H})$. Após o preparo das diluições, foi realizada inoculação nos poços dentro de 30 minutos. A concentração final da suspensão foi de aproximadamente $5 \times 10^{5} \mathrm{UFC} / \mathrm{mL}$. Após semeadura, as placas foram homogeneizadas sobre a bancada em movimento rotatório. Foi colocado sob as placas um papel de filtro estéril umedecido com água destilada estéril ou um saco plástico estéril e incubado as placas a $35^{\circ} \mathrm{C}$ por 16 a 20 horas, atmosfera ambiente (CLSI, M100-S12, 2005). 
Leitura dos CIMs: a leitura das placas foi realizada em local iluminado ou com auxílio de uma luminária ou de um espelho para leitura das placas. O CIM foi determinado de acordo com a observação de crescimento bacteriano nos pocinhos e através de um leitor de ELISA, utilizando um comprimento de onda de $450 \mathrm{~nm}$ (o controle de esterilidade será o BRANCO do teste.)

\subsection{Detecção de Metalo- $\beta$-lactamase pelo método do Etest ${ }^{\circledR}$ (AB Biodisk (North América Inc., N.J.)}

Preparação e padronização do inóculo: uma suspensão bacteriana foi preparada a partir de uma placa com crescimento bacteriano de 18 a 24 horas, na escala 0,5 de McFarland e comparado com uma escala de turvação padrão. A suspensão bacteriana também pode ser quantificada pela densidade óptica em espectrofotômetro, num comprimento de onda de $625 \mathrm{~nm}$, onde a escala 0,5 de McFarland corresponde à densidade óptica de 0,08 a 0,1 ( 1,5 x 10 $\left.{ }^{8} \mathrm{UFC} / \mathrm{mL}\right)$.

Inoculação da placa de meio de cultura: para $\circ$ Etest $^{\circledR}$ foi utilizado o ágar Müeller-Hinton, conforme documento do CLSI (M7-A5, 2002). O procedimento foi igual aquele realizado no método de difusão do disco.

Aplicação das fitas de Etest: foram utilizadas fitas de Etest ${ }^{\circledR}$ para $M \beta L$, onde uma extremidade contém imipenem (IP) e na outra extremidade contém imipenem associado com EDTA (IPI).

Incubação do teste: as placas foram incubadas a $35^{\circ} \mathrm{C}$ por 16 a 18 horas, em posição invertida (lado do ágar para cima).

Leitura da CIM: após 16 a 18 horas, verificou se o crescimento sobre o ágar estava confluente e uniforme, com zonas de inibição elípticas.

O CIM a partir de observação através da utilização de luz direta e não refletida.

Interpretação dos resultados: a sensibilidade foi determinada de acordo com os critérios propostos por Walsh et al. (2002). 


\subsection{Detecção Metalo- $\beta$-lactamase pelo método de Arakawa et al. (2000) modificado (Teste do duplo disco sinergismo - DDST e Disco combinado - CD)}

Preparação e padronização do inóculo: foi preparada uma suspensão bacteriana, a partir de uma placa com crescimento bacteriano de 18 a 24 horas, na escala 0,5 de McFarland e comparado com uma escala de turvação padrão. A suspensão bacteriana também pode ser quantificada pela densidade óptica em espectrofotômetro, num comprimento de onda de $625 \mathrm{~nm}$, onde a escala 0,5 de McFarland corresponde à densidade óptica de 0,08 a 0,1 ( 1,5 x 10 $\left.{ }^{8} \mathrm{UFC} / \mathrm{mL}\right)$.

Inoculação da placa de meio de cultura: foi utilizado o ágar Müeller-Hinton, conforme documento do CLSI (M7-A5, 2002). O procedimento é igual aquele realizado no método de difusão do disco.

Aplicação dos discos de sensibilidade: três discos de ceftazidima (CAZ) $30 \mu \mathrm{g}$ foram colocados nas placas. A distância entre os discos foi de $4 \mathrm{~cm}$ e dois discos filtros foram colocados próximos de um dos discos de ceftazidima. Com uma distância de centro para centro de $2 \mathrm{~cm}$. Em um dos discos foram inoculados $3 \mu \mathrm{L}$ do ácido $\beta$-mercaptoetanol não diluído e no outro disco foi inoculado $5 \mu \mathrm{L}$ de EDTA 0,5M pH 8,0.

Em outra placa de Müeller-Hinton foram colocados três discos de imipenem de $10 \mu \mathrm{g}$ com distância de $4 \mathrm{~cm}$ entre si. Com uma distância de $2 \mathrm{~cm}$ de centros de dois dos discos de imipenem foram colocados dois discos filtros onde foi inoculado num dos discos $3 \mu \mathrm{L}$ do $\beta$-mercaptoetanol e no outro $5 \mu \mathrm{L}$ de EDTA $0,5 \mathrm{M} \mathrm{pH} 8,0$. Outro disco de imipenem foi colocado na placa com uma distância de $4 \mathrm{~cm}$ para um dos discos de imipenem e foi acrescentado $4 \mu \mathrm{L}$ de EDTA 0,5M $\mathrm{pH} 8,0$.

Incubação do teste: as placas foram incubadas a $35^{\circ} \mathrm{C}$ por 16 a 18 horas, em posição invertida (lado do ágar para cima).

Leitura de zona de inibição: após 16 a 18 horas foi verificado se o crescimento sobre o ágar foi confluente e uniforme, com zonas de inibição circulares. A 
medição do diâmetro da zona de inibição em milímetros foi feita usando luz direta e não refletida.

Interpretação dos resultados: os halos de inibição foram interpretados de acordo com os critérios propostos por Arakawa et al. (2000).

\subsection{Detecção de Carbapenemases pelo método de Hodge modificado (Lee et} al., 2001).

Preparação e padronização do inóculo: uma suspensão bacteriana da $E$. coli ATCC 25922 foi preparada a partir de uma placa com crescimento bacteriano de 18 a 24 horas, na escala 0,5 de McFarland e comparado com uma escala de turvação padrão e depois essa solução foi diluída na escala 1:10.

Inoculação da placa de meio de cultura: foi utilizado o ágar Müeller-Hinton, conforme documento do CLSI (M7-A5, 2002). O procedimento é igual aquele realizado no método de difusão do disco. Após uma breve secagem (3 a 10 minutos) um disco de imipenem de $10 \mu \mathrm{g}$ foi inserido no centro da placa. A partir desse disco, foi realizado uma linha até a periferia da placa com um inóculo grosseiro ( 3 a 5 colônias) de uma cultura de crescimento em ágar sangue com tempo de incubação de 18 a 24 horas do isolado a ser testado

Incubação do teste: as placas foram incubadas a $35^{\circ} \mathrm{C}$ por 16 a 20 horas, em posição invertida (lado do ágar para cima).

Leitura do teste: foi analisado o crescimento da cepa padrão E. coli ATCC 25922 na proximidade do isolado testado. A presença de um ganho de crescimento do isolado padrão próximo ao isolado testado indica positividade na produção de carbapenemase. A ausência desse ganho de crescimento indica uma negatividade do teste. 


\subsection{Avaliação do método com disco de ácido borônico para detecção de carbapenemases}

Foi preparado discos impregnados com ácido fenilborônico (AFB) e ácido 3-aminofenilborônico ( $A A B$ ) em diferentes concentrações. $O$ ácido $A F B$ foi dissolvido em dimetil sulfoxide até uma concentração $20 \mathrm{mg} / \mathrm{mL}$, contendo $400 \mu \mathrm{g}$

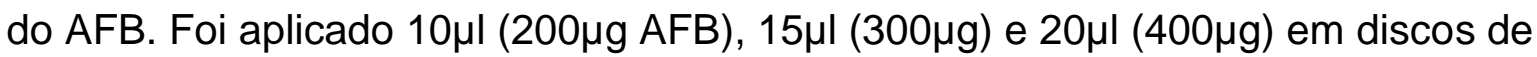
imipenem, meropenem e ertapenem.

O $A A B$ foi diluído em água destilada até uma concentração de $50.000 \mu \mathrm{g} / \mathrm{mL}$, contendo $300 \mu \mathrm{g}$ do AAB. Foi aplicado $4 \mu \mathrm{l}(200 \mu \mathrm{g} \mathrm{AAB}), 6 \mu \mathrm{l}$ $(300 \mu \mathrm{g})$ e $8 \mu \mathrm{l}(400 \mu \mathrm{g})$ em discos de imipenem, meropenem e ertapenem.

Foi aplicado os discos contendo os ácidos em diferentes concentrações em ágar Müeller- Hinton e colocado um disco de imipenem, meropenem ou ertapenem sem os ácidos, incubou as placas a $37^{\circ} \mathrm{C}$ overnight.

Foi feita a leitura comparando o aumento do diâmetro do disco com AFB ou $A A B$ com o disco sem o ácido. A interpretação dos halos de inibição foi realizada de acordo com os critérios descritos em trabalhos anteriores (Doi et al., 2008; Tsakris, et al., 2009).

\subsection{Análise sensibilidade e especificidade dos testes fenotípicos}

Foram calculadas sensibilidade (S), especificidade $(E)$, valores preditivos negativos (VPN) e valores preditivos positivos (VPP), dos testes fenotípicos usando como padrão-ouro a detecção de genes de codificadores de carbapenemases pelo método de PCR e por hidrólise. Os cálculos foram feitos segundo Mausner \& Bahn, 1974, seguindo as fórmulas abaixo:

Sensibilidade: $\mathrm{a} / \mathrm{a}+\mathrm{c}$

Especificidade: $d / b+d$

VPN: $d / c+d$

VPP: $a / a+b$ 


\subsection{Hidrólise}

Foi semeado as amostras em ágar sangue, após 0 isolamento colocou cerca de 10 colônias em tubo cônico contendo $10 \mathrm{ml}$ de caldo TSB (triptona de soja). Incubou os tubos em estufa a $37^{\circ} \mathrm{C}$ sob agitação durante 12 horas.

Foi centrifugado a suspensão bacteriana por 15 minutos a $3 \mathrm{rpm}$. Em seguida, desprezou o sobrenadante e ressuspendeu em $1 \mathrm{ml}$ de solução de hidrólise (Tris- $\mathrm{HCl} 1 \mathrm{mM} \mathrm{e} \mathrm{ZnSO}_{4} 1 \mathrm{mM}$ ). Ultrasonicou as amostras suspensas em 4 ciclos de 30 segundos. Transferiu o produto sonicado para um tubo de microcentrífuga e, então, centrifugou por 3 minutos a $4^{\circ} \mathrm{C}$ a $13000 \mathrm{rpm}$. $\mathrm{O}$ sobrenadante contento o extrato protéico bruto das células bacterianas foi transferido para um novo tubo e mantido em gelo até o momento da execução do ensaio.

Para verificar a atividade de hidrólise foi preparada uma solução de imipenem em tampão fosfato $0,1 \mathrm{M}, \mathrm{pH} \quad 7,0$ a uma absorbância de aproximadamente 1,5 a 2 unidades de absorbância a $299 \mathrm{~nm}$.

Em uma cubeta de quartzo foi adicionado $1800 \mu \mathrm{l}$ da solução de antimicrobiano, juntamente com $200 \mu \mathrm{l}$ do extrato bruto de $\beta$-lactamase. $\mathrm{O}$ monitoramento da absorbância da solução de antimicrobianos indica um resultado positivo para a produção de carbapenemase. A variação da absorbância foi calculada através da diferença entre o valor de absorbância final e inicial após um minuto de leitura $(\triangle \mathrm{Abs} / \mathrm{min})$. Foi utilizado como controle uma amostra de $P$. aeruginosa conhecida como SPM (UNIFESP) e A. baumannii OXA-23 (LIM-54).

As amostras que apresentaram resultado positivo para o teste de hidrólise foram submetidas ao teste de inibição da atividade pelo EDTA. Neste caso, $235 \mu \mathrm{l}$ do extrato protéico foi incubado à temperatura ambiente durante 20 minutos juntamente com $15 \mu \mathrm{l}$ de EDTA $500 \mathrm{mM} \mathrm{pH} \mathrm{8,0.} \mathrm{Como} \mathrm{controle} \mathrm{positivo} \mathrm{para} \mathrm{a}$ reação de inibição, $235 \mu \mathrm{l}$ do extrato protéico de cada amostra foi incubado com $15 \mu \mathrm{l}$ de solução de hidrólise à temperatura ambiente por 20 minutos. $O$ teste em que se observou a ausência de variação da absorbância do extrato incubado com 
EDTA foi considerado positivo para inibição, sugestivo da produção de carbapenemases do tipo $\mathrm{M} \beta \mathrm{L}$ pelas amostras bacterianas testadas.

\subsection{Detecção de genes codificadores para $\beta$ - lactamase}

\subsubsection{Extração de DNA}

A extração de DNA foi realizada pelo GenomicPrep ${ }^{T M}$ and Tissue DNA Isolation Kit - Amersham Pharmacia Biotech, através do procedimento $E$ (extração de DNA de bactérias Gram-negativas).

\subsubsection{Reação de amplificação em cadeia da polimerase (PCR) para detecção} de genes de resistência

A reação de multiplex PCR para os genes codificadores de IMP, VIM, SPM, GIM e SIM foi realizada de acordo com os critérios propostos por Ellington et al. (2006).

As detecções dos demais genes de resistência foram realizadas de acordo com os critérios propostos pelas referências citadas na Tabela 1. 
Tabela 1 - Sequência de primers utilizados para as reações de PCR

\begin{tabular}{|c|c|c|c|c|}
\hline $\begin{array}{l}\text { Mecanismo de } \\
\text { resistência }\end{array}$ & Gene & $\begin{array}{l}\text { Seqüência de oligonucleotídeos } \\
\left.\text { iniciadores (5'- } 3^{\prime}\right)\end{array}$ & $\begin{array}{l}\text { Tamanho } \\
\text { do } \\
\text { Amplicon } \\
\text { (pb) }\end{array}$ & Referência \\
\hline \multirow{2}{*}{$\begin{array}{c}\text { Carbapenemase } \\
M \beta L\end{array}$} & & GAATAGAATGGCTTAACTCTC & & \multirow{2}{*}{$\begin{array}{l}\text { Mendes et al., } \\
2007\end{array}$} \\
\hline & $b / a_{\mathrm{IMP}}$ & CCAAACCACTAGGTTATC & 188 & \\
\hline \multirow{2}{*}{$\begin{array}{c}\text { Carbapenemase } \\
\mathrm{M} \beta \mathrm{L}\end{array}$} & & GTTTGGTCGCATATCGCAAC & & \multirow{2}{*}{$\begin{array}{l}\text { Mendes et al., } \\
2007\end{array}$} \\
\hline & $b^{b} a_{\mathrm{VIM}}$ & AATGCGCAGCACCAGGATAG & 382 & \\
\hline \multirow{2}{*}{$\begin{array}{c}\text { Carbapenemase } \\
\mathrm{M} \beta \mathrm{L}\end{array}$} & & TCGACACACCTTGGTCTGAA & & \multirow{2}{*}{$\begin{array}{l}\text { Mendes et al., } \\
2007\end{array}$} \\
\hline & $b / a_{\mathrm{GIM}-1}$ & ААСTTCCAАСTTTGCCATGC & 477 & \\
\hline \multirow{2}{*}{$\begin{array}{c}\text { Carbapenemase } \\
\mathrm{M} \beta \mathrm{L}\end{array}$} & & GTACAAGGGATTCGGCATCG & & \multirow{2}{*}{$\begin{array}{l}\text { Mendes et al., } \\
2007\end{array}$} \\
\hline & bla $a_{S I M-1}$ & TGGCCTGTTCCCATGTGTGAG & 569 & \\
\hline \multirow{2}{*}{$\begin{array}{c}\text { Carbapenemase } \\
M \beta L\end{array}$} & & CTA AATCGAGAGCCCTGCTTG & & \multirow{2}{*}{$\begin{array}{l}\text { Mendes et al., } \\
2007\end{array}$} \\
\hline & blasPM & СCT TTTCCGCGACCTTGATC & 798 & \\
\hline \multirow{2}{*}{$\begin{array}{c}\text { Carbapenemase } \\
\mathrm{M} \beta \mathrm{L}\end{array}$} & & GGCGGAATGGCTCATCACGA & & \multirow{2}{*}{$\begin{array}{l}\text { Chen et al., } \\
2011\end{array}$} \\
\hline & $B / a_{\mathrm{NDM}}$ & CGCAACACAGCCTGACTTTC & 287 & \\
\hline \multirow{2}{*}{$\begin{array}{l}\text { Carbapenemase } \\
\text { Classe A }\end{array}$} & & ATGCGCTTCATTCACGCAC & & \multirow[b]{2}{*}{ Kim et al., 2007} \\
\hline & bla $a_{\mathrm{GES}}$ & CTATTTGTCCGTGCTCAGG & 846 & \\
\hline \multirow{2}{*}{$\begin{array}{l}\text { Carbapenemase } \\
\text { Classe A }\end{array}$} & & ATGTCACTGTATCGCCGTCT & & \multirow{2}{*}{$\begin{array}{c}\text { Bradford et al., } \\
2004\end{array}$} \\
\hline & $b_{1} a_{K P C}$ & TTTTCAGAGCCTTACYGCCC & 893 & \\
\hline \multirow{2}{*}{$\begin{array}{l}\text { Carbapenemase } \\
\text { Oxacilinase }\end{array}$} & & TAATGCTTTGATCGGCCTTG & & \multirow{2}{*}{$\begin{array}{l}\text { Woodford et al., } \\
2006\end{array}$} \\
\hline & bla Oxa-51 & TGGATTGCACTTCATCTTGG & 353 & \\
\hline \multirow{2}{*}{$\begin{array}{c}\text { Carbapenemase } \\
\text { Oxacilinase }\end{array}$} & & GATCGGATTGGAGAACCAGA & & \multirow{2}{*}{$\begin{array}{c}\text { Woodford et al., } \\
2006\end{array}$} \\
\hline & bla $\mathrm{Oxa-23}$ & ATTTCTGACCGCATTTCCAT & 501 & \\
\hline \multirow{2}{*}{$\begin{array}{c}\text { Carbapenemase } \\
\text { Oxacilinase }\end{array}$} & & GGTTAGTTGGCCCCCTTAAA & & \multirow{2}{*}{$\begin{array}{l}\text { Woodford et al., } \\
2006\end{array}$} \\
\hline & bla ${ }_{\mathrm{Oxa}-24}$ & AGTTGAGCGAAAAGGGGATT & 246 & \\
\hline \multirow{2}{*}{$\begin{array}{l}\text { Carbapenemase } \\
\text { Oxacilinase }\end{array}$} & & AAGTATTGGGGCTTGTGCTG & & \multirow{2}{*}{$\begin{array}{l}\text { Woodford et al., } \\
2006\end{array}$} \\
\hline & bla $\mathrm{Oxa-58}$ & ССССТСТGCGСТСТАСАTAC & 599 & \\
\hline \multirow{2}{*}{$\begin{array}{c}\text { Carbapenemase } \\
\text { Oxacilinase }\end{array}$} & & AGTTAACTTTCAATAATTG & & \multirow{2}{*}{$\begin{array}{l}\text { Higgins et al., } \\
2009\end{array}$} \\
\hline & bla ${ }_{\text {Oxa-143 }}$ & TTGGAAAATTATATAATCCC & 149 & \\
\hline- & $b^{b l a}$ int1 $_{1}$ & $\begin{array}{l}\text { GCA TCC TCG GTT TTC TGG } \\
\text { GGT GTG GCG GGC TTC GTG }\end{array}$ & 457 & $\begin{array}{l}\text { Shibata et al., } \\
2003\end{array}$ \\
\hline- & $16 S$ & $\begin{array}{l}\text { AGAGTTTGATCCTGGCTCAG } \\
\text { ACGGCTACCTTGTTACGACTT }\end{array}$ & 1499 & $\begin{array}{c}\text { Mendes et al., } \\
2007\end{array}$ \\
\hline
\end{tabular}




\subsection{Reação de sequenciamento}

Após a identificação do gene por meio da PCR, pelo menos um dos produtos gerados para cada reação foi submetido a uma nova reação de PCR com os oligonucleotídeos iniciadores de interesse para seqüenciamento do gene e o produto amplificado foi submetido a purificação pelo kit GFX ${ }^{\mathrm{TM}}$ PCR DNA and Gel Band Purification (Ge healthcare) conforme instruções do fabricante. A quantificação do DNA foi estimada através de uma corrida de eletroforese em um gel de ágarose a $2 \%$ utilizando o peso Low DNA Mass Ladder (Invitrogen). E depois enviado para seqüenciamento.

O seqüenciamento do DNA a partir dos produtos de PCR foi realizado utilizando o MegaBACE 1000, um sistema de análise de DNA de 96 capilares com a tecnologia GE Healthcare. As reações de seqüenciamento foram realizadas de acordo com o protocolo para o MegaBACE 1000, utilizando o DYEnamic ET Dye Terminator Kit (com Thermo Sequenase ${ }^{\mathrm{TM}}$ II DNA Polimerase) código US81090. As sequências foram analisadas pelo software Sequence Analyser utilizando o Base Caller Cimarron 3.12. A seqüência genética foi comparada com banco de dados disponível na internet (BLAST - http://www.ncbi.nlm.nhi.gov/blast/).

\subsection{Protocolo para Tipagem Molecular}

Preparo da suspensão bacteriana: foi repicado as cepas para meio ágar sangue (AS) de carneiro $5 \%$ ou meio TSA, incubou por $18-24 \mathrm{~h}$ a $37^{\circ} \mathrm{C}$. Repicou 3 a 5 colônias do crescimento em AS para tubos contendo $3 \mathrm{~mL}$ TSB e incubou a $37^{\circ} \mathrm{C}$, overnight. Foram pesados e identificados os microtubos a serem utilizados. O crescimento do caldo TSB, foi transferido para os respectivos microtubos. Centrifugou os microtubos por 20 minutos a $11.000 \mathrm{rpm}$. Retirou o sobrenadante e adicionou $1 \mathrm{~mL}$ de solução fisiológica estéril ao sedimento. Foi homogenizado e transferido para os tubos previamente pesados e identificados. Centrifugou por 20 $\mathrm{min}$, a $11.000 \mathrm{rpm}$ e $4^{\circ} \mathrm{C}$. Retirou novamente o sobrenadante e repetiu a lavagem com solução fisiológica estéril por mais duas vezes. Após a última lavagem, 
retirou totalmente o sobrenadante e pesou o microtubo com o sedimento bacteriano. Foi calculada a massa bacteriana obtida e preparou uma suspensão de bactéria na concentração de $100 \mu \mathrm{g} / \mu \mathrm{L}$ em EDTA $25 \mathrm{mM}$ pH8,0.

Preparo dos blocos de ágarose: foi ajustado o banho-maria para temperatura de $56^{\circ} \mathrm{C}$. Fundiu-se a ágarose low melting ( $2 \%$ em TBE 0,5X) e deixou no $\mathrm{BM} 56^{\circ} \mathrm{C}$. Foram identificados os microtubos com os números das amostras e adicionou-se $300 \mu \mathrm{L}$ de tampão TEN e $5 \mu \mathrm{L}$ da suspensão bacteriana $100 \mu \mathrm{g} / \mu \mathrm{L}$. Homogenizou e colocou os microtubos contendo tampão TEN com suspensão bacteriana no banho-maria a $56^{\circ} \mathrm{C}$. Foi adicionado $30 \mu \mathrm{L}$ de Lisozima $20 \mathrm{mg} / \mathrm{mL}$ (somente para Acinetobacter spp) e $340 \mu \mathrm{L}$ de ágarose e foi homogenizado. Foi distribuido essa mistura nos moldes (evitando a formação de bolhas) e deixou por 30 minutos a $4^{\circ} \mathrm{C}$.

Etapa de extração do DNA bacteriano: foi distribuido $2 \mathrm{~mL}$ de tampão EC nos pocinhos que foram usados, em uma placa de cultura de células (24 pocinhos). Removeu os bloquinhos de ágarose dos moldes e colocou nos pocinhos contendo tampão EC. Incubou por $5 \mathrm{~h}$ a $37^{\circ} \mathrm{C}$, sob agitação suave. Retirou o tampão EC e adicionou 2,0mL de tampão CHEF-TE. Retirou o tampão CHEF-TE e novamente adicionou 2,0mL deste tampão. Deixou em temperatura ambiente, sob agitação suave, por 30 minutos. Retirou o tampão CHEF-TE e cobriu os bloquinhos com $2 \mathrm{~mL}$ de tampão ES. Adicionou $100 \mu \mathrm{L}$ de proteinase $\mathrm{K}$ $20 \mathrm{mg} / \mathrm{mL}$ por pocinho e homogeneizou. Foi incubado a $50^{\circ} \mathrm{C}$ overnight. Retirou o tampão ES e lavou 5 vezes com 2,0mL de tampão CHEF-TE. A primeira lavagem não tem incubação e as demais devem ser feitas em intervalos de 1 hora. Após a última lavagem, trocou o tampão CHEF-TE e guardou sob refrigeração. É importante que as lavagens sejam feitas sob leve agitação.

Etapa de restrição enzimática: foi adicionado $300 \mu \mathrm{L}$ de tampão DNS nos pocinhos que foram utilizados, em uma placa de cultura de célula (96 pocinhos). Com auxílio de uma espátula e bisturi, pegou um bloquinho de ágarose que estava no tampão CHEF-TE e cortou ao meio. Foi colocado os pedaços no pocinho contendo DNS. Retirou o tampão DNS. Lavou 5 vezes com tampão DNS, 
com incubações de 1 hora por lavagem. Retirou o tampão DNS e substituiu com $200 \mu \mathrm{L}$ de tampão da enzima (sem enzima). Incubou a $5^{\circ} \mathrm{C}$ por 1 hora. Removou 0 tampão da enzima e adicionou o tampão da enzima com a enzima de restrição (10U por amostra). Incubou a $5^{\circ} \mathrm{C}$ por 1 a $2 \mathrm{~h}$. Retirou da geladeira e incubou nas condições indicadas pelo fabricante, por um período de 15 horas. As enzimas de restrição usadas neste estudo foram Smal para cepas de Acinetobacter spp e Spel para cepas de $P$. aeruginosa.

Preparo do gel: foi preparada uma ágarose 1\% em TBE 0,5X. Aplicou os bloquinhos no gel e vedou com ágarose 1\%. Preparou 2 litros de TBE 0,5X e acrescentou $200 \mu \mathrm{L}$ de tiouréia $0,5 \mathrm{M}$. Colocou o tampão na cuba e ajustou as condições de corrida de acordo com a Tabela 2.

Tabela 2 - Condições de corrida para PFGE

\begin{tabular}{c|c|c|c|c|c}
\hline $\begin{array}{c}\text { Micro } \\
\text { organismos }\end{array}$ & $\begin{array}{c}\text { Ágarose } \\
(\%)\end{array}$ & $\begin{array}{c}\text { Switch Time } \\
\text { inicial-final }\end{array}$ & $\begin{array}{c}\text { Volts/ } \\
\mathrm{cm}\end{array}$ & $\begin{array}{c}\text { Tempo } \\
\text { de corrida }\end{array}$ & $\begin{array}{c}\text { Separação dos } \\
\text { fragmentos em Kb }\end{array}$ \\
\hline $\boldsymbol{P}$. aeruginosa & 1 & $5,0-90,0$ & 6 & $24 \mathrm{hs}$ & $100-650$ \\
\hline Acinetobacter spp & 1 & $5,0-30,0$ & 6 & $23 \mathrm{hs}$ & $<50-350$ \\
\hline
\end{tabular}

\section{Interpretação dos resultados}

Os perfis moleculares foram analisados visualmente, seguindo os critérios de Tenover et al. (1997), conforme a Tabela 3 . 
Tabela 3 - Critérios interpretativos para análise de tipagem molecular

\begin{tabular}{cccc}
\hline $\begin{array}{c}\text { Interpretação } \\
\text { microbiológica } \\
\text { baseada nos } \\
\text { resultados de } \\
\text { tipagem }\end{array}$ & $\begin{array}{c}\text { Número de } \\
\text { diferenças genéticas } \\
\text { comparadas com } \\
\text { um determinado } \\
\text { isolado }\end{array}$ & $\begin{array}{c}\text { Número de fragmentos } \\
\text { diferentes comparados } \\
\text { ao padrão de } \\
\text { determinado isolado }\end{array}$ & $\begin{array}{c}\text { Correlação } \\
\text { epidemiológica }\end{array}$ \\
\hline $\begin{array}{c}\text { Indistinguíveis } \\
\text { Estreitamente } \\
\text { relacionados }\end{array}$ & 0 & 0 & $\begin{array}{c}\text { Isolado faz parte } \\
\text { do surto }\end{array}$ \\
\hline $\begin{array}{c}\text { Possivelmente } \\
\text { relacionados }\end{array}$ & 1 & $2-3$ & $\begin{array}{c}\text { Isolado } \\
\text { provavelmente faz } \\
\text { parte do surto }\end{array}$ \\
\hline Diferentes & 2 & $4-6$ & $\begin{array}{c}\text { Isolado } \\
\text { possivelmente faz } \\
\text { parte do surto }\end{array}$ \\
\hline
\end{tabular}




\subsection{Fluxograma das atividades}

$P$. aeruginosa Acinetobacter spp.

Isolados de sangue

resistentes

carbapenêmicos pelo
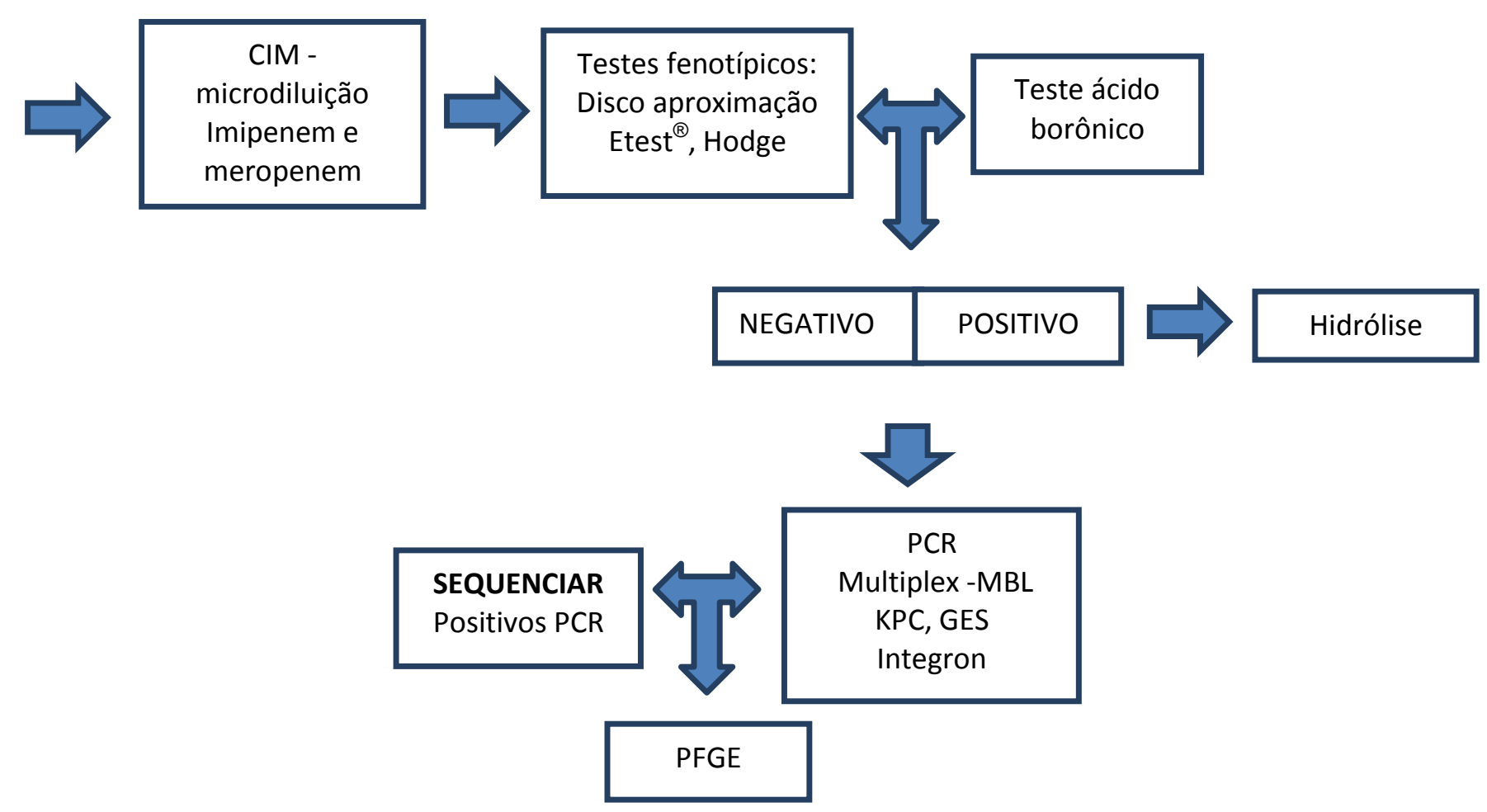


\section{RESULTADOS}

\subsection{Amostras bacterianas}

As 108 cepas foram identificadas como $P$. aeruginosa multiresistentes de pacientes com infecção de corrente sanguínea do ano de 1998 a 2009.

As cepas de Acinetobacter spp foram identificadas como pertencentes ao complexo A. calcoaceticus - A. baumannii.

As Figuras 2 e 3 mostram os gráficos com a distribuição das amostras de $P$. aeruginosa e Acinetobacter spp. de acordo com o ano de isolamento e unidade de internação do Hospital das Clínicas - FMUSP.

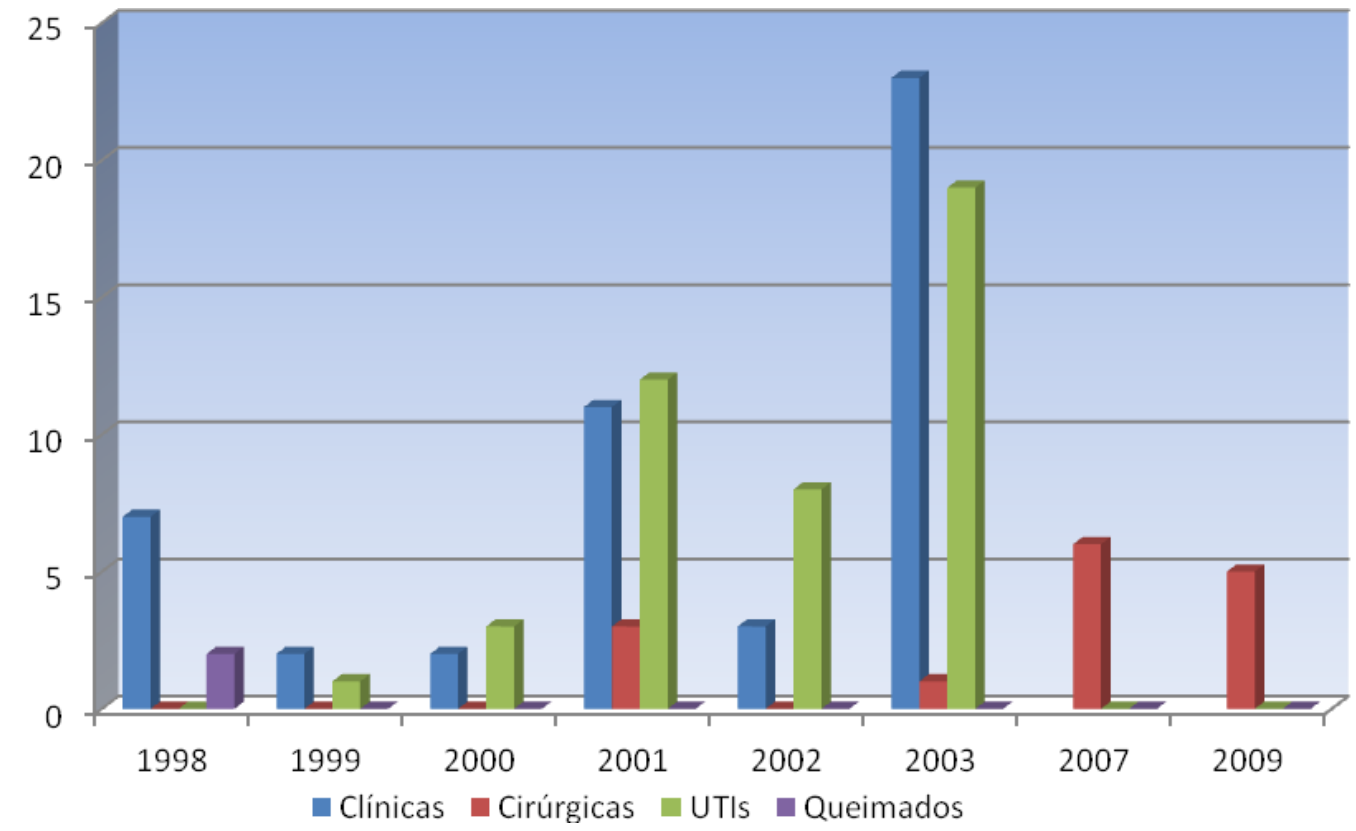

Figura 2 - Gráfico ilustrativo da distribuição das 108 amostras de $P$. aeruginosa de acordo com o ano de isolamento. 


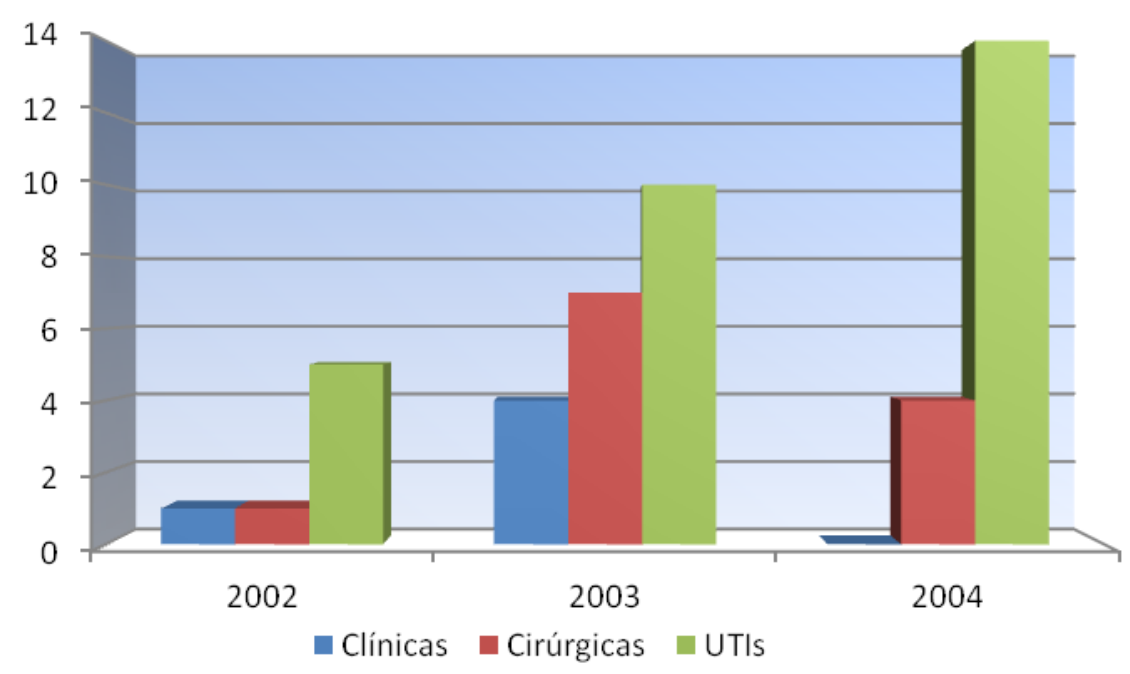

Figura 3 - Gráfico ilustrativo da distribuição das 50 amostras de Acinetobacter sp. de acordo com o ano de isolamento.

\subsection{Perfil de sensibilidade}

Foram determinadas as CIM de dois antimicrobianos, imipenem e meropenem para os isolados de $P$. aerugionosa e Acinetobacter $s p$., até a concentração de $256 \mu \mathrm{g} / \mathrm{mL}$.

Todos os isolados foram resistentes aos carbapenêmicos. Os resultados da $\mathrm{CIM}_{50}$ e $\mathrm{CIM}_{90}$ das $P$. aeruginosa foram respectivamente $64 \mu \mathrm{g} / \mathrm{ml}$ e $256 \mu \mathrm{g} / \mathrm{ml}$ para imipenem e $32 \mu \mathrm{g} / \mathrm{ml}$ e $256 \mu \mathrm{g} / \mathrm{ml}$ para meropenem.

As CIM $_{50}$ e CIM $_{90}$ dos Acinetobacter spp foram $64 \mu \mathrm{g} / \mathrm{ml}$ e $128 \mu \mathrm{g} / \mathrm{ml}$ para imipenem e $128 \mu \mathrm{g} / \mathrm{ml}$ para meropenem. 
Tabela 4 - Porcentagem cumulativa das CIMs para os isolados de $P$. aeruginosa e Acinetobacter spp. em relação aos antimicrobianos imipenem e meropenem

\begin{tabular}{ccccccccccc}
\hline $\begin{array}{c}\text { Microrganismo/no } \\
\text { isolados }\end{array}$ & \multicolumn{8}{c}{ Número de isolados/ CIM - $\boldsymbol{\mu g} / \mathbf{m L}$} \\
\hline $\begin{array}{c}\text { P. aeruginosa (108) } \\
\text { Imipenem }\end{array}$ & $\mathbf{2}$ & $\mathbf{4}$ & $\mathbf{8}$ & $\mathbf{1 6}$ & $\mathbf{3 2}$ & $\mathbf{6 4}$ & $\mathbf{1 2 8}$ & $\mathbf{2 5 6}$ & $>\mathbf{2 5 6}$ \\
\hline $\begin{array}{c}\text { Meropenem } \\
\text { Acinetobacter spp. (50) } \\
\text { Imipenem }\end{array}$ & $1(0,9 \%)$ & $1(1,8)$ & $5(6,4)$ & $26(30,5)$ & $31(59,3)$ & $15(73,2)$ & $2(75,0)$ & $7(81,5)$ & $20(100,0)$ \\
\hline Meropenem & - & - & - & $7(14,0)$ & $14(42,0)$ & $16(74,0)$ & $12(98,0)$ & $1(100,0)$ & - \\
\hline
\end{tabular}

\subsection{Reações de amplificação em cadeia da polimerase (PCR)}

\subsubsection{Reação de amplificação em cadeia da polimerase (PCR) multiplex para detecção de genes codificadores de Metalo- $\beta$-lactamase}

Os genes codificadores de $M \beta L$ foram detectados pela técnica de PCR multiplex em apenas vinte e cinco $(23,2 \%)$ dos isolados de $P$. aeruginosa. $O$ gene bla $a_{\mathrm{SPM}}$ foi o mais freqüente, sendo identificado em vinte um isolados $(19,4 \%)$, o gene blavim em quatro isolados $(3,7 \%)$ e o genes bla $a_{\mathrm{IMP}}$, bla $a_{\mathrm{GIM}}$, bla $a_{\mathrm{SIM}}$ e bla $a_{\mathrm{NDM}}$ não foram identificados.

Apenas cinco isolados (10\%) de Acinetobacter spp apresentaram o gene bla IMP e nenhum apresentou a presença de outros genes codificadores de M $\beta \mathrm{L}$. 


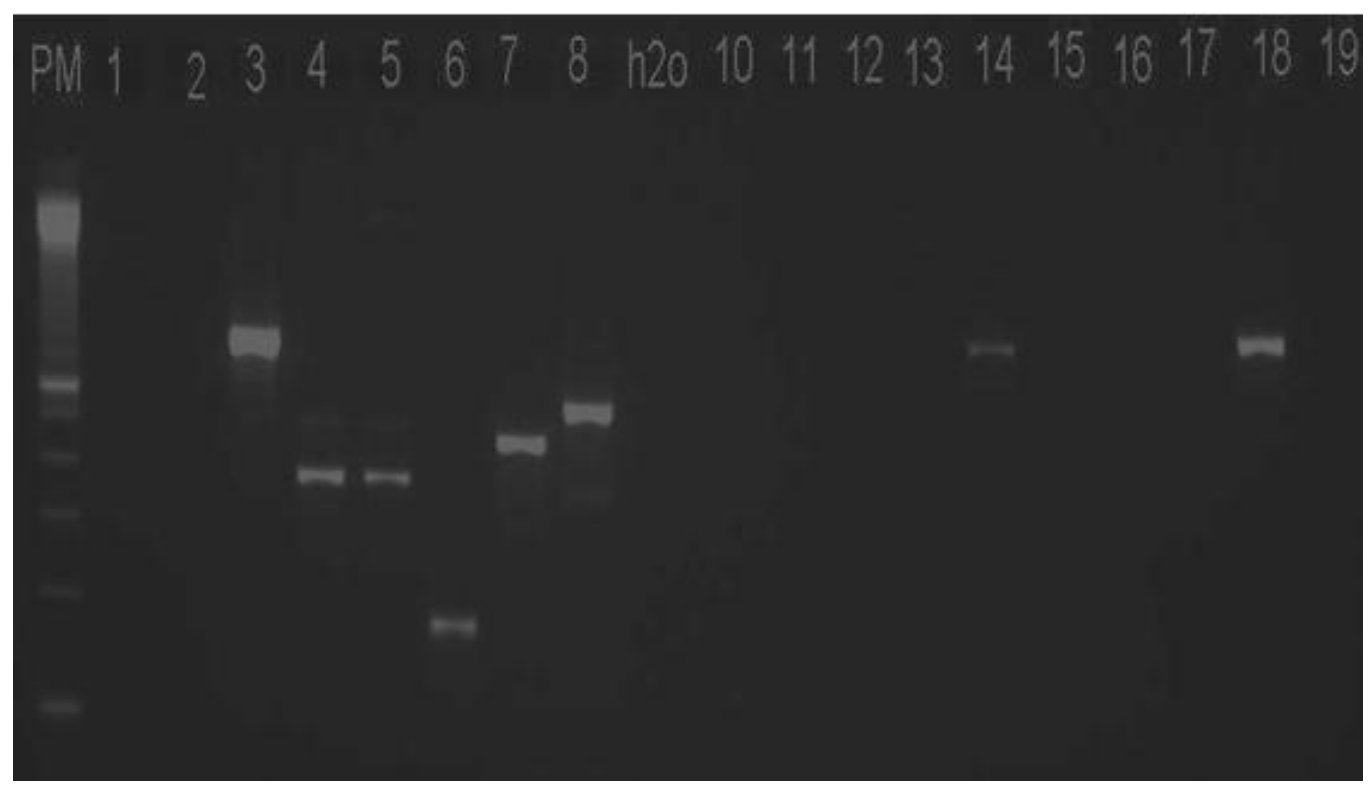

NOTA: colunas 1 e 2 - controles negativos, coluna 3 - controle positivo para o gene blaSPM, colunas 4 e 5 - controles positivos para os genes blaVIM-1 e gene blaVIM-2 , coluna 6 -controle positivo para o gene blalMP, coluna 7 - controle positivo para o gene blaGIM, coluna 8- controle positivo para o gene blaSIM, colunas 14 e 18 isolados positivos para os genes blaSPM, colunas 10,11,12,13,15,16,17 e 19 isolados negativos.

Figura 4 - Gel de eletroforese - Multiplex PCR para detecção dos genes de M $\beta L$ isolados de $P$. aeruginosa.

Uma amostra de cada cepa positiva no PCR para gene codificador M $\beta L$ foi submetida para reação de seqüenciamento e após comparação com o banco de dados (BLAST - http://www.ncbi.nlm.nhi.gov/blast/), obtivemos: SPM-1, IMP-1 e VIM-2. 
Tabela 5 - Resultados da concentração inibitória mínima (CIM) dos isolados e o tipo de gene codificador $M \beta L$.

\begin{tabular}{|c|c|c|c|c|}
\hline Microrgainsmos & $\begin{array}{l}\text { Número } \\
\text { da cepa }\end{array}$ & $\begin{array}{l}\text { CIM IMP } \\
(\mu \mathrm{g} / \mathrm{mL})\end{array}$ & $\begin{array}{c}\text { CIM MERO } \\
(\mu \mathrm{g} / \mathrm{mL})\end{array}$ & Gene \\
\hline \multirow{5}{*}{ Acinetobacter spp. } & 6 & 128,0 & 128,0 & IMP \\
\hline & 7 & 128,0 & 64,0 & IMP \\
\hline & 30 & 256,0 & 64,0 & IMP \\
\hline & 43 & 128,0 & 128,0 & IMP \\
\hline & 52 & 16,0 & 32,0 & IMP \\
\hline \multirow{25}{*}{ 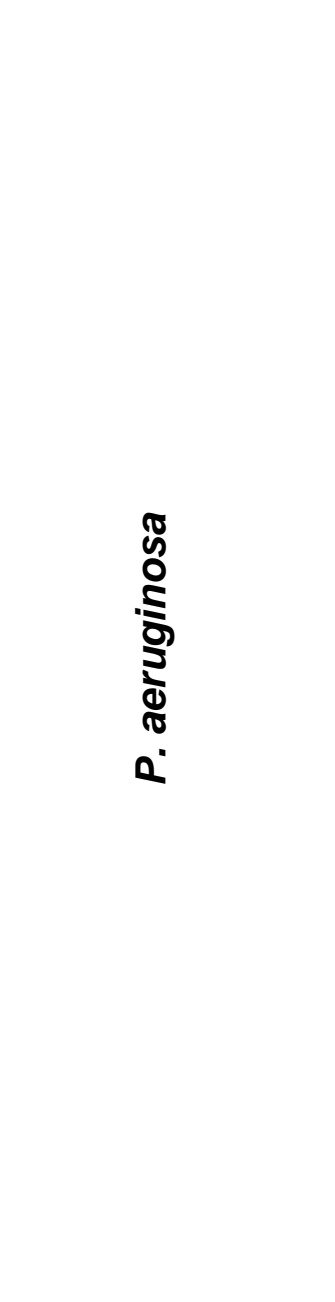 } & 23 & 64,0 & 16,0 & VIM \\
\hline & 81 & 64,0 & 128,0 & VIM \\
\hline & $3 / 09$ & $>256$ & $>256$ & VIM \\
\hline & $5 / 09$ & $>256$ & $>256$ & VIM \\
\hline & 1 & $>256$ & $>256$ & SPM \\
\hline & 2 & $>256$ & $>256$ & SPM \\
\hline & 17 & $>256$ & $>256$ & SPM \\
\hline & 45 & $>256$ & $>256$ & SPM \\
\hline & 57 & $>256$ & $>256$ & SPM \\
\hline & 62 & $>256$ & $>256$ & SPM \\
\hline & 74 & 256,0 & $>256$ & SPM \\
\hline & 85 & $>256$ & $>256$ & SPM \\
\hline & 86 & 128,0 & 16,0 & SPM \\
\hline & 105 & 256,0 & $>256$ & SPM \\
\hline & 107 & $>256$ & 256,0 & SPM \\
\hline & 109 & $>256$ & 256,0 & SPM \\
\hline & $1 / 07$ & $>256$ & $>256$ & SPM \\
\hline & $3 / 07$ & $>256$ & $>256$ & SPM \\
\hline & $6 / 07$ & $>256$ & $>256$ & SPM \\
\hline & $8 / 07$ & $>256$ & $>256$ & SPM \\
\hline & $9 / 07$ & $>256$ & $>256$ & SPM \\
\hline & $12 / 07$ & $>256$ & $>256$ & SPM \\
\hline & $1 / 09$ & $>256$ & $>256$ & SPM \\
\hline & $8 / 09$ & $>256$ & $>256$ & SPM \\
\hline & $9 / 09$ & $>256$ & $>256$ & SPM \\
\hline
\end{tabular}

NOTA: IMP: imepenem, MERO: meropenem 


\subsubsection{Reação de amplificação em cadeia da polimerase (PCR) para oxacilinases}

Para detecção dos genes de oxacilinases foram realizadas PCRs com primers específicos para os 50 isolados de Acinetobacter baumannii. Nove isolados (18\%) apresentaram positividade para o grupo OXA-23, quarenta nove isolados (98\%) apresentaram positividade para o grupo OXA-51, trinta oito isolados $(76 \%)$ apresentaram positividade para o grupo OXA-143.

A amostra que não apresentou a banda especifica para o gene bla oxa-51, foi considerada pertencente ao grupo $A$. calcoaceticus, após ser submetida a uma reação de PCR para seqüenciamento do gene $16 \mathrm{~S}$ e analisada no programa BLAST.

Tabela 6 - Relação entre os perfis de sensibilidade para imipenem (IMP) e meropenem (MERO) para os genes codificadores de M $\beta L$ e oxacilinases em isolados de Acinetobacter spp.

\begin{tabular}{|c|c|c|c|c|c|}
\hline \multirow{2}{*}{ CIM IMP/MERO (ug/mL) } & \multicolumn{4}{|c|}{ GENE } & \multirow[b]{2}{*}{ bla $a_{0 \times a 143}$} \\
\hline & blaoxA 23/51 & bla OXA 51 & $b / a_{\mathrm{IMP} / \mathrm{OXA}} 51$ & $b / a_{\mathrm{MP}}$ & \\
\hline $16 / 16$ & 1 & 0 & 0 & 0 & 1 \\
\hline $16 / 32$ & 3 & 0 & 0 & 1 & 4 \\
\hline $16 / 128$ & 0 & 2 & 0 & 0 & 2 \\
\hline $32 / 32$ & 1 & 0 & 0 & 0 & 0 \\
\hline $32 / 64$ & 2 & 2 & 0 & 0 & 3 \\
\hline $32 / 128$ & 0 & 3 & 0 & 0 & 3 \\
\hline $32 / 256$ & 0 & 6 & 0 & 0 & 5 \\
\hline $64 / 64$ & 1 & 1 & 0 & 0 & 1 \\
\hline $64 / 128$ & 1 & 7 & 0 & 0 & 5 \\
\hline $64 / 256$ & 0 & 6 & 0 & 0 & 6 \\
\hline $128 / 64$ & 0 & 1 & 1 & 0 & 0 \\
\hline $128 / 128$ & 0 & 3 & 2 & 0 & 2 \\
\hline $128 / 256$ & 0 & 5 & 0 & 0 & 5 \\
\hline $256 / 64$ & 0 & 0 & 0 & 0 & 1 \\
\hline $256 / 256$ & 0 & 0 & 1 & 0 & 0 \\
\hline TOTAL & 9 & 36 & 4 & 1 & 38 \\
\hline
\end{tabular}




\subsubsection{Reação de amplificação em cadeia da polimerase (PCR) para outras carbapenemases}

Para a detecção das carbapenemases GES e KPC, foram realizadas PCRs com primers específicos.

Para os isolados $P$. aeruginosa foram identificadas quatro cepas positivas $(3,7 \%)$ para o gene GES e nenhum isolado de Acinetobacter spp foi codificado para essa enzima. As amostras dos isolados positivos no PCR foi submetida para reação de seqüenciamento e após comparação com o banco de dados (BLAST http://www.ncbi.nlm.nhi.gov/blast/), todas foram confirmadas como GES-5.

Nenhuma das amostras de $P$. aeruginosa e Acinetobacter spp avaliadas nesse estudo apresentou positividade para o gene KPC.

Tabela 7 - Resultados da concentração inibitória mínima (CIM) dos isolados de $P$. aeruginosa positivos para o gene GES

Microrganismos

Amostras

CIM IMP $(\mu \mathrm{g} / \mathrm{mL})$

CIM MERO ( $\mu \mathrm{g} / \mathrm{mL})$

Gene

\begin{tabular}{lllll}
\hline & 28 & 64,0 & 256,0 & GES \\
P. aeruginosa & 29 & 64,0 & 256,0 & GES \\
& 30 & 64,0 & 256,0 & GES \\
& 82 & 64,0 & 128,0 & GES \\
\hline
\end{tabular}

NOTA: IMP: Imepenem, MERO: meropenem 


\subsubsection{Reação de amplificação em cadeia da polimerase (PCR) para gene codificador intl-1}

Das 108 amostras de Pseudomonas aeruginosa, catorze amostra (12,9\%) deram positivo para o gene bla intl-1, quatro $(3,7 \%)$ dessas amostras foram positivas para o gene codificador blavim e quatro $(3,7 \%)$ para gene bla Acinetobacter spp não foi encontrado nenhum gene.

Tabela 8 - Resultados das CIMs de imipenem e meropenem dos isolados de Pseudomonas aeruginosa epresença dos genes codificadores de carbapenemases e a presença do gene intl1

\begin{tabular}{ccccc}
\hline No da cepa & IMP $(\boldsymbol{\mu g} / \mathbf{m L})$ & MERO $(\boldsymbol{\mu g} / \mathbf{m L})$ & Carbapenemase & IntI-1 \\
\hline 23 & 64 & 16 & VIM & positivo \\
81 & 64 & 128 & VIM & positivo \\
$3 / 09$ & $>256$ & $>256$ & VIM & positivo \\
$5 / 09$ & $>256$ & $>256$ & VIM & positivo \\
28 & 64 & 256 & GES & positivo \\
29 & 64 & 256 & GES & positivo \\
30 & 64 & 256 & GES & positivo \\
32 & 64 & 128 & GES & positivo \\
\hline
\end{tabular}

\subsection{Análise do polimorfismo do DNA por eletroforese em campo pulsado (PFGE)}

Analisando visualmente os perfis de DNA gerados por PFGE, de acordo com os critérios propostos por Tenover (1995), foram obtidos 15 perfis diferentes em 9 clusters do total de 108 isolados de $P$. aeruginosa, vinte sete (25\%) apresentaram o mesmo padrão molecular, denominado de padrão predominante ou padrão (A1). Trinta e dois $(29,7 \%)$ mostraram-se estreitamente relacionados ao padrão predominante (A2), 16 (14,8\%) possivelmente relacionado ao padrão predominante (A3) e $33(30,5 \%)$ dos isolados não mostraram nenhuma relação com o padrão predominante. 
Nove isolados (43\%) dos 21 isolados de $P$. aeruginosa positivos para o gene codificador de SPM pertenciam a um clone predominante e os isolados com gene codificador de VIM apresentaram diferentes clones. (Figura 5)

Dos 50 isolados de Acinetobacter spp, foram obtidos 21 perfis diferentes em 10 clusters, sendo que 7 (14\%) apresentaram um mesmo padrão molecular, denominado de clone predominante ou padrão (A1). Seis (12\%) dos isolados mostraram-se estreitamente relacionados ao padrão predominante (A2), $18(36 \%)$ mostraram-se estreitamente relacionados ao padrão predominante (A3) e 19 (38\%) dos isolados não mostraram nenhuma relação com o padrão predominante.

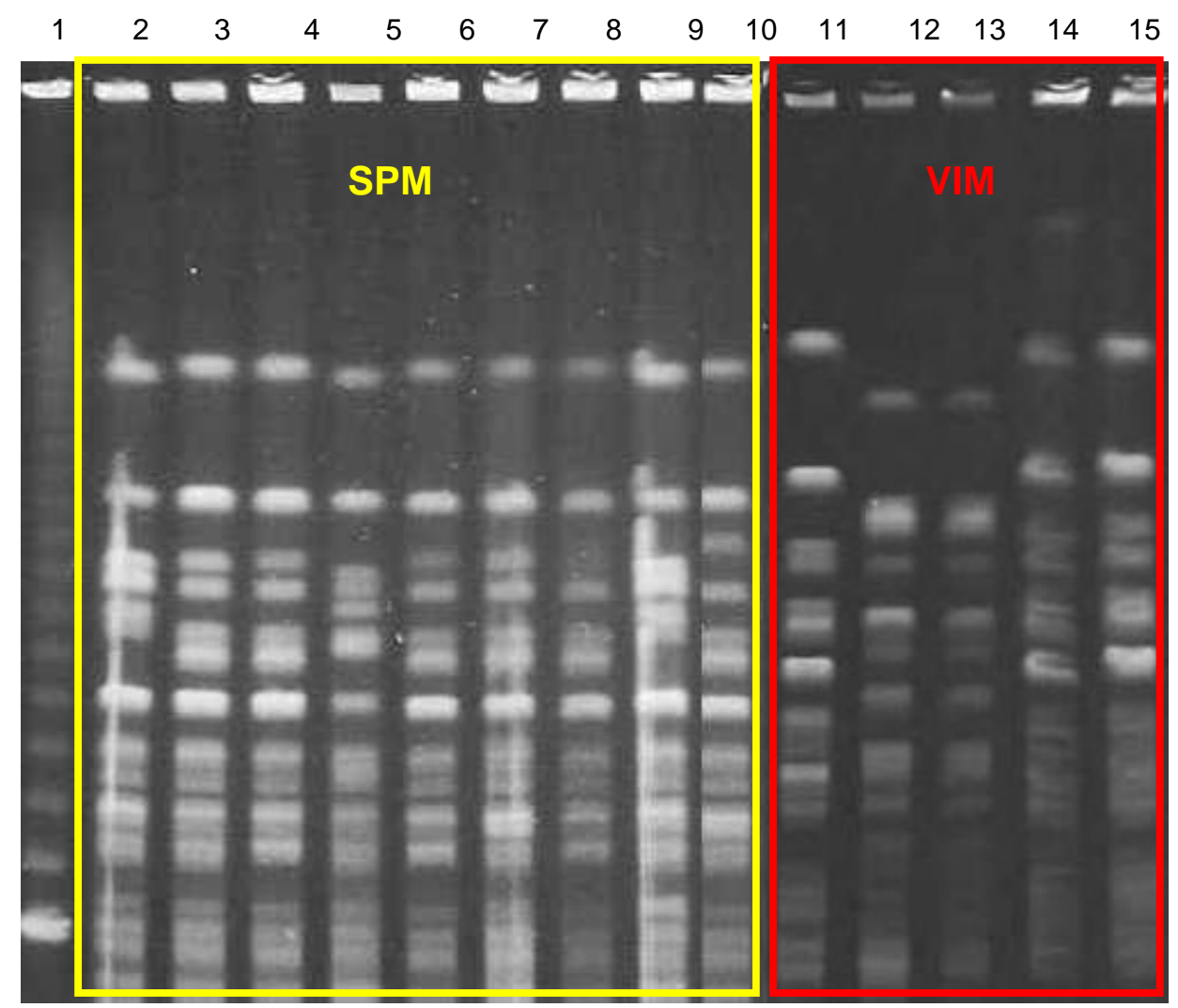

NOTA: Coluna 1 - Peso molecular, coluna 2 a 10 positivas para SPM, coluna 11 a 15 positivas para VIM.

Figura 5 - Representação do perfil de bandas obtidos a partir do método PFGE em isolados $P$. aeruginosa após utilização da enzima Spe-I. 
Tabela 9 - Análise molecular dos 108 isolados de $P$. aeruginosa multirresistentes, realizada de acordo com critérios propostos por Tenover et al. (1995)

\begin{tabular}{cc}
\hline Padrão Molecular & Número de isolados \\
\hline Padrão A & $27(25 \%)$ \\
Estreitamente relacionados & $32(29,7 \%)$ \\
Possivelmente relacionados & $16(14,8 \%)$ \\
Diferentes & $33(30,5 \%)$ \\
\hline
\end{tabular}

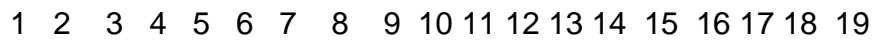

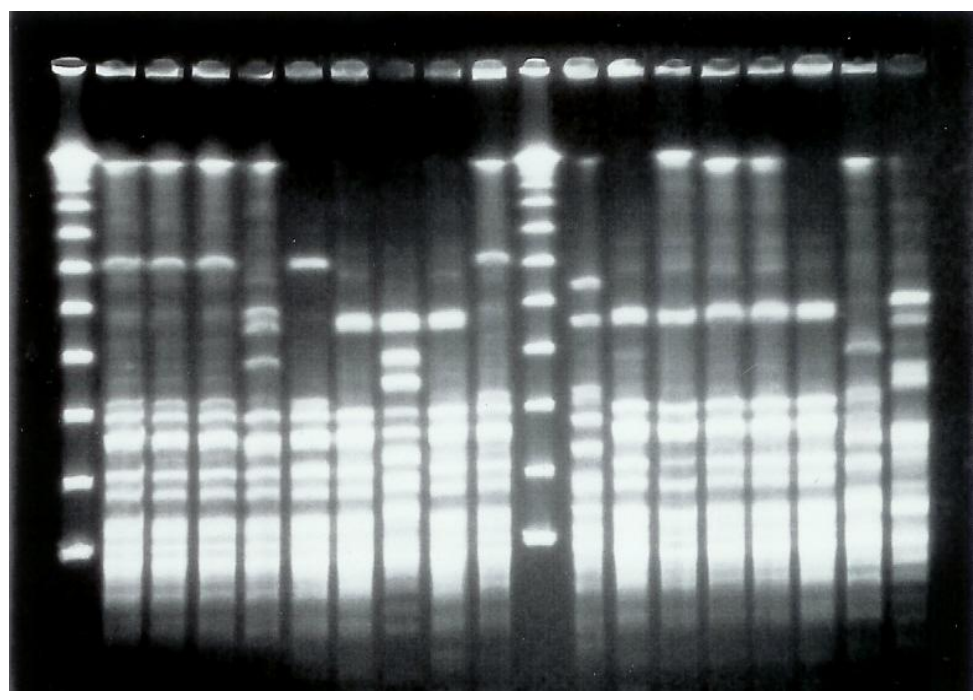

Figura 6 - Representação do perfil de bandas obtido a partir do método de eletroforese em campo pulsado, utilizando-se a enzima de restrição Smal em amostras de Acinetobacter spp.= 
Tabela 10 - Análise molecular dos 50 isolados de Acinetobacter spp, realizada de acordo com critérios propostos por Tenover et al. (1995).

\begin{tabular}{cc}
\hline Padrão Molecular & Número de isolados \\
\hline Padrão A & $7(14 \%)$ \\
Estreitamente relacionados & $6(12 \%)$ \\
Possivelmente relacionados & $18(36 \%)$ \\
Diferentes & $19(38 \%)$ \\
\hline
\end{tabular}

\subsection{Detecção fenotípica de Metalo- $\beta$-lactamase pelo método do Etest ${ }^{\circledR}$}

Todas as amostras foram testadas com fitas de Etest ${ }^{\circledR}$ para $M \beta L$, onde uma extremidade contém imipenem (IP) e na outra imipenem associado com EDTA (IPI) demonstrado na figura 2 (AB Biodisk (North América Inc., N.J.) e foram seguidos os critérios propostos por Walsh et al. (2002). Das 108 amostras de $P$. aeruginosa, oitenta e três foram positivas (76,8\%) e das 50 amostras de Acinetobacter spp, quarenta e cinco foram positivas (90\%).

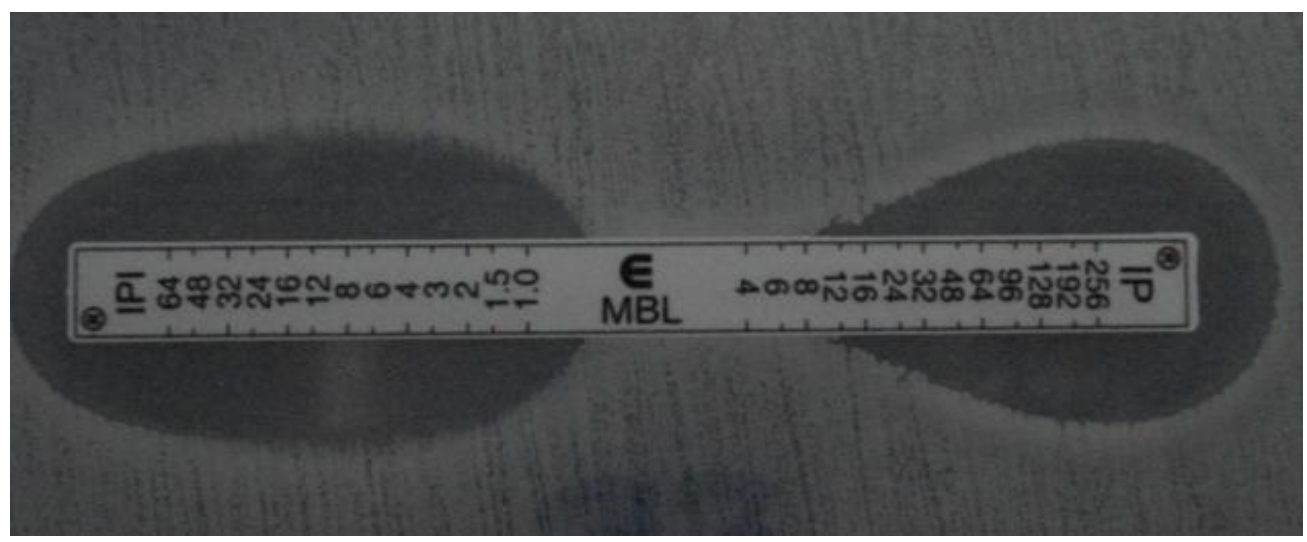

Figura 7 - Determinação da concentração inibitória mínima e detecção Metalo- $\beta$ lactamase por fita de Etest ${ }^{\circledR}$ de uma amostra clínica de $P$. aeruginosa. 
A partir da comparação com o padrão ouro ("gold standard") PCR para os genes $\mathrm{M} \beta \mathrm{L}$, observou que o Etest $^{\circledR}$ tem $100 \%$ sensibilidade, conforme mostra Tabela 11.

Também foram comparados os genes das oxacilinases encontradas nos Acinetobacter spp com a fita de Etest ${ }^{\circledR}$ para $\mathrm{M} \beta \mathrm{L}$, observando-se uma sensibilidade de $92,1 \%$ e uma especificidade de 8,3\%, conforme a Tabela 12.

Tabela 11 - Comparação entre a metodologia de Etest ${ }^{\circledR}$ com o padrão ouro (PCR) para isolados de Acinetobacter spp e $P$. aeruginosa positivos para o gene MßL.

\begin{tabular}{|c|c|c|c|}
\hline Resultados Etest ${ }^{\circledR} M \beta L$ & $\begin{array}{c}\text { PCR (+) } \\
\text { gene M } \beta L\end{array}$ & $\begin{array}{c}\text { PCR (-) } \\
\text { gene M } \beta L\end{array}$ & Valores \\
\hline
\end{tabular}

Acinetobacter spp

\begin{tabular}{|c|c|c|c|c|}
\hline Positivo & 5 & 41 & $\begin{array}{l}\text { Sensibilidade } \\
\text { Especificidade }\end{array}$ & $\begin{array}{r}100,00 \% \\
8,89 \%\end{array}$ \\
\hline \multirow{2}{*}{ Negativo } & \multirow{2}{*}{0} & \multirow{2}{*}{4} & VPP & $10,87 \%$ \\
\hline & & & VPN & $100,00 \%$ \\
\hline \multicolumn{5}{|c|}{ P. aeruginosa } \\
\hline \multirow{2}{*}{ Positivo } & \multirow{2}{*}{25} & \multirow{2}{*}{67} & Sensibilidade & $100,00 \%$ \\
\hline & & & Especificidade & $19,28 \%$ \\
\hline \multirow{2}{*}{ Negativo } & \multirow{2}{*}{0} & \multirow{2}{*}{16} & VPP & $27,17 \%$ \\
\hline & & & VPN & $100,00 \%$ \\
\hline
\end{tabular}

NOTA: VPN: valor preditivo negativo; VPP: valor preditivo positivo 
Tabela 12 - Comparação entre a metodologia de Etest ${ }^{\circledR}$ com o padrão ouro (PCR) para isolados de Acinetobacter spp. positivos para os genes oxacilinases

\begin{tabular}{|c|c|c|c|c|}
\hline $\begin{array}{c}\text { Resultados Etest }{ }^{\circledR} \\
\text { M } \beta L\end{array}$ & $\begin{array}{c}\text { PCR (+) } \\
\text { gene M } \beta L\end{array}$ & $\begin{array}{c}\text { PCR (-) } \\
\text { gene M } \beta L\end{array}$ & \multicolumn{2}{|c|}{ Valores } \\
\hline \multirow{2}{*}{ Positivo } & \multirow{2}{*}{35} & \multirow{2}{*}{11} & Sensibilidade & $92,10 \%$ \\
\hline & & & Especificidade & $8,33 \%$ \\
\hline \multirow{2}{*}{ Negativo } & \multirow{2}{*}{3} & \multirow{2}{*}{1} & VPP & $76,09 \%$ \\
\hline & & & VPN & $25,00 \%$ \\
\hline
\end{tabular}

NOTA: VPN: valor preditivo negativo; VPP: valor preditivo positivo

\subsection{Detecção fenotípica de Metalo- $\beta$-lactamase pelo método de aproximação de disco}

$\mathrm{Na}$ detecção de Metalo- $\beta$-lactamase pelo método de aproximação de disco proposto por Arakawa et al., os resultados descritos na Tabela 14.

O teste de aproximação do antibiótico imipenem com um disco impregnado com $3 \mu \mathrm{l}$ do $\beta$-mercaptoetanol foi o que apresentou maior sensibilidade $100 \%$ e especificidade $71 \%$, valor preditivo positivo de $28 \%$ e valor preditivo negativo de $100 \%$ para detectar M $\beta \mathrm{L}$ em isolados Acinetobacter spp.

Para os isolados de $P$. aeruginosa, positivos para os genes codificadores de SPM e VIM, o método que melhor resultado apresentou foi a diferença $\geq 8 \mathrm{~mm}$ entre IM e IMPE, sensibilidade de $72 \%$ e uma especificidade $73 \%$, valor preditivo positivo $44 \%$ e valor preditivo negativo $89 \%$.

Tabela 13 - Comparação de duas técnicas fenotípicas com a medotologia padrão ouro - PCR para a detecção da produção de $\mathrm{M} \beta \mathrm{L}$ em isolados de $P$. aeruginosa e Acinetobacter spp. 


\begin{tabular}{|c|c|c|c|c|c|}
\hline \multirow{2}{*}{ Resultados } & \multicolumn{2}{|c|}{$\begin{array}{c}\text { Aproximação } \\
\text { com IMP (DDST) }\end{array}$} & \multicolumn{2}{|c|}{$\begin{array}{l}\text { Aproximação com } \\
\text { CAZ (DDST) }\end{array}$} & \multirow{2}{*}{$\begin{array}{l}\text { Diferença } \\
\geq 8 \mathrm{~mm} \text { entre } \\
\text { IMP e IMPE }\end{array}$} \\
\hline & EDTA & ABM & EDTA & ABM & \\
\hline \multicolumn{6}{|l|}{ Acinetobacter spp. $(n=50)$} \\
\hline $\begin{array}{l}\text { Sensibilidade } \\
\text { Especificidade }\end{array}$ & $\begin{array}{c}40 \% \\
100 \%\end{array}$ & $\begin{array}{l}100 \% \\
71 \%\end{array}$ & $\begin{array}{c}0 \% \\
91 \%\end{array}$ & $\begin{array}{l}40 \% \\
98 \%\end{array}$ & $\begin{array}{l}100 \% \\
40 \%\end{array}$ \\
\hline $\begin{array}{l}\text { Valor preditivo positivo } \\
\text { Valor preditivo negativo }\end{array}$ & $\begin{array}{l}100 \% \\
93 \% \\
\end{array}$ & $\begin{array}{l}28 \% \\
100 \% \\
\end{array}$ & $\begin{array}{l}0 \% \\
89 \% \\
\end{array}$ & $\begin{array}{l}66 \% \\
93 \% \\
\end{array}$ & $\begin{array}{l}16 \% \\
100 \% \\
\end{array}$ \\
\hline \multicolumn{6}{|c|}{ Pseudomonas aeruginosa $(n=108)$} \\
\hline $\begin{array}{l}\text { Sensibilidade } \\
\text { Especificidade }\end{array}$ & $\begin{array}{l}32 \% \\
97 \%\end{array}$ & $\begin{array}{l}8 \% \\
98 \%\end{array}$ & $\begin{array}{l}48 \% \\
92 \%\end{array}$ & $\begin{array}{l}16 \% \\
92 \%\end{array}$ & $\begin{array}{l}72 \% \\
73 \%\end{array}$ \\
\hline $\begin{array}{l}\text { Valor preditivo positivo } \\
\text { Valor preditivo negativo }\end{array}$ & $\begin{array}{l}80 \% \\
83 \%\end{array}$ & $\begin{array}{l}50 \% \\
78 \%\end{array}$ & $\begin{array}{l}67 \% \\
86 \%\end{array}$ & $\begin{array}{l}40 \% \\
79 \%\end{array}$ & $\begin{array}{l}44 \% \\
89 \%\end{array}$ \\
\hline
\end{tabular}

Nota: $\overline{E D T A}=$ Ácido etilenodiamino tetra-acético; ABM = Ácido $\beta$-mercaptoetanol $\mathrm{IMI}=$ imipenem; $\mathrm{MERO}=$ meropenem; DDST: teste do duplo disco sinergismo

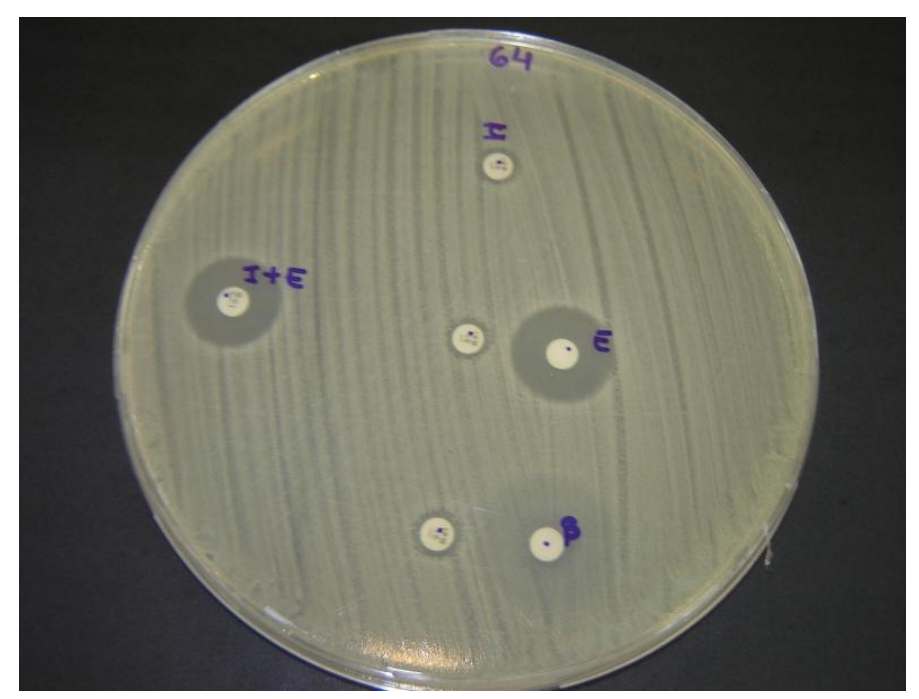

NOTA: Teste positivo para diferenciação de halo $\mathrm{I}+\mathrm{E} \geq 8 \mathrm{~mm}$ quando comparado com I. $\mathrm{E}$ : Ácido etilenodiamino tetra-acético (EDTA); I: Imipenem; $\beta$ : Ácido $\beta$-mercaptoetanol

Figura 8 - Teste de aproximação de disco imipenem com os inibidores e comparação da diferenciação de halo do disco IMI com I+E 


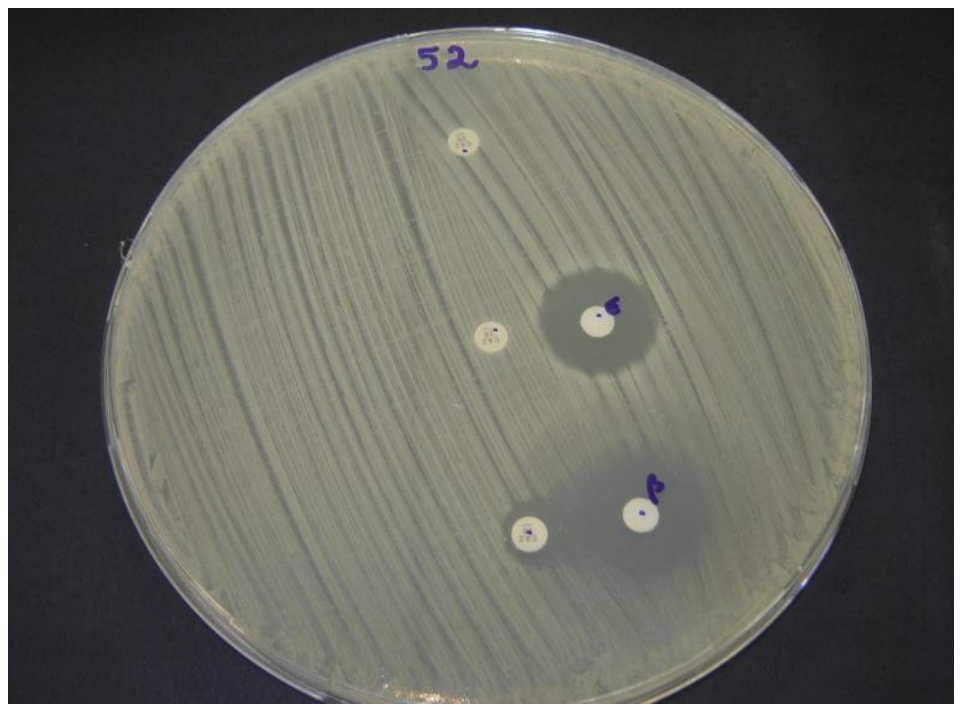

NOTA: Teste positivo para CAZ/ABM. CAZ: ceftazidima; E: Ácido etilenodiamino tetraacético (EDTA); $\beta$ : Ácido $\beta$-mercaptoetanol (ABM)

Figura 9 - Teste de aproximação de disco ceftazidima com os inibidores EDTA e ABM

\subsection{Detecção de Carbapenemases pelo método de Hodge modificado (Lee et al., 2001)}

Dos 50 isolados de Acinetobacter spp analisados, 19 foram negativos e 31 isolados foram positivos para o teste. Para os isolados de $P$. aeruginosa seis foram positivos e 102 isolados foram negativos.

Comparando o teste dos 108 isolados de $P$. aeruginosa com o padrão ouro, PCR para os genes VIM, SPM e GES, obtivemos uma sensibilidade de 10\%, especificidade de $96 \%$, valor preditivo positivo de $50 \%$ e valor preditivo negativo de $74 \%$. Para os 50 isolados de Acinetobacter spp, quando comparados com o padrão ouro, PCR para os genes IMP, OXA-23 e OXA-143, obtivemos sensibilidade 61\%, especificidade de $33 \%$, valor preditivo positivo de $81 \%$ e um valor preditivo negativo de $16 \%$. 
Tabela 14 - Resultados do teste do Hodge modificado dos 158 isolados de $P$. aeruginosa e Acinetobacter spp.

\begin{tabular}{ccccc}
\hline Microrganismos & $\begin{array}{c}\text { Resultado Teste de } \\
\text { Hodge (no amostras) }\end{array}$ & \multicolumn{3}{c}{ CIM (ug/mL) Imipenem } \\
\cline { 3 - 5 } & Negativo (102) & Intervalo & CIM 50 & CIM 90 \\
\hline \multirow{2}{*}{ P. aeruginosa } & Positivo (6) & $16->256$ & 64 & $>256$ \\
& Negativo (19) & $16-128$ & 64 & 256 \\
\hline \multirow{2}{*}{ Acinetobacter spp } & Positivo (31) & $16-256$ & 64 & 128 \\
& & &
\end{tabular}

\subsection{Avaliação do método de detecção de carbapenemase com ácido borônico}

Foi realizada uma comparação da atividade inibidora da produção de carbapenemases nos 158 isolados de Acinetobacter spp. e $P$. aeruginosa, utilizando diferentes concentrações de ácido 3-aminofenilboronico e ácido fenilboronico nas concentrações $200 \mu \mathrm{g} / \mathrm{mL}, 300 \mu \mathrm{g} / \mathrm{mL}$ e $400 \mu \mathrm{g} / \mathrm{mL}$ de cada ácido por disco. Os inibidores foram combinados com diferentes antimicrobianos, ertapenem, meropenem e imipenem. A leitura foi considerada positiva nos discos contendo o ácido $A F B$ ou $A A B$ que obteve um halo com diâmetro $\geq 5 \mathrm{~mm}$ em relação ao disco sem o ácido.

Este teste foi mais sensível para detectar carbapenemase em isolados de Acinetobater spp quando usado como substrato meropenem e ertapenem (Tabela 15). 
Tabela 15 - Sensibilidade e especificidade (\%) do ácido fenilborônico com o ácido aminofenilborônico dos 158 isolados de Pseudomonas aeruginosa / Acinetobacter spp.

\begin{tabular}{|c|c|c|c|c|c|c|c|c|c|c|c|c|}
\hline \multirow[t]{2}{*}{ Substrato } & \multicolumn{6}{|c|}{ Acido Fenilborônico (AFB) } & \multicolumn{6}{|c|}{ Acido Aminofenilborônico (AAB) } \\
\hline & \multicolumn{12}{|c|}{ Pseudomonas aeruginosa $(\mathrm{n}=108)$} \\
\hline \multirow{2}{*}{ Antimicrobiano } & \multicolumn{2}{|c|}{$200 \mu \mathrm{g} / \mathrm{mL}$} & \multicolumn{2}{|c|}{$300 \mu \mathrm{g} / \mathrm{mL}$} & \multicolumn{2}{|c|}{$400 \mu \mathrm{g} / \mathrm{mL}$} & \multicolumn{2}{|c|}{$200 \mu \mathrm{g} / \mathrm{mL}$} & \multicolumn{2}{|c|}{$300 \mu \mathrm{g} / \mathrm{mL}$} & \multicolumn{2}{|c|}{$400 \mu \mathrm{g} / \mathrm{mL}$} \\
\hline & Sen. $(\%)$ & Esp.(\%) & Sen. $(\%)$ & Esp.(\%) & Sen. $(\%)$ & Esp.(\%) & Sen. (\%) & Esp.(\%) & Sen. (\%) & Esp.(\%) & Sen. $(\%)$ & Esp.(\%) \\
\hline Imipenem & 3,6 & 47,2 & 3,7 & 48,1 & 5,4 & 49,1 & 4,9 & 58,2 & 7,4 & 65,4 & 4,2 & 65,5 \\
\hline Meropenem & 40,0 & 73,5 & 30,7 & 72,6 & 42,8 & 73,2 & 9,1 & 70,1 & 20,0 & 70,9 & 16,6 & 70,8 \\
\hline \multirow[t]{2}{*}{ Ertapenem } & 28,6 & 72,3 & 20,0 & 70,9 & 21,4 & 71,3 & 22,2 & 71,1 & 26,7 & 72,0 & 21,4 & 71,3 \\
\hline & \multicolumn{12}{|c|}{ Acinetobacter spp. $(n=50)$} \\
\hline Imipenem & 66,6 & 17,0 & 87,5 & 19,0 & 83,3 & 18,4 & 0,0 & 18,0 & 0,0 & 18,0 & 0,0 & 0,0 \\
\hline Meropenem & 88,9 & 19,5 & 83,3 & 18,7 & 88,9 & 26,1 & 100,0 & 18,3 & 100,0 & 18,3 & 50,0 & 16,7 \\
\hline Ertapenem & 66,6 & 17,0 & 70,0 & 17,0 & 90,9 & 20,0 & 100,0 & 18,7 & 100,0 & 18,7 & 100,0 & 18,7 \\
\hline
\end{tabular}




\subsection{Hidrólise do Imipenem}

O teste de hidrólise de imipenem foi realizado em algumas amostras que apresentaram positividade em algum teste fenotípico para carbapenemases pesquisadas e em todas as amostras com PCR positivos para um dos genes de carbapenemases estudados.

Foi realizada em 49 isolados de $P$. aeruginosa, destas amostras, 24 $(48,9 \%)$ apresentavam um gene codificador da $\mathrm{M} \beta \mathrm{L}$, tendo queda na absorbância, indicando a hidrólise do antimicrobiano e a inibição posterior dessa atividade com a presença do EDTA. Apenas um isolado com a presença do gene SPM, não apresentou hidrólise do antimicrobiano. Oito amostras de $P$. aeruginosa não apresentaram a hidrólise do antimicrobiano, mas apresentavam algum teste fenotípico positivo para MßL.

Para os Acinetobacter spp. o teste de hidrólise foi realizado em 23 isolados, desses isolados 6 (26\%) apresentaram uma queda na absorbância do imipenem. Três isolados que apresentaram o gene IMP apresentaram hidrólise e a inibição posterior dessa atividade com a presença do EDTA. Apenas dois isolados com a presença do gene IMP, não apresentaram hidrólise. Para os genes das oxacilinases OXA-23 e OXA-143, apenas dois isolados apresentaram hidrólise positiva.

Esse teste apresentou sensibilidade de $100 \%$ e $80 \%$ de especificidade para $P$. aeruginosa e para $A$. baumannii uma sensibilidade de $50 \%$ e especificidade de $88 \%$ quando comparados com o padrão-ouro PCR para os genes codificadores de M $\beta L$. E quando comparados os $A$. baumannii com os genes codificadores das oxacilinases, o teste apresentou sensibilidade de 13,3\% e especificidade de $50 \%$. 
Tabela 16 - Comparação do teste de hidrólise com outras técnicas fenotípicas para detecção de carbapenemase dos 49 isolados de $P$. aeruginosa

\begin{tabular}{|c|c|c|c|c|c|}
\hline № isolado & Hidrólise & Hodge & Teste Fenotípico & $\begin{array}{c}\text { Etest }^{\circledR} \\
\text { M } \beta L\end{array}$ & $\begin{array}{c}\text { Carbapenemase } \\
\text { PCR }\end{array}$ \\
\hline $3 / 09$ & Positiva & Negativo & PCBE/PIE/IMPE & Positivo & VIM \\
\hline $5 / 09$ & Positiva & Negativo & PCBE/PIE/ IMPE & Positivo & VIM \\
\hline 23 & Positiva & Positivo & PICBE & Positivo & VIM \\
\hline 81 & Positiva & Negativo & PIB/ IMPE & Positivo & VIM \\
\hline $1 / 09$ & Positiva & Negativo & PCE/PIE & Positivo & SPM \\
\hline $1 / 07$ & Positiva & Negativo & PCE/PIE/IMPE & Positivo & SPM \\
\hline $3 / 07$ & Positiva & Negativo & PCE/PIE/IMPE & Positivo & SPM \\
\hline $6 / 07$ & Positiva & Negativo & PCE/IMPE & Positivo & SPM \\
\hline 1 & Positiva & Positivo & IMPE & Positivo & SPM \\
\hline $9 / 09$ & Positiva & Negativo & PCE/PIE/IMPE & Positivo & SPM \\
\hline $8 / 07$ & Positiva & Negativo & Negativo & Positivo & SPM \\
\hline $9 / 07$ & Positiva & Negativo & PCE/PIE/IMPE & Positivo & SPM \\
\hline $12 / 09$ & Positiva & Negativo & PCE/IMPE & Positivo & SPM \\
\hline $12 / 07$ & Positiva & Negativo & PCE/IMPE & Positivo & SPM \\
\hline 2 & Positiva & Negativo & IMPE & Positivo & SPM \\
\hline 17 & Negativa & Negativo & IMPE & Positivo & SPM \\
\hline 45 & Positiva & Negativo & IMPE & Positivo & SPM \\
\hline 57 & Positiva & Negativo & IMPE & Positivo & SPM \\
\hline 62 & Positiva & Negativo & IMPE & Positivo & SPM \\
\hline 74 & Positiva & Negativo & Negativo & Positivo & SPM \\
\hline 85 & Positiva & Negativo & PCB/ IMPE & Positivo & SPM \\
\hline 86 & Positiva & Negativo & IMPE & Positivo & SPM \\
\hline 105 & Positiva & Negativo & IMPE & Positivo & SPM \\
\hline 107 & Positiva & Negativo & IMPE & Positivo & SPM \\
\hline 109 & Positiva & Negativo & PIE/ IMPE & Positivo & SPM \\
\hline 28 & Negativa & Negativo & PCBE & Negativo & GES \\
\hline 29 & Negativa & Negativo & Negativo & Positivo & GES \\
\hline 30 & Negativa & Positivo & Negativo & Positivo & GES \\
\hline 82 & Negativa & Negativo & IMPE & Positivo & GES \\
\hline 4 & Negativa & Negativo & PIB & Negativo & - \\
\hline 6 & Negativa & Negativo & Negativo & Negativo & - \\
\hline 8 & Negativa & Negativo & PCBE & Positivo & - \\
\hline 22 & Negativa & Negativo & Negativo & Positivo & - \\
\hline 27 & Negativa & Negativo & Negativo & Negativo & - \\
\hline 39 & Negativa & Negativo & Negativo & Negativo & - \\
\hline 40 & Negativa & Negativo & Negativo & Negativo & - \\
\hline 41 & Negativa & Negativo & Negativo & Positivo & - \\
\hline 42 & Negativa & Negativo & PCBE & Negativo & - \\
\hline 43 & Negativa & Negativo & Negativo & Negativo & - \\
\hline 44 & Negativa & Negativo & PCB & Positivo & - \\
\hline 63 & Negativa & Negativo & Negativo & Negativo & - \\
\hline 64 & Negativa & Negativo & Negativo & Negativo & - \\
\hline 67 & Negativa & Negativo & Negativo & Negativo & - \\
\hline 68 & Negativa & Negativo & PCE & Positivo & - \\
\hline 79 & Negativa & Negativo & PCBE/ IMPE & Positivo & - \\
\hline 84 & Negativa & Negativo & Negativo & Negativo & - \\
\hline 87 & Negativa & Negativo & PIE/IMPE & Negativo & - \\
\hline 98 & Negativa & Negativo & IMPE & Negativo & - \\
\hline 106 & Negativa & Negativo & Negativo & Negativo & - \\
\hline
\end{tabular}

NOTA: IMPE: diferença maior que $8 \mathrm{~mm}$ entre os diâmetros do IMI e I+E, P: positivo, C: ceftazitima, E: EDTA, B: ABM (Ácido $\beta$-mercaptoetanol), I: imipenem 
Tabela 17 - Comparação do teste de hidrólise com outras técnicas fenotípicas para detecção de carbapenemases dos 23 isolados de Acinetobacter spp.

\begin{tabular}{cccccc}
\hline No isolado & Hodge & Hidrólise & Teste Fenotípico & $\begin{array}{c}\text { Etest } \\
\text { M } \beta \text { L }\end{array}$ & $\begin{array}{c}\text { Carbanemase } \\
\text { PCR }\end{array}$ \\
\hline 6 & Positivo & Positiva & PIBE/PCB & Positivo & $51 /$ IMP \\
7 & Positivo & Positiva & PIB & Positivo & $51 /$ IMP \\
13 & Negativo & Negativa & Negativo & Negativo & 51 \\
23 & Positivo & Negativa & Negativo & Positivo & $51 / 143$ \\
25 & Positivo & Negativa & PIB/IMPE & Positivo & 51 \\
30 & Positivo & Negativa & Negativo & Positivo & $51 / 143 /$ IMP \\
35 & Negativo & Negativa & Negativo & Positivo & $51 / 143$ \\
38 & Positivo & Negativa & IMPE & Positivo & $51 / 143$ \\
43 & Positivo & Negativa & PIB/PCB/IMPE & Positivo & $51 /$ MP \\
44 & Positivo & Positiva & PIB/PCB/IMPE & Positivo & 51 \\
52 & Positivo & Positiva & PIB/IMPE & Positivo & $143 / / M P$ \\
55 & Positivo & Positiva & PIB/IMPE & Positivo & 51 \\
56 & Negativo & Negativa & PIB & Positivo & $51 / 143$ \\
57 & Negativo & Negativa & Negativo & Positivo & $51 / 143$ \\
61 & Positivo & Negativa & IMPE & Negativo & $23 / 51 / 143$ \\
65 & Positivo & Negativa & Negativo & Negativo & $23 / 51 / 143$ \\
69 & Positivo & Negativa & PIB/PCE & Positivo & $23 / 51 / 143$ \\
70 & Positivo & Negativa & PCE & Positivo & $23 / 51 / 143$ \\
71 & Positivo & Negativa & PCE & Positivo & $23 / 51 / 143$ \\
73 & Negativo & Negativa & Negativo & Positivo & $23 / 51 / 143$ \\
75 & Negativo & Negativa & PIB & Positivo & $23 / 51 / 143$ \\
76 & Positivo & Negativa & PCE & Positivo & $23 / 51 / 143$ \\
77 & Positivo & Positiva & PIB & Positivo & $23 / 51$ \\
\hline
\end{tabular}

Nota: IMPE: diferença maior que $8 \mathrm{~mm}$ entre os diâmetros do IMI e I+E, P: positivo, C: ceftazitima, E: EDTA, B: ABM (Ácido $\beta$-mercaptoetanol), I: imipenem 


\section{5 . DISCUSSÃO}

O presente estudo avaliou métodos fenotípicos e genotípicos para identificação de carbapenemases em amostras de Acinetobacter spp e $P$. aeruginosa. A detecção rápida e confiável de agentes multi-resistentes e de genes codificadores de carbapenemases, um dos principais mecanismo de resistência aos carbapênemicos descrito em isolados de Acinetobacter spp e $P$. aeruginosa, pode ser útil para implementar medidas de controle e prevenção da disseminação desse mecanismo de resistência (Kitao et al, 2011 e Khosravi, 2012).

Como descrito previamente, Acinetobacter spp. é um importante agente de infecção nosocomial, em particular nos hospitais brasileiros. $O$ grupo $A$. calcoaceticus - A. baumanni é o de maior importância clínica, as espécies desse gênero podem variar sua sensibilidade aos antimicrobianos. Por isso, faz se necessário a identificação ao nível de espécies (Peleg et al.,2008). O presente estudo identificou as amostras pelo sistema fenotípico miniaturizado API20NE. Esse sistema identificou os isolados como grupo $A$. calcoaceticus - $A$. baumannii, e não conseguiu diferenciar as espécies. A diferenciação das espécies foi feita por meio da técnica de PCR do gene bla oxa-51-like, que é intrínseco da espécie $A$. baumannii, já demonstrado por Héritier e colaboradores em 2005, como um marcador para essa espécie. A única espécie não identificada como $A$. baumannii, após a análise do sequenciamento do gene codificador do RNA $16 \mathrm{~S}$ foi designada como A. calcoaceticus.

A amostras de $P$. aeruginosa do presente estudo foram identificadas pelo sistema automatizado VITEK $^{\circledR}$ (BioMérieux, EUA) com o cartão GN e a certificação da pureza e a confirmação realizada por meio de provas bioquímicas manuais, tais como oxidação da glicose em meio basal de Moeller, crescimento a $42^{\circ} \mathrm{C}$, produção de oxidase, crescimento em ágar cetrimida, descarboxilação da arginina e utilização de citrato. 
O conhecimento de dados brasileiros de resistência bacteriana é de suma importância para delinear medidas de prevenção regional e nacional e estratégias de tratamento das infecções hospitalares por agente multirresistentes. O presente estudo contribuiu para ampliar o conhecimento sobre a frequência e a distribuição de genes codificadores de carbapenemase e a clonalidade de amostras de Acinetobacter spp e $P$. aeruginosa isoladas no HC-FMUSP. SPM foi a carbapenemase mais frequente nas amostras de $P$. aeruginosa e Oxa-23 e Oxa-143 nas amostras de Acinetobacter spp. As oxacilinases possuem um menor poder de hidrólise dos carbapenêmicos quando comparadas com as MßLs, essas enzimas são as carbapenemases mais descritas em Acinetobacter spp até o momento (Boo e Crowley, 2009).

No presente estudo dos 108 isolados $P$. aeruginosa, apenas 25 isolados apresentaram enzimas do grupo $\mathrm{M} \beta \mathrm{L}$, sendo a maioria gene blasPM-1 (21 isolados) e 5 isolados positivos para o gene blaviM-2. E para os 50 isolados de $A$. baumannii encontramos 5 isolados foram positivos para gene bla|MP-1.

Das amostras de $P$. aeruginosa, $27 / 108$ isolados pertenciam ao mesmo clone denominado de padrão A. Nenhuma dessas amostras, entretanto, foi positiva para os genes de carbapenemase pesquisados. Por outro lado, nove dos 21 isolados positivos para o gene codificador de SPM apresentaram a mesma clonalidade, esses isolados foram identificados em dois surtos que ocorreram na unidade de transplante de medula nos anos de 2007 e 2009.

A prevalência de $M \beta L$ em $P$. aeruginosa em estudos brasileiros varia de $7,5 \%$ a $44 \%$ em diferentes regiões geográficas (Franco et al., 2010). A enzima SPM-1 descrita por Toleman e colaboradores (2002) é a mais frequente em isolados de $P$. aeruginosa resistente aos carbapenêmicos descritos no Brasil. Outras MßLs identificadas no Brasil são IMP e VIM. (Neves et al; 2011, Camargo et al; 2011, Marra et al.; 2006). No HC-FMUSP, um surto de 13 isolados de $P$. aeruginosa produtoras do gene codificador de $M \beta L$ foi descrito por Paez et al. (2011). Esse surto ocorreu na unidade de transplante de medula óssea do HC-FMUSP, foram identificadas SPM e VIM no mesmo surto, onze isolados continham o gene codificador de SPM e dois de VIM. Esse achado foi 
interessante por demonstra à coexistência de diferentes genes codificadores de carbapenemase no mesmo surto.

Segundo Cornaglia (2011), no Brasil além da SPM-1 ser a principal $M \beta L$, IMP-1 foi descrita em enterobactérias e Gram-negativos não fermentadores e também IMP-16 e VIM-2 em isolados de $P$. aeruginosa. Até o momento, entretanto, não há relato de SPM-1 fora do Brasil, seu país de origem.

Dos isolados de Acinetobacter spp. avaliados no presente estudo, sete pertenciam ao mesmo clone, sendo que destes, seis apresentaram o gene bla oxa-51/ oxa-23/ oxa-143 e apenas um isolado apresentou o gene bla oxa-51/ oxa-23.

A alta resistência aos carbapenêmicos encontrada no nosso estudo, com CIM elevadas, além de estar relacionada à produção de carbapemases, é provavelmente decorrente da associação de múltiplos mecanismos de resistência, como perda de porina específica e expressão da bomba efluxo (Camargo et al.; 2011,Livermore, et al; 2002). O presente estudo não avaliou outros mecanismos de resistência.

Um teste fenotípico rápido e de fácil execução para triagem de carbapemenases é importante para delinear medidas de controle de infecções da transmissão desse mecanismo de resistência. Vários estudos avaliaram diferentes substratos e inibidores de $\mathrm{M} \beta \mathrm{L}$ associados à pesquisa da produção $M \beta L$ nas bactérias, mas nenhuma padronização para detecção de $M \beta L$ é recomendada pelo CLSI (Camargo, 2011). A detecção dos genes de carbapenemases por métodos moleculares é considerada o padrão-ouro, mas está disponível em poucos laboratórios de referência e, portanto os testes fenotípicos ainda são os mais utilizados na rotina (Birgy, 2012).

O critério de seleção para a confirmação da presença de genes codificadores de $\mathrm{M} \beta \mathrm{L}$ é a sensibilidade reduzida ou resistência a carbapenêmicos e / ou ceftazidima em amostras de $P$. aeruginosa e Acinetobacter spp. Atualmente, o método fenotípico comercialmente disponivel para detectar $M \beta L$ e um dos mais usados é o Etest ${ }^{\circledR}$. No entanto, devido ao 
elevado custo, muitos laboratórios de microbiologia clínica utilizam métodos alternativos, tais como o DDST e o CD / teste de disco potenciação (DPT). Embora o DDST e o ensaio DPT sejam simples de executar e mais baratos do que $\circ$ Etest $^{\circledR}$ eles têm mostrado resultados discordantes, dependendo da metodologia empregada, substratos de $\beta$-lactâmicos, inibidores de $M \beta L$ e do gênero da bactéria avaliada (Buchunde, 2012). Os inibidores de $M \beta L$ utilizados nesses métodos incluem o metal quelante EDTA, compostos de tiol (ácido mercaptopropiónico ou ácido mercaptoacético de sódio) e ácido dipicolínico (Birgy, 2012).

Vários testes fenotípicos foram utilizados neste estudo para a detecção de carbapenemases. Para a detecção das $\mathrm{M} \beta \mathrm{L}$ foram utilizadas três diferentes metodologias: Etest ${ }^{\circledR}$ para $\mathrm{M} \beta L$, DDST e CD. Na nossa casuística, quando comparado com a metodologia padrão-ouro, a PCR, o Etest ${ }^{\circledR}$ para M $\mathrm{ML}$ apresentou sensibilidade de $100 \%$ e especificidade de $19,3 \%$ para $P$. aeruginosa e para os Acinetobacter spp sensibilidade de 100\% e especificidade de $8,9 \%$. Essa metodologia é simples e prática de executar, porém apresenta um custo mais elevado por ser disponível comercialmente.

As oxacilinases encontradas nos 50 isolados de $A$. baumannii no presente estudo foram OXA-23 (18\%), OXA-51 (98\%) e a OXA-143 (76\%). Segundo Yang e colaboradores (2010), mesmo tendo um baixo poder de hidrólise quando comparadas as $\mathrm{M} \beta \mathrm{L}$, as oxacilinases são as enzimas que mais frequentemente conferem resistência aos carbapenêmicos nos Acinetobacter spp. No presente estudo, o teste fenotípico que identificou com maior frequência a presença de oxacilinase foi DDST com disco imipenem, obtendo sensibilidade de $100 \%$ e especificidade de $21 \%$. Apesar de uma ótima sensibilidade este teste foi pouco específico.

O Etest ${ }^{\circledR}$ para $M \beta L$ apresentou baixa especificidade para triar $M \beta L$ em amostras de Acinetobacter spp. Segal e colaboradores (2005) relacionam essa limitação da detecção das $\mathrm{M} \beta L$ s pela metodologia do Etest ${ }^{\circledR}$ a presença das enzimas OXA-23. Entretanto, neste estudo, a incapacidade da detecção de MßL em amostras de Acinetobacter spp. esteve relacionada não só com a presença 
das enzimas OXA-23, mas também com a enzima intrínseca OXA-51. Dos 23 isolados que realizamos o teste de hidrólise, apenas cinco hidrolisaram carbapenêmicos. Quando comparamos 0 Etest ${ }^{\circledR}$ constatamos que esse teste não diferencia $\mathrm{M} \beta \mathrm{L}$ de outras carbapenemases, pois obtivemos uma sensibilidade de $82 \%$ e especificidade de $25 \%$ para Acinetobacter spp.

Em um estudo realizado por Arakawa e colaboradores (2000), o agente quelante MPA (2-mercaptopropiônico), apresentou sensibilidade de 100\% para triagem de $\mathrm{M} \beta \mathrm{L}$ quando utilizado como substrato ceftazidima, quando comparado com outros agentes quelantes. $O$ nosso estudo comparou as metodologias DDST com dois inibidores EDTA e ABM ( $\beta$-mercaptoetanol) com dois substratos diferentes IMI e CAZ. Nós obtivemos melhores resultados para $P$. aeruginosa com o substrato de CAZ com inibidor EDTA, que apresentou sensibilidade de $48 \%$ e especificidade $93 \%$. Para Acinetobacter spp o melhor substrato foi o IMI com inibidor ABM, que apresentou sensibilidade de $100 \% \mathrm{e}$ especificidade de $71 \%$. E quando comparamos a diferença de halo $\geq 8 \mathrm{~mm}$, do imipenem sozinho e com imipenem associado ao EDTA obtivemos melhor resultado para os Acinetobacter spp, sensibilidade de $100 \%$ e especificidade de $42 \%$.

Estudos brasileiros evidenciaram resultados discordantes dos métodos fenotípicos para triagem de carbapenemases em Gram- negativos e nãofermentadores fermentadores. Picão e colaboradores (2008) avaliaram também a metodologia DDST, e obtiveram os melhores resultados para detecção de MBL com o quelante MPA (ácido mercaptopropiônico), para os isolados de $P$. aeruginosa e Acinetobacter spp. Entretanto a melhor distância avaliada entre os discos foi de $2,0 \mathrm{~cm}$ tendo uma sensibilidade e especificidade de $100 \%$, usando IMI como substrato para Acinetobacter spp e a CAZ para $P$. aeruginosa. Já Camargo e colaboradores (2011), também obtiveram melhores resultados como substrato CAZ, associado ao MPA, para $P$. aeruginosa.

Em outro estudo realizado por Lee e colaboradores (2003), o ácido mercaptoacético foi o que apresentou sensibilidade de $100 \%$ na detecção de isolados de Acinetobacter spp produtores de MßLs, porém esse quelante não foi 
um bom marcador para detectar a presença de carbapenemase em isolados de Pseudomonas spp..

No presente estudo, como já citado previamente, vários testes foram realizados para triagem de carbapenemases, entre eles o teste de Hodge modificado. O teste de Hodge modificado foi avaliado para triagm de MßLs, oxacilinases, KPC e GES das 158 amostras de P. aeruginosa e Acinetobacter spp. Este teste não apresentou uma boa sensibilidade no geral quando comparamos as diversas carbapenemases encontradas, obtivemos para $P$. aeruginosa sensibilidade de $10 \%$ e especificidade de $96 \%$ e para Acinetobacter spp. sensibilidade de $61 \%$ e especificidade de $33 \%$. Quando analisamos o Hodge somente com os isolados positivo para $\mathrm{M} \beta \mathrm{L}$, obtivemos um melhor resultado para Acinetobacter spp., sensibilidade de $100 \%$ e especificade de $42 \%$ do quee para $P$. aeruginosa, sensibilidade baixa de $8 \%$ e especificidade de $95 \%$.

O teste de Hodge modificado também vem sendo usado como triagem para detecção de amostras suspeitas de NDM-1, embora seu diagnóstico definitivo seja pelo PCR (Amjad A. et al., 2011). Girlich et al., 2012, modificaram o teste de Hodge a fim de melhorar os limites de detecção das cepas produtoras de NDM e outras MßLs, adicionando sulfato de zinco em ágar Müeller Hinton em diversas concentrações, para detecção de IMP e VIM em $P$. aeruginosa e Acinetobacter spp. A sensibilidade aumentou de $77,4 \%$ para $94 \%$, esse estudo mostrou que essa técnica é mais sensível após a adição de zinco no meio, mas possui uma limitação quando ao desempenho clínico porque permanece com especificidade de $38,9 \%$ com ou sem zinco. Uma das limitações do nosso estudo é que não adicionamos zinco na realização do teste de Hodge, o que pode explicar o nosso resultado pífio.

Nossos resultados corroboram os dados da literatura que mostram que a sensibilidade e a especificidade dos testes fenotípicos para triagem de carbapenemase variam de acordo com os agentes estudados é que não existe até o momento um método considerado ótimo. 
Quando utilizada a hidrólise de imipenem comparada a PCR, essa metodologia apresentou sensibilidade de $100 \%$ e especificidade de $80 \%$ para $P$. aeruginosa, e sensibilidade de $50 \%$ e especificidade de $88 \%$ para os $A$. baumannii. Dos 49 isolados $P$. aeruginosa analisados, 24 apresentaram hidrólise positiva, nenhuma GES foi positiva e apenas uma SPM foi negativa. Dos 23 isolados de Acinetobacter spp que realizamos o teste de hidrólise, somente seis isolados hidrolizaram imipenem. Entre estes seis isolados, dois continham somente oxa-51, dois continham-oxa-51 e IMP, um continha oxa-143 e IMP e um continha oxa-51 e oxa-23. Cinco isolados de Acinetobacter spp. com genes positivos para IMI foram positivos para Etest ${ }^{\circledR}$ para $M \beta L$, no entanto eles continham oxa-51 e oxa-143, apenas dois isolados positivos para IMP não apresentaram hidrólise. Os isolados continham duas ou mais carbapenemases, o que dificultou a interpretação dos resultados.

Esses achados são interessantes, pois a maioria dos estudos utiliza a detecção do gene de carbapenemase como o padrão-ouro para avaliação dos testes fenotípicos, e não a hidrólise do carbapenêmico.

Portanto, não existe um único teste fenotípico que consiga identificar carbapenemases em amostras de Acinetobacter spp. e $P$. aeruginosa, que possa ser imediatamente implantado em laboratório de microbiologia de rotina. Nossos dados confirmaram que a performance do teste varia de acordo com as carbapenemases presentes em cada serviço.

Outra grande dificuldade para implantação de um teste fenotípico para triagem de carbapenemase na rotina de um laboratório de microbiologia, é que os testes são caseiros, o que dificulta a padronização e exequibilidade dos mesmos complicada. O teste fenotípico disponível comercialmente, Etest ${ }^{\circledR}$ com EDTA é caro para a realidade brasileira e é muito sensível e pouco especifico. Por sua vez, a PCR convencional, considerada o padrão-ouro, é rápida e de fácil realização, entretanto, precisa de uma estrutura laboratorial que a maioria dos laboratórios de microbiologia não têm no Brasil. Vale ressaltar que a detecção da presença de um gene codificador de carbapenemase não necessariamente 
significa que o gene está expresso, como demostrado pelos resultados da hidrólise de imipenem do presente estudo.

Novas metodologias moleculares que detectem o agente, o gene de resistência e a expressão dos mesmos como "microarray" devem ser no futuro comercializadas e utilizadas na rotina do controle e disseminação da resistência (Lascols et al 2012; Cuzon et al 2012). Essa nova tecnologia pode detectar um número quase ilimitado de genes dentro de uma única reação, e foi recentemente aplicadas para detectar genes de carbapenemases. Cuzon e colaboradores (2012) desenvolveram um painel de "microarray" para detectar carbapenemases clinicamente relevantes como KPC, OXA-48, VIM, IMP e NDM. Os autores avaliaram 89 isolados de gram-negativos multirresistentes, o teste obteve $100 \%$ sensibilidade e especificidade. Essas novas técnicas serão incorporadas no futuro na rotina dos hospitais e terão provavelmente impacto no custo e morbidade das infecções por bactérias multirresistentes.

Portanto, o presente estudo mostrou que não existe um teste fenotípico único que possa ser utilizado no laboratório de rotina para triagem de todas as carbapenemases, e que os resultados dos testes fenotípicos variam de acordo com a prevalência dos genes codificadores de carbapenemases e com a patógeno a ser avaliado. 


\section{CONCLUSÕES}

* SPM-1 e VIM-2 foram as MßL identificadas em $P$. aeruginosa e IMP-1 em A. baumannii.

* As Oxa-23 e Oxa-143 foram as oxacillinases identificadas nas amostras de Acinetobacter spp.

* O gene GES-5 foi identificado em quatro isolados de $P$. aeruginosa e nenhum gene codificador de KPC nem de NDM foi encontrado nas amostras de $P$. aeruginosa e Acinetobacter spp.

* Os isolados de $P$. aeruginosa foram agrupados em nove clusters pela tipagem molecular, sendo o cluster A o predominante ( $25 \%$ isolados).

* Nove dos isolados de P. aeruginosa SPM positivos pertenciam a um mesmo clone, sendo que essas amostras faziam parte de um surto que ocorreu no HC-FMUSP nos anos de 2007 e 2009.

* Os isolados de Acinetobacter spp. foram agrupados em 10 clusters, sendo o cluster A o predominante (62\% isolados).

* As amostras de Acinetobacter spp. positivas para os genes codificadores de Oxa-23 e Oxa-143 foram policlonais diferente das amostras identificadas com o gene IMP-1 que pertenciam a um único clone.

* Etest-M $\quad$ L foi o teste mais sensível e apresentou sensibilidade de $100 \%$ para triagem de M $\mathrm{BL}$ em $P$. aeruginosa e Acinetobacter spp e de $75 \%$ para GES, entretanto, não conseguiu diferenciar oxacillinase de M $\mathrm{ML}$ em Acinetobacter spp e apresentou baixa especificidade que variou de 8 a $19 \%$.

* A melhor metodologia fenotípica para detecção de M $\beta L$ nos isolados de $P$. aeruginosa, foi a diferença de halo $\geq 8 \mathrm{~mm}$ do IMI com IMI impregnado com EDTA, que apresentou sensibilidade de $72 \%$ e especificidade de $73 \%$. 
* Para os isolados de Acinetobacter spp a melhor medotologia fenotípica para detecção de $M \beta L$ foi a aproximação de disco de imipenem com um disco de ABM, que apresentou sensibilidade de $100 \%$ e especificidade de $71 \%$.

* O teste de Hodge apresentou baixa sensibilidade para identificar carbapenemases, sendo superior na avaliação das amostras de Acinetobacter spp (S: $61 \%$ e E: 33\%), do que nas de amostras de $P$. aeruginosa (S: $10 \%$ e E: 96\%). 


\section{REFERÊNCIAS BIBLIOGRÁFICAS}

Anderson, K. F.; Lonsway, R. D.; Rasheed, K. J.; Biddle, J.; Jensen, B.; Mcdougal, L. K. et al. Evaluation of methods 193 Modified Hod g e test for detection of carbapenemase to identify the Klebsiella pneumoniae carbapenemase in Enterobacteriaceae. J Clin Microbiol, 2007, 45: 2723 -2725.

Ambler, R P. The structure of $\beta$-lactamases. Philosophical Transactions of the Royal Society, B: Biol. Sciences, 1980; (289) 321-31.

Amjad, A*.; Mirza,IA.; Abbasi, AS.; Farwa, U.; Malik, N.;Zia, F. Modified Hodge test: A simple and effective test for detection of carbapenemase production. Iranian J. Microbiol. 2011, 4: 189-19.

Arakawa, Y. et al. Convenient test for screening metallo- $\beta$-lactamase: producing gram-negative bacteria by using thiol compounds. J. Clin. Microbiol, 2000, 38:40-3.

Bellido, F.; Veuthey, C.; Blaser, J. Novel resistance to imipenem associated with an altered PBP-4 in a Pseudomonas aeruginosa clinical isolate. J. Antimicrob Chemother, 1990, (25): 57-68.

Berçot, B.; Poirel, L.; Dortet, L.; Nordmann, P. In vitro evaluation of antibiotic synergy for NDM-1-producing Enterobacteriaceae. J. Antimicrob. Chemother, 2011, Aug; 1-3.

Birgy, A.; Bidet, P.; Genel, N.; Doit, C.; Decré, D.; Arlet, G.; Bingen, E. Phenotypic screening of carbapenemases and associated $\beta$-lactamases in carbapenem- resistant Enterobacteriaceae. J. Clin. Microbiol. 2012, 1295-1302.

Boo, T.W. \&\& Crowley, B. Detection of bla-oxa58 and bla-oxa-23-like in carbapenemsuscetible Acinetobacter clinical isolates: should we be concerned? J. Medic. Microbiol. 2009. 
Bradford, P. A.; Bratu, S.; Urban, C.; Visalli, M.; Mariano, N.; Landman, J.; Rahal, J.; Brooks, S.; Cebular, S.; Quale, J. Emergence of carbapenem-resistant Klebsiella species possessing the class A carbapenemhydrolyzing KPC-2 and inhibitor TEM-30 $\beta$-lactamases in New York City. Clin. Infect. Dis. 2004, 39: 5560.

Buchunde, S.; Mendiratta, DK.; Deotale, V.; Narang, P. Comparison of disc and MIC reduction methods with polymerase chain for the detection of metallo- $\beta$ lactamase in Pseudomonas aeruginosa. Indian J. Med. Microbiol. 2012, 30:170-174.

Buscher, K. H.; Cullmann, W.; Dick, W.; Opferkuch, W. Imipenem resistance in Pseudomonas aeruginosa resulting from diminished expression of an outer membrane protein. Antimicrob. Agents Chemother, 1987 May, 31(5):703-8.

Bush, K.; Jacoby, G. A.; Updated Functional Classification of $\beta$-Lactamases. Antimicrobial Agents and Chemotherapy. Mar. 2010, p. 969-976

Bush, K.; Jacoby, G. A.; Medeiros, A. A. A functional classification sheme for $\beta$ lactamases and its correlation with molecular structure Antimicrob. Agents Chemother, 1995, (39): 1211-33.

Camargo, CH.; Nascimento, AB.; Mondelli, AL.; Montelli, AC.; SADATSUNE, T. Detection of SPM and IMP metallo- $\beta$-lactamases in clinical specimens of Pseudomonas aeruginosa from a Brazilian public tertiary hospital. Braz. J. Infect. Dis. 2011; 15 (5): 478-481.

Castanheira, M. et al. Emergence of the extended-spectrum beta-lactamase GES-1 in a Pseudomonas aeruginosa strain from Brazil: report from the SENTRY antimicrobial surveillance program. Ant. Agents Chemother, 2004 Jun, 48(6):2344-5. 
Chen, Y.; Zhou, Z.; Jiang, Y.; YU, Y. Emergence of NDM-1-producing Acinetobacter baumannii in China. J Antimicrob Chemother, 2011; 66: 12551259.

Cornaglia, G.; Giamarellou, H.; Rossolini, G. Metallo- $\beta$-lactamases: a last frontier for $\beta$-lactams? Infec. Lancet, 2011

Coyne, S.; Courvalin, P. Efflux-Mediated Antibiotic Resistance in Acinetobacter spp. Antimicrob. Agents Chemother, Mar. 2011, p. 947-953.

Cuzon, G.; Naas, T.; Bogaerts, P.; Glupczynski , Y.; Nordmann, P. Evaluation of a DNA microarray for the rapid detection of extended-spectrum $\beta$-lactamases (TEM, SHV and CTX-M), plasmid-mediated cephalosporinases (CMY-2-like, DHA, FOX, ACC-1, ACT/MIR and CMY-1-like/MOX) and carbapenemases (KPC, OXA-48, VIM, IMP and NDM). J Antimicrob Chemother, 2012 Aug, 67(8):18659.

DA Fonseca, E. L.; Vieira, V. V.; Cipriano, R.; Vicente, A. C. Emergence of blaGES-5 in clinical colistin-only-sensitive (COS) Pseudomonas aeruginosa strain in Brazil. J Antimicrob Chemother, 2007 Mar, 59(3):576-7.

Del Mar Toma M.; Cartelle, M.; Pertega, S. et. al. Hospital outbreak caused by a carbapenem-resistant strain of Acinetobacter baumannii: patient prognosis and risk-factors for colonisation and infection. Clinical Microbiology and Infection, v.11, n.7, p. 540-546, 2005.

Diekema, D. J.; Pfaller, M. A.; Jones, R. N.; Doern, G. V.; Winokur, P. L.; Gales, A. C.; Sader, H. S.; Kugler, K.; Beach, M. Survey of bloodstream infections due to gram-negative bacilli: frequency of occurrence and antimicrobial susceptibility of isolates collected in the United States, Canada, and Latin America for the SENTRY Antimicrobial Surveillance Program, 1997. Clin. Infect. Dis, 1999 Sep, 29(3):595-607. 
Doi, Y.; Potoski, B. et al. Simple Disk-Based Method for Detection of Klebsiella penumoniae Carbapenemase- Type $\beta$ - Lactamase by Use of a Boronic Acid Compound. J. Clin. Microbiol, 2008, 46: 4083-86.

Ellington, M.; Kistler, J. et al. Multiplex PCR for rapid detection of genes encoding acquired metallo- $\beta$-lactamases. J. Antimicrob. Chemother, 2007, 59: 321-322.

Feizabadi M, M.; Fathollahzadeh, B.; Taherikalani, M.; Rasoolinejad, M.; Sadeghifard, N.; Aligholi, M.; Soroush, S.; MOHAMMADI-YEGANE, S. Antimicrobial susceptibility patterns and distribution of blaOXA genes among Acinetobacter spp. Isolated from patients at Tehran hospitals. J Infect Dis, 2008 Jul, 61(4):274-8.

Fernandez-Cuenca, F.; Martinez-Martinez, L.; Conejo, M. C.; Ayala, J. A.; Perea, E. J.; Pascual, A. Relationship between beta-lactamase production, outer membrane protein and penicillin-binding protein profiles on the activity of carbapenems against clinical isolates of Acinetobacter baumannii. J. Antimicrob. Chemother, 2003 Mar, 51(3):565-74.

Flaherby, J. P.; Weinstein, R. A. Nosocomial Infections caused by antibioticresistant organisms in the intensive-care unit. Infect Control Hosp Epidemiol, 1996, 17: 236-248.

Franco, M.; Caiaffa, H. et al. Metallo-beta-lactamases among imipenem-resistant Pseudomonas aeruginosa in a brazilian university hospital. Clinical Science, 2010, 65(9):825-829.

Gales, A. C.; Castanheira, M.; Jones, R. N.; Sader, H. S. Antimicrobial resistance among Gram-negative bacilli isolated from LatinAmerica: results from SENTRY Antimicrobial Surveillance Program (LatinAmerica, 2008-2010). Diagnostic Microbiol. and Infec. Dis, 2012, 73 354-360. 
Gales, A. C.; Jones, R.; Forward, K. R.; Linares, J.; Sader, H.; Verhoef, J. J. Emerging importance of multidrug-resitance Acinetobacter species and Stenotrophomonas maltophilia as pathogens in seriously ill patients: geographic patterns, epidemiological features, and trends in the SENTRY Antimicrobial Surveillance Program (1997-1999). Clin. Infec. Diseases, 2001, 15 (2): 104-113.

Gales, A.; Jones, R.; Sader, H. Contemporary activity of colistin and polymyxin B against a worldwide collection of Gram-negative pathogens: results from the SENTRY Antimicrobial Surveillance Program (2006-09). J. Antimicrob. Chemother, 2011 June, 66: 2070-74.

Gales, A. C.; Tognim, M. C.; Reis, A. O.; JONES, R. N.; SADER, H. S. Emergence of an IMP-like metallo-enzyme in an Acinetobacter baumannii clinical strain from a Brazilian teaching hospital. Diagn Microbiol Infect Dis, 2003 Jan, 45(1):77-9.

Gales, A. C.; Menezes, L. C.; Silbert, S.; Sader, H. S. Dissemination in distinct Brasilian regions of an epidemic carbapenem-resistant Pseudomonas aeruginosa producing SPM metallo- $\beta$-lactamase. J. Antimicrob. Chemotherapy, 2003, 52: 699-702.

Gehrlein, M.; Leying, H.; Cullmann, W.; Wendt, S.; Opferkuch, W. Imipenem resistance in Acinetobacter baumanii is due to altered penicillin-binding proteins. Chemotherapy, 1991; 37 (6): 405-12.

Giamarellou, H.; Antoniadou, A.; Kanellakopoulou, K. Acinetobacter baumannii: a universal threat to public health? Intern J Antimicrob Agents, 2008, 32(2): 10619.

Girão, E.; Levin, A. et al. Trends and outcome of 1121 nosocomial bloodstream infections in intensive care units in a Brazilian hospital, 1999-2003. Inter. J. Infec. Dis, 2008, 12 144-146. 
Girlich, D.; Poirel, L.; Nordmann, P. Value of the Modified Hodge Test for Detection of Emerging Carbapenemases in Enterobacteriaceae. J. Clin. Microbiol., 2012, 50 (2) 477-79.

Heritier, C.; Dubouix, A.; Poirel, L.; Marty, N.; Nordmann, P. A nosocomial outbreak of Acinetobacter baumannii isolates expressing the carbapenemhydrolysing oxacilinase OXA-58. J. Antimicrob. Chemother. 2005; 55(1): 115-8.

Higgins, P. G.; Poirel, L.; Lehmann, M.; Nordmann, P.; Seifert, H. OXA-143, a novel carbapenem-hydrolyzing class $\mathrm{D}$ beta-lactamase in Acinetobacter baumannii. Antimicrob. Agents Chemother, 2009 Dec, 53(12):5035-8.

Hussein, W. M.; Fatahala, S. S.; Mohamed, Z. M.; Mcgeary, R. P.; Schenk, G.; Ollis, D. L.; Mohamed, M. S. Synthesis and Kinetic Testing of Tetrahydropyrimidine-2-thione and Pyrrole Derivatives as Inhibitors of the Metallo- $\beta$-lactamase from Klebsiella pneumonia and Pseudomonas aeruginosa. Chem Biol Drug Des, 2012 Jun 27.

Jácome, P.R.L.; Alves, L.R.; Cabral, A.B.; Lopes, A. C.; Maciel, M.A.V. First report of KPC producing Pseudomonas aeruginosa in Brazil. Antimicrob. Agents Chemother. 2012 July.

Jeon, B. C.; Jeong, S. H.; Bae, I. K.; Kwon, S. B.; Lee, K.; Young, D.; Lee, J. H.; Song, J. S.; Lee, S. H. Investigation of a nosocomial outbreak of imipenemresistant Acinetobacter baumannii producing the OXA-23 beta-lactamase in Korea. J Clin Microbiol, 2005. 43(5):2241-5.

Jeong, S. H.; Lee, K.; Chong, Y.; Yum, J. H.; Lee, S. H.; Choi, H. J.; Kim, J. M.; Park, K. H.; Han, B. H.; Lee, S. W.; Jeong, T. S. Characterization of a new integron containing VIM-2, metallo- beta-lactamase gene cassette, in a clinical isolate of Enterobacter cloacae. J Antimicrob Chemother, 2003 Feb, 51(2):397400. 
Kim, SY.; Park, YJ.; Yu, JK.; Kim, HS.; Park, YS.; Yoon, JB.; Yoo, JY.; Lee, K. Prevalence and mechanisms of decreased susceptibility to carbapenems in Klebsiella pneumonia isolates. Diagn. Microbiol. Infect Dis. 2007 Jan; 51 (1): 85-91.

Kitao, T.; Akiyama, TM.; Tanaka, M.; Narahara, K. Development of na immunochromatografic assay for diagnosing the production of IMP type metallo$\beta$-lactamases that mediate carbapenem resistance in Pseudomonas.J. Microbiol. Methods. 2011, 330-337.

Kohler, T.; Michea-Hamzehpour, M.; Epp, S. F.; Pechere, J. C. Carbapenem activities against $P$ seudomonas aeruginosa: respective contributions of OprD and efflux systems. Antimicrob. Agents Chemother, 1999 Feb, 43(2):424-7.

Khosravi, Y. Loke, M. F.; Chua E. G.; Tay, S. T.; Vadivelu, J. Phenotypic Detection of Metallo- $\beta$-Lactamase in Imipenem-Resistant Pseudomonas aeruginosa. Scientific World J., 2012.

Kumarasamy, K. K. et al. Emergence of a new antibiotic resistance mechanism in India, Pakistan, and the UK: a molecular, biological, and epidemiological study. Lancet Infect, 2010.

Laraki, N.; Franceschini, N.; Rossolini, G. M. Biochemical characterization of the Pseudomonas aeruginosa 101/1477 metallo- $\beta$-lactamase IMP-1 produced by Escherichia coli. Antimicrob. Agents Chemother, 1999, (43): 902-906.

Lascols, C.; Hackel, M.; Hujer, A. M.; Marshall, S. H.; Bouchillon, S. K.; Hoban, D. J.; Hawser, S. P.; Badal, R. E.; Bonomo R. A. Using Nucleic Acid Microarrays To Perform Molecular Epidemiology and Detect Novel__Lactamases: a Snapshot of Extended-Spectrum_-Lactamases throughout the World $\mathbf{J}$. of Clin. Microbiology, May 2012, v.50, n. 5, p. 1632-1639.

Lauretti, L.; Riccio, M. L. et al. Cloning and characterization of bla vIM, a new integron-borne metallo- $\beta$-lactamase gene from a Pseudomonas aeruginosa clinical isolate. Antimicrob Agents Chemother, 1999, (43): 1548 -1590. 
Lee, B. K.; Chong, Y.; Shin, H. B.; Kim, Y. A.; Yong, D.; Yum, J. H. Modified Hodge and EDTA-disk synergy tests to screen metallo- $\beta$-lactamase-producing strains of Pseudomonas and Acinetobacter species. European Society of Clin. Microbiol. an Infectious Dis, 2001, 7:88-102.

Lee, K. et al. bla VIM-2 Cassete -Containing Novel Integrons in Metallo- $\beta$ Lactamase-Producing Pseudomonas aeruginosa and Pseudomonas putida Isolates Disseminated in a Korean Hospital. Antimicrob. Agents Chemoter, 2002 Apr, 1053-1058.

Lee, J. Y.; ko, K. S. OprD mutations and inactivation, expression of efflux pumps and $\mathrm{AmpC}$, and metallo- $\beta$-lactamases in carbapenem-resistant Pseudomonas aeruginosa isolates from South Korea. Int J Antimicrob Agents, 2012 Aug, 40(2):168-72.

Lee, K. et al. Improved performance of the modified Hodge test with MacConkey ágar for screening carbapenemase-producing Gram-negative bacilli. J. Microbiol. Methods, 2010, 83:149-152.

Levin, A. S.; Mendes, C. M.; Sinto, S. I.; Sader, H. S.; Scarpitta, C. R.; Rodrigues, E.; Sauaian, B. M. An outbreak of multiresistant Acinetobacter baumanii in a university hospital in Sao Paulo, Brasil. Infect. Control. Hosp. Epidemiol, 1996 Jun, 17(6):366-8.

Limansky, A.S; Mussi, MA; Viale AM. Loss of a 29-kilodalton outer membrane protein in Acinetobacter baumannii is associated with imipenem resistance. $\mathbf{J}$. Clin. Microbiol, 2002; 40 (12): 4776-8.

Lincopan, N. E. H; Mamizuka, E. M. Resistência bacteriana a antibióticos. Antibióticos na Prática Médica, 2007, 6 ed. São Paulo: Sarvier Ed. V.1, p. 4367.

Livermore, D. M. Multiple mechanisms of antimicrobial resistance in Pseudomonas aeruginosa: our worst nightmare? Clin Infect Dis, 2002, (34): 634-640. 
Machado, G.; Lago, A. et al. Occurrence and the susceptibility to antimicrobial agents in Pseudomonas aeruginosa and Acinetobacter sp. at a tertiary hospital in southern Brazil. Revista da Sociedade Brasileira de Medicina Tropical, marabr 2011, 44(2):168-172.

Marchand, I.; Damier- Piolle, L.; Courvalin, P.; Lambert, T. Expression of the RND Type Efflux Pump AdeABC in Acinetobacter baumannii is Regulated by the AdeRS Two-Component System, 2004, 48 (9): 3298-3304.

Marra, A.; Camargo, L.; Pignatari, A. et al. Nosocomial Bloodstream Infections in Brazilian Hospitals: Analysis of 2,563 Cases from a Prospective Nationwide Surveillance Study. J. Clin. Microbiol., 2011, 49: 1866-71.

Mausner, J.; Bahner, A. Epidemiology. Philadelphia, WB Saunders, 1974.

Mendes, R. E.; Castanheira, M.; Pignatari, A. C.; Gales, A. C. Metalo- $\beta-$ lactamases. J. Bras. Med. Lab., 2006; 42(2): 103-113.

Mendes, R.E., Kiyoya, K. A., Monteiro, J., Castanheira, M., Andrade, S. S., Gales, A. C., Pignatari, A. C.C \& Tufik, S. Rapid detection and identification of metallo- $\beta$-lactamase encoding genes by multiplex real-time PCR assay melt curve analysis. J. Clin. Microbiol., 2007, 45: 544-574

Migliavacca, R. et al. Simple Microdilution test for detection of metallo- $\beta$ lactamase production in Pseudomonas aeruginosa. J. Clin. Microbiol., 2002, 40: 4388-90.

Monteiro, J.; Santos, A. F.; Asensi MD, P. G.; Gales, A. C. First report of KPC-2producing Klebsiella pneumoniae strains in Brazil. Antimicrob Agents Chemother., 2009, 53(1):333-4.

Mostachio, A. K.; Van Der Heidjen, I.; Rossi, F.; Levin, A. S.; Costa, S. F. Multiplex PCR for rapid detection of genes encoding oxacillinases and metallobeta-lactamases in carbapenem-resistant Acinetobacter spp. J Med Microbiol., 2009 Nov, 58(Pt 11):1522-1524. 
Mostachio, A.K.; Levin, A.S.; Rizek, C.; Rossi, F.; Zerbini, J.; Costa, S.F. High prevalence of OXA-143 and alteration of outer membrane proteins in carbapenem-resistant Acinetobacter spp. isolates in Brazil. Int J Antimicrob Agents. 2012 May;39(5):396-401

Murray, C. K.; Hospenthal, D. R. Acinetobacter infection in the ICU. Crit Care Clin., 2009; 24: 237-48.

Murray, P. R.; Baron, E. J.; Tenover, F. C.; Yolken, R. H. Manual of clinical Microbiology. $8^{\text {nd }}$ ed. Washington DC: American Society for Microbiology; 2003. Cap.47, p. 719-25: Pseudomonas.

National Committee For Clinical Laboratory Standards. Development of In Vitro Susceptibility Testing Criteria and Quality Control Parameters: Approved Standard NCCLS M23-A2. NCCLS, Wayne, PA, USA, 1981.

National Committee For Clinical Laboratory Standards. Methods for dilution antimicrobial susceptibility test for bacteria that grow aerobically, 5th ed. Approved standard M7-A5. NCCLS, Wayne, Pa., 2002.

Nemec, A.; Musilek, M.; Maixnerová, M.; De Baere, T.; Van Der Reijden, T. J.; Vannechoutte, M.; Dijkshoorn, L. Acinetobacter beijerinckii sp. Nov. and Acinetobacter gyllenbergii sp. Nov., haemolytic organisms isolated from humans. Int J Syst Evol Microbiol, 2009 Jan, 59 (Pt 1): 118-24.

Neves, P.; Mamizuka, E.M.; Levy, C.E.; Lincopan, N. Pseudomonas aeruginosa multirresistente: um problema endêmico no Brasil. J. Bras. Patol. Med. Lab. 2011, 47 (4):409-420.

Nikaido, H. Porins and specific diffusion channels in bacterial outer membranes. J. Biol Chem., 1994, (269): 3905-3908.

Nordmann, P.; Poirel, L. ; Carrer, A. et al. How to detect NDM-1 producers. J. Clin. Microbiol., 2011, 49: 718-21. 
Okamoto, K.; Gotoh, N.; Nishino, T. Pseudomonas aeruginosa reveals high intrinsic resistance to penem antibiotics:penem resistance mechanisms and their interplay. Antimicrob Agents Chemother., 2001 Jul, 45(7):1964-71.

Okamoto, K.; Gotoh, N.; Nishino, T. Alterations of susceptibility of Pseudomonas aeruginosa by overproduction of multidrug efflux systems, MexAB-OprM, MexCD-OprJ, and MexXY/OprM to carbapenems: substrate specificities of the efflux systems. J. Infect Chemother., 2002 Dec, 8(4):371-3.

Paez, J.; Levin, A.; Fu, L. Clusters of infection due to metallo-blactamaseproducing Pseudomonas aeruginosa in stem cell transplant and haematology units. Journal of Hospital Infection., 2011, 77 () 76-92.

Peleg, A. Y.; Seifert, H.; Paterson, D. Acinetobacter baumannii: Emergence of a successful pathogen. Clin. Microbiol. Rev., 2008, 21 (3): 538-82.

Pellegrino, F. L.; Netto-Dos Santos, K. R.; Riley, L. W.; Moreira, B. M. BlaGES carrying Pseudomonas aeruginosa isolates from a public hospital in Rio de Janeiro, Brazil. Braz J Infect Dis., 2006 Aug, 10(4):251-3.

Pfeifer Y, W. G. et al. Molecular characterization of blaNDM-1 in an Acinetobacter baumannii strain isolated in Germany in 2007. J Antimicrob Chemother, 2011, 66: 1998-2001.

Picão, R. C.; Poirel, L.; Gales, A. C.; Nordmann, P. Diversity of beta-lactamases produced by ceftazidime-resistant Pseudomonas aeruginosa isolates causing bloodstream infections in Brazil. Antimicrob Agents Chemother., 2009 Sep, 53(9):3908-13.

Poirel, L. et al. Genetic support and diversity of acquired extended-spectrum blactamases in Gram-negative rods Infection, Genetics and Evolution, 2012, 12 883-893. 
Pournaras, S.; Markogiannakis, A.; Ikonomidis, A.; Kondyli, L.; Bethimouti, K.; Maniatis, A. N.; Legakis, N. J.; TSAKRIS, A. Outbreak of multiple clones of imipenem-resistant Acinetobacter baumannii isolates expressing OXA-58 carbapenemase in an intensive care unit. J Antimicrob Chemother, 2006 Mar, 57(3):557-61.

Qi, C.; Malczynski, M.; Parker, M.; Scheetz, M. H. Characterization of genetic diversity of carbapenem-resistant Acinetobacter baumanii clinical strains colleted from 2004 to 2007. J. Clin Microbiol,. 2008 Mar, 46 (3): 1106-9. Epub 2008 Jan 23.

Queenan, A. M.; BUSH, K. Carbapenemases: the versatile _-lactamases.Clin. Microbiol. Rev., 2007, 20:440-458.

Robledo, I. E.; Aquino, E. E.; Santé, M. I.; Santana, J. L.; Otero, D. M.; León, C. F.; Vázquez, G. J. Detection of KPC in Acinetobacter sp. in Puerto Rico. Antimicrob Agents Chemother, 2009.

Sader, H. S.; Castanheira, M.; Mendes, R. E.; Toleman, M.; Walsh, T. R.; Jones, R. N. Dissemination and diversity of metallo-beta-lactamases in Latin America: report from the SENTRY Antimicrobial Surveillance Program. Int J Antimicrob Agents, 2005 Jan, 25(1):57-61.

Sader, H. S.; Mendes, C. F.; Pignatari, A. C.; Pfaller, M. A. Use of macrorestriction analysis to demonstrate interhospital spread of multiresistant Acinetobacter baumannii in São Paulo, Brazil. Clin Infect Dis., 1996 Sep, 23(3):631-4.

Sader, H. S.; Reis, A. O.; Silbert, S.; Gales, A. C. IMPs, VIMs and SPMs: the diversity of metallo-beta-lactamases produced by carbapenem-resistant Pseudomonas aeruginosa in a Brazilian hospital. Clin Microbiol Infect., 2005 Jan, 11(1):73-6. 
Schereckenberger, P. C.; Daneshvar, M. L.; Weyant, R. S.; Hollis, D. G. Acinetobacter, Achromabacter, Chryseobacterium, Moraxella, and other nofermentative gram-negative rods. In: Murray, P.R.; Baron, E.J.; Jorgensen, J. H.; Pfaller, M.A.; Yolken, R. H. Manual of clinical Microbiology. $8^{\text {th }} \mathrm{ed}$. Washington, DC, ASM press, 2003, p.749-51.

Segal, H.; Elisha, BG.; Use of Etest MBL strips for the detection of carbapenenmases in Acinetobacter baumannii. J. Antimicrob. Chemother. $2005 ; 26$ July.

Senda, K. et al. PCR detection of metallo- $\beta$-lactamase Gene (bla $\left.\right|_{\text {IMP }}$ ) in Gramnegative rods resistant to broad-spectrum $\beta$-lactamase. J. Clin. Microbiol., 1996, 34: 2909-13.

Shibata, N.; Doi, Y.; Yamane, K.; Yagi, T.; Kurokawa, H.; Shibayama, K.; Kato, H.; Kai, K.; Arakawa, Y. PCR typing of genetic determinants for metallo-beta lactamases and integrases carried by gram-negative bacteria isolated in Japan, with focus on the class 3 integron. J Clin Microbiol., 2003 Dec, 41(12):5407-13.

Tenover, F.C.; Arbeit, R.D.; Goering, R.V. How to select and interpret molecular strain typing methods for epidemiological studies of bacterial infections: a review for healthcare epidemiologists. Molecular Typing Working Group of the Society for Healthcare Epidemiology of America. Infect Control Hosp Epidemiol., 1997, 18(6): 426-39.

Tognim, M. C.; Gales, A. C.; Penteado, A. P.; Silbert, S.; Sader, H. S. Dissemination of IMP-1 metallo- beta -lactamase-producing Acinetobacter species in a Brazilian teaching hospital. Infect Control Hosp Epidemiol., 2006 Jul, 27(7):742-7.

Toleman, M. et al. Molecular characterization of SPM-1, a novel metalo- $\beta$ lactamase isolated in Latin America: report from the SENTRY antimicrobial surveillance programme. J. Clin. Microbiol., 2002, 50: 673-9. 
Trabulsi, L. R.; Altherthum, F.; Gompetz, O. F.; Candelas, J. A. N. Microbiologia. 4a ed. São Paulo: Atheneu, 2003. Cap. 49, p. 359-68: Pseudomonas aeruginosa.

Tsakris, A.; Kristo, I. et al. Evaluation of Boronic Acid Disk Tests for Differentiating KPC- Possessing Klebsiella pneumoniae Isolates in the Clinical Laboratory. J. Clin. Microbiol., 2009, 47: 362-67.

Turton, J. F.; Ward, M. E.; Woorford, N.; Kaufmann, M. E.; Pike, R.; Livermore, D. M.; Pitt, T. Teh role of ISAba-1 in expression of OXA carbapenemase genes in Acinetobacter baumannii. FEMS Microbiol Lett., 2006, 258: 72-77.

Van Der Bij, A. K.; Mol, M.; Van Westreenen, M.; Goessens, W. H.; Pitout, J. D. The laboratory diagnosis of Pseudomonas aeruginosa that produce metallo- $\beta$ lactamases in a Dutch tertiary care centre. Scand J Infect Dis., 2011 Aug, 43(8):596-602.

Vella, P.; Hussein, W. M.; Leung, E. W.; Clayton, D. et al. The identification of new metallo- $\beta$-lactamase inhibitor leads from fragment-based screening. Bioorg Med Chem Lett., 2011 Jun 1, 21(11):3282-5.

Vila, J.; Martí, S.; Sánchez-Céspedes, J. Porins efflux pumps and multidrug resistance in Acinetobacter baumannii. J. Antimicrob. Chemother., 2007 Jun, 59(6): $1210-5$.

Villegas, M. L. K. et al. First Identification of Pseudomonas aeruginosa Isolates Producing a KPC- Type Carbapenem - Hydrolyzing $\beta$ - Lactamase. Ant. Ag. Chemo., 2007, 51 (4): 1553-55.

Von Dolinger De Brito, D.; Oliveira, E. J.; Abdallah, V. O.; Da Costa Darini, A. L.; Filho, P. P. Na oubreak of Acinetobacter baumannii septicemia in a neonatal intensive care unit of a universiity hospital in Brazil. Braz J Infect Dis., 2005, 9 (4): 301-9.

Walsh, T. et al. Evaluation of a New Etest for detecting metalo- $\beta$-lactamase in routine clinical testing. J. Clin. Microbiol., 2002, 40: 2755-9. 
Walther -Rasmussen, J.; Hoiby, N. Class A carbapenemases. Journal of Antimic Chemo., 2007, 60 (3): 470-482.

Walther-Rasmussen, J.; Hoiby, N. Oxa-type carbapenemases. J. Antimicrob. Chemother., 2006, 57: 373-383.

Wisplinghoff, H.; Schmitt, R.; Wohrmann, A.; Stefanik, D.; Seifert, H. Resistance to disinfectants in epidemiologically defined clinical isolates of Acinetobacter baumannii. J. Hosp. Infection, 2007, 66:174.

Woodford, N., Ellington, M. J., Coelho, J. M., Turton, J. F., Ward, M. E., Brown, S., Amyes, S. G. B. \& Livermore, D. M. Multiplex PCR for genes encoding prevalent OXA carbapenemases in Acinetobacter spp. Int J Antimicrob Agents, 2006, 27, 351-353.

Yang, SC.; Chang, W.J.; Chang, Y.H.; Tsai, Y.S.; Yang, T.P.; Juan, C.W.; Shiau, M.Y. Prevalence of antibiotics resistance and OXA carbapenemases genes in multidrug-resistance Acinetobacter baumannii isolates in central Taiwan. Eur. J. Clin. Microbiol. Infect. Dis. 2010, Jan 5.

Yigit, H.;Queenan, A.; Anderson, GJ.; Domenech-Sanchez, A.; BIDDLE, JW.; Steward, CD.; Alberti, S.; Bush, K.; Tenover, FC. Novel carbapenem-hydrolyzing blactamase, KPC-1, from a carbapenem-resistant strain of Klebsiella pneumoniae. Antimicrob Agents Chemother. 2001, 45:1151-1161. 
ANEXO 
Anexo I - Sensibilidade e especificidade dos métodos fenotípicos para detecção de carbapenemases em isolados clínicos de Acinetobacter spp. e $P$. aeruginosa.

\begin{tabular}{|c|c|c|c|c|c|c|c|c|}
\hline & \multirow[t]{2}{*}{ Resultados } & \multicolumn{2}{|c|}{$\begin{array}{c}\text { Aproximação } \\
\text { com IMP (DDST) }\end{array}$} & \multicolumn{2}{|c|}{$\begin{array}{c}\text { Aproximação } \\
\text { com CAZ (DDST) }\end{array}$} & \multirow{2}{*}{$\begin{array}{l}\text { Diferença } \\
\geq 8 \mathrm{~mm} \\
\text { entre IMP } \\
\text { e IMPE }\end{array}$} & \multirow{2}{*}{$\begin{array}{l}\text { E-test } \\
\text { MßL }\end{array}$} & \multirow{2}{*}{ Hodge } \\
\hline & & EDTA & ABM & EDTA & ABM & & & \\
\hline \multirow{10}{*}{ 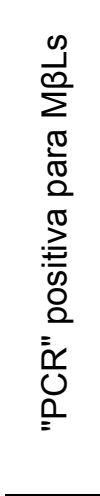 } & Acinetobacter spp. $(n=50$ & & & & & & & \\
\hline & Sensibilidade & $40 \%$ & $100 \%$ & $0 \%$ & $40 \%$ & $100 \%$ & $100 \%$ & $100 \%$ \\
\hline & Especificidade & $100 \%$ & $71 \%$ & $91 \%$ & $98 \%$ & $40 \%$ & $9 \%$ & $42 \%$ \\
\hline & Valor preditivo positivo & $100 \%$ & $28 \%$ & $0 \%$ & $66 \%$ & $16 \%$ & $11 \%$ & $16 \%$ \\
\hline & Valor preditivo negativo & $93 \%$ & $100 \%$ & $89 \%$ & $93 \%$ & $100 \%$ & $100 \%$ & $100 \%$ \\
\hline & $\begin{array}{l}\text { Pseudomonas aerugino } \\
(n=108)\end{array}$ & & & & & & & \\
\hline & Sensibilidade & $32 \%$ & $8 \%$ & $48 \%$ & $16 \%$ & $72 \%$ & $100 \%$ & $8 \%$ \\
\hline & Especificidade & $97 \%$ & $98 \%$ & $92 \%$ & $92 \%$ & $73 \%$ & $19 \%$ & $95 \%$ \\
\hline & Valor preditivo positivo & $80 \%$ & $50 \%$ & $67 \%$ & $40 \%$ & $44 \%$ & $27 \%$ & $33 \%$ \\
\hline & Valor preditivo negativo & $83 \%$ & $78 \%$ & $86 \%$ & $79 \%$ & $89 \%$ & $100 \%$ & $77 \%$ \\
\hline \multirow{5}{*}{ 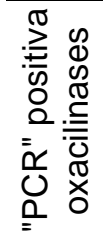 } & Acinetobacter spp. $(n=5$ & & & & & & & \\
\hline & Sensibilidade & $3 \%$ & $32 \%$ & $11 \%$ & $0 \%$ & $61 \%$ & $92 \%$ & $58 \%$ \\
\hline & Especificidade & $91 \%$ & $50 \%$ & $100 \%$ & $75 \%$ & $25 \%$ & $8 \%$ & $25 \%$ \\
\hline & Valor preditivo positivo & $50 \%$ & $67 \%$ & $100 \%$ & $0 \%$ & $72 \%$ & $76 \%$ & $71 \%$ \\
\hline & Valor preditivo negativo & $23 \%$ & $19 \%$ & $26 \%$ & $19 \%$ & $17 \%$ & $25 \%$ & $16 \%$ \\
\hline \multirow{5}{*}{ 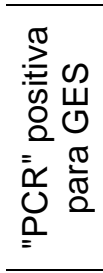 } & $\begin{array}{l}\text { Pseudomonas aerugino } \\
(n=108)\end{array}$ & & & & & & & \\
\hline & Sensibilidade & $0 \%$ & $0 \%$ & $25 \%$ & $25 \%$ & $0 \%$ & $75 \%$ & $25 \%$ \\
\hline & Especificidade & $90 \%$ & $96 \%$ & $83 \%$ & $91 \%$ & $61 \%$ & $14 \%$ & $95 \%$ \\
\hline & Valor preditivo positivo & $0 \%$ & $0 \%$ & $5 \%$ & $10 \%$ & $0 \%$ & $3 \%$ & $16 \%$ \\
\hline & Valor preditivo negativo & $95 \%$ & $96 \%$ & $97 \%$ & $96 \%$ & $94 \%$ & $94 \%$ & $97 \%$ \\
\hline
\end{tabular}


Anexo II

joumal of marpira insecoon $/ /$ (2011) $/ 0-Y 2$

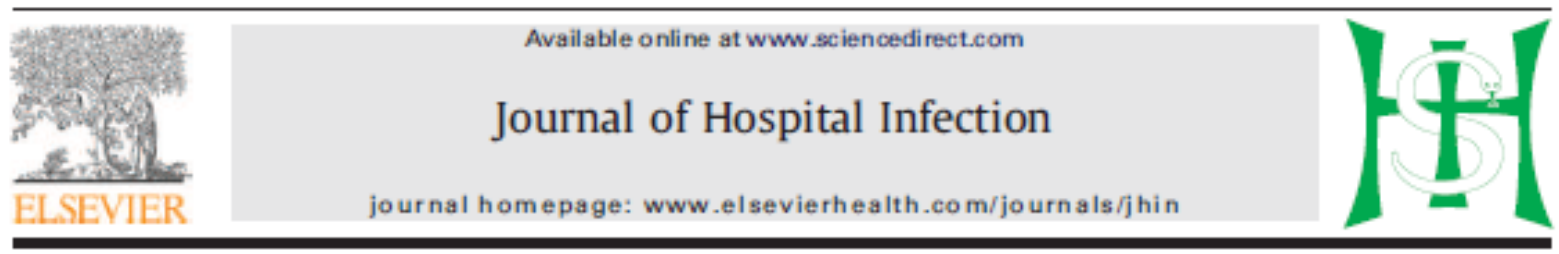

Letters to the Editor

Clusters of infection due to metallo- $\beta$-lactamaseproducing Pseudomonas aeruginosa in stem cell transplant and haematology units

Madam,

The prevalence of infection with carbapenem-resistant Pseudomonas aeruginosa has increased world wide. ${ }^{1-3}$ Metallo- $\beta$-lactamase (MBL) production is the most frequent mechanism of resistance. ${ }^{3-6}$ We describe two clusters of infection due to carbapenem-resistant $P$, aenuginosa that occurred in stem cell transplantation (SCT) and haematology units at a Brazilian teaching hospital over a period of four years.

A case was defined as a patient from whom carbapenemresistant $P$. aenuginosa was recovered from any infected site between January 2006 and March 2009. For each case we evaluated the following variables: age, underlying diseases, neutropenia central venous catheter, site of infection, unit of hospitalisation, length of hospital stay, use of carbapenem and colistin, treatment of $P$, aenginasa infection and outcome within 30 days of infection.

An automatic method (Vitek, bioMérieux, Marcy l'Etoile,France) was used for identification and susceptibility. Identification was confirmed using AP1 20NE (bioMérieux). Minimum inhibitory concentrations (MICs) for imipenem, meropenem and colistin were determined by broth microdilution, accord ing to Clinical Laboratory Standards Institute (CISI) guidelines Disc-approximation test with imipenem and ceftazidime in the presence of 2-mercaptopropionic acid (MPA), EDTA and MBLE-test wasemployed to screen for MBLs, SPM-1 producer $P$, aeruginosa (SP2432) was used as a control. PCR was used for detection of blas:M-1, bla $a_{\text {MM-1, }}$ blaMP-1 and int-1. The PCR fragments obtained were sequenced using the MegaBACE 1000 DNA Sequencer and compared with those in GenBank (data available online). Pulsed-field gel electrophoresis using Spe1 was interpreted according to Tenover et $a^{7}{ }^{7}$ When a cluster was identified, contact precautions were instituted. Education on hand hygiene and CVC care was reinforced by lectures attended by all healthcare workers. Alcohol hand rubs (one dispenseriroom) and one sink with a chlorhexid ine dispenser for every four rooms were available. CVC lines were covered with plastic during bathing and $0.5 \%$ ch brhexidine was used for CVC dressing

Thirteen patients presented with carbapenem-resistant $P$, aenuginosa infections, comprising two clusters: one in 2007 and one in 2009. All isolates had an MIC $\geq 128 \mathrm{mg} / \mathrm{L}$ of imipenem and meropenem, except one (MIC: $64 \mathrm{mg} / \mathrm{L}$ ). The isolates were susceptible only to colistin (MIC: $<0.25-2 \mathrm{mg} / \mathrm{L}$ ). MPA detected MBL in $500 \mathrm{~s}$ of cases, EDTA in $60 \%$ and E-test in $100 x$ Eleven isolates were positive for blasM and two for blavm. All 2007 isolates had an identical genotype (named A: eight isolates), whereas the 2009 isolates showed four different genotypes (named B-D; one isolate each). Clones A, B and D carried blaspM-I (GenBank accession number
AY341249) and clone C presented blavinz (AF191564). MM-2 was int-1 positive (AF263519).

Our high carbapenem MICs suggest the association of MBL with other mechanisms such as alteration of outer-membrane protein. SPM- 1 is the most common MBL in Brazil $^{3,68}$ Recently, the spread of an epidemic SPM-1-producing $P$. aenuginosa strain among B razilian hospitals was reported. ${ }^{36}$ SPM-1-producing $P$. aenuginosa in haematological patients was previously reported in Brazil, but this is the first outbreak due to SPM-1 and VIM-2 in SCT units in the country. ${ }^{3}$ VIM-2 was first reported in France. To date in Brazil there has only been one report of VIM-2 in which $300 \%$ of 36 MBL isolates were VIM-2 producers. $^{8}$

Carbapenems are widely used in the empiric treatment of febrile neutropenia, thus the risk of infection by carbapenem-resistant $P$. aeruginosa among this population is high ${ }^{12}$ In all, $92.3 \%$ of our patients had received carbapenems before the infection. Despite this fact, so far only two outbreaks due to VIM-2-produding $P$. aenuginosa have been reported in haematology units, both of these in France ${ }^{4.5}$ In contrast with our report, one of these outbreaks showed persistence of one genctype over 10 years. ${ }^{5}$ In our study we focused on simple infection control measures: rein forcement of hand hygiene and CVC care. These were sufficient to control both clusters. Most of our patients were neutropenic and almost 700 had undergone SCT, but our mortal ity was relatively low. This may be explained by the early empiric use of colistin among neutropenic febrile patients at risk for acquiring carbapenem-resistant $P$. aeruginosa in our hospital (contact with colonised/infected patients and severe neutropenia). Another interesting finding is that, despite the extensive use of empiric colistin, none of the strains was resișant Codistin is a useful antibiotic in the treatment of multidrug-resistant Gram-negative infections, but itseems appropriate to have criteria for its prescription in haematological patients in order to avoid the spread of resistance. Unfortunately this class is the last option to treat pan-resistant $P$. aeruginosa, with no new drugs in sight in the near future.

In conclusion, carbapenem-resistant $P$. aeruginosa is a problem among haematological patients as it entails high morbidity and mortality. VIM-2 was detected although SPM-1 is the predominant MBL in Brazil Simple measures such as rein forcement of hand hygiene and CVC care were sufficient to control the infections. Early empirical use of colistin in this scenario may be an interesting strategy.

\section{Conflict of interest statement}

None declared.

\section{Funding sources}

None

\section{References}

1. Habld M, Limaye AP, Kim HW, Nirby KA, Corey L, Boeckh M. Invas he Pseudomanas weruringa infections: high rze of recurrence and mortality a ter hem zopoiesc cell transplantzion. Bone Marnow Transpl 2007; 11:687-6ra. 


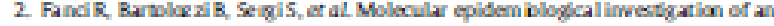

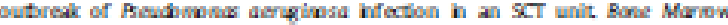
Thased 2000,4:335-338.

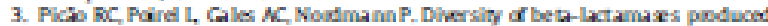

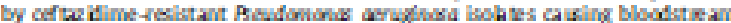

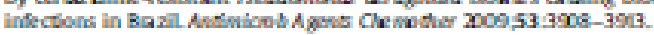

4. Aubran C, Poired L, Fartinede N, Nicolac P, Coller L, Noadmann P. Nowocomial

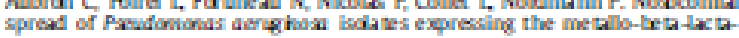

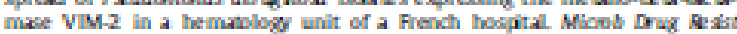
$2005,11254-29$.

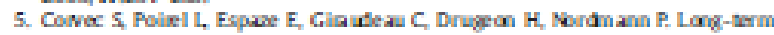

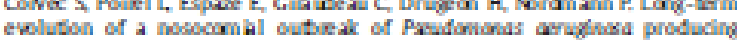
VM-2 metllb-encyme. / Hoxp Ifort 2008,68.73-82.

6. Gales $M C$, Menezes IC, Sibert S, Sader HS Dissemination in dstinct Bazillar.

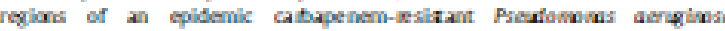

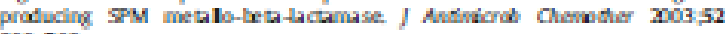
$602-702$

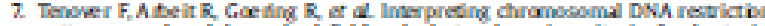
patrerns prodiced by pulised-field gel dectwophowsils cifterila for bacterial

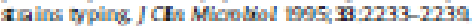

8. Sader HS Re is $A Q$ SilbertS, Sibert S, Gides MC MMPS, VMMsand SPMs: the diversity of merallo bert-lacta maes profuced by cartupene m-rexistant Prewdoninger

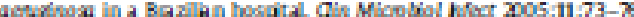

1. Paer AS. Levin

L Fu*

M. Basso:

G.H.H. Forsecad

F.L Dulley

F. Rossi"

T. Guimaraes

SF. Costa ${ }^{4 c *}$

Labaratary of Bacterialogy, Has pital das Cinicas University of São Paula, São Paula, Brazil

Infectian Control Committee, Haspital das Cinicas. University of São Paula, São Paula, Bazil

'Depar onent of Infectious Diseases, School of Medidine, Lhiversity of São Paula, São Paula, Brazil

${ }^{\mathrm{d}}$ Bane Marrow Transplant and Hemablogy Units, Haspinal das Clinicas, Lhiversity of São Paula, São Paula, Brazil

"Labara tory of Micrabialogy of Hospital das Clinicas, São Paulo, Brazil

- Corresponding author. Address: Laboratory of Bacteriology

(UM-54) of Hospital das Clinicas, University of Sio Paula

Av. Dr. Eneias Carvalho de Aguiar 255, Cerqueirq Cesar,

Sao Paulo 05403-900, Brazil Aax: +55 1130697066 .

E-mail address: costasilviafoig.com.br (S.E Costa).

Available online 27 October 2010

Q 2010 The Hospital Infection Society. Published by Esevier Ltd. All rights reserved.

doi:10.1016/j_.jhin_2010.08.007

Resistance rates of Pseudomonas aeruginos $a$ and Acinetobacter species causing ventilator-associated pneumonia do not always correlate with utilisation of antibiotics

Madam,

Numerous published studies have sought a correla tion between the utilisation rate of antibiotics and resistance rates among hospital isolates, but their results are not dear-cut. ${ }^{1}$ Some of the studies noticed a positive correlation between resistance rates of hospital isolates and the utilisation rates of ciprofloxacin, cepha losporins, carbapenems, piperacilin/tazobactam, or all of these ${ }^{2}$ However, there are studies which show no such correlation, especially for carbapenems, for ceftazidime and Pseudomanas aeruginosa, or for all classes of antibiotics administered as primary thera py in intensive care settings. ${ }^{2.3}$ Whende monstr ated, the influence of the increased utilisation of antibiotics on resistance rates is immediate for carbapenems penicillins and ephalosporins and with a lag of one year for ciprofloxacin, macrolides and aminoglycosides?

These differences are at least partially accounted for by the different prevalence of certain isolates for each study, which suggests that correlation between antibiotic utilisation and resistance is an isclate-dependent phenomenon. Therefore, we decided to compare utilisation of antibiotics used to treat ventila tor-associated pneumonia (VAP) caused by P. aenginasa (data not shown) or Acintebocter spp. (Figure 1), and the resistance rates of these two pathogens isolated at the intensive care unit, Clinical Center, Kragujevac, Serbia, during an 18-month period. The observation period was divided into three 6 -month intervak, and use of antibiotics eflective against $P$. aeruginosa and Acinebbacter spp. was monitored during the study period and also for the preceding 6 months. There were 10 isolates of $P$. aeruginosa and 12 isolates of Acineto bocter spp. during the first interval, 6 isolates of $P$. aenginas a and 4 isolates of Acinetb bocter spp. during the second interval, and 13 isolates of $P$. aeruginosa and 17 isolates of Adinetobacter spp. during the last 6-month interval (the isolates were obtained from samples taken by bronchoalveolar lavage from patients with VAP). The utilisation of antibiotics was expressed as number of defined daily doses per 100 patient-days, and the resistance rate as the percentage of resistant isolates.

Our data indicate that the resistance rates of both $P$. aeruginas $d$ and $A$ cinetobacter spp. to carbapenems does not follow the utilisation rateof these antibiotics. On theother hand, while the res istance rate of $P$. aeruginosa to cefepime and piperadllin-tazobactam appears to be related to the use of these two agents, this is not the case with Acinebbacter spp. Finally, the resistance rate of Adinetobocter spp. to ampicillin-sulbactam seems to relate to the use of this antibiotic.

Although antibiotic use is a very important factor in the selection of multidrug-resistant bacteria in intensive care units, it is not the only one. Increasing use of invasive interventions, inadequate maintenance of lygiene standards and inadequate use of disinfectants (e.g in hand disinfection) also play a significant role 2,4 Emergence of multidrug-resistant Acinebbacter spp. isclates is associated with mechanical ventilation, haemodialysis malignancies, neurological impairment, the isolation of Acinebbacter spp. from multiple anatomic sites, and resistance to multiple disinfectants. ${ }^{5-7}$ Adinetabacter spp induce weak inflammatory responses, and their presence in the tissues of infected patients is prolonged, which increases the chance of transmission from patient to patient. ${ }^{8}$ Therefore, our efforts to control the incidence of multidrug-resistant bacteria in hospitals should not be limited to improvement of antibiotic prescribing but should also include improvement of aseptic techniques in medical procedures judidious use of disinfectants and adequate maintenance of hygiene.

\section{Conflict of interest statement}

None decla red.

Funding sources

This work was partially financed by grant No. 145005 given by the Serbian Ministry of Science and Ecology. 